\title{
REFLECTIVE WRITING FOR A BETTER UNDERSTANDING OF SCIENTIFIC CONCEPTS IN HIGH SCHOOL
}

\author{
Joseph El-Helou
}

\author{
A Thesis in the \\ Department of Physics
}

\begin{abstract}
Presented in Partial Fulfillment of the Requirements for the Degree of Master of Science (Physics) At

Concordia University

Montreal, Quebec, Canada
\end{abstract}

August, 2016

(C) Joseph El-Helou, 2016 


\section{CONCORDIA UNIVERSITY School of Graduate Studies}

This is to certify that the thesis prepared

By: $\quad$ Joseph El-Helou

Entitled: $\quad$ Reflective writing for a better understanding of scientific concepts in high school and submitted in partial fulfillment of the requirements for the degree of MASTER OF SCIENCE (Physics)

complies with the regulations of the University and meets the accepted standards with respect to originality and quality.

Signed by the final examining committee:

Dr. V. Zazubovits

Prof. B. M. Shore

Dr. S. Misra

Dr. C. S. Kalman

Approved by

Chair of Department or Graduate Program Director

Dean of Faculty
Chair

Examiner

Examiner

Supervisor

Date 


\begin{abstract}
Reflective Writing for a Better Understanding of Scientific Concepts in High School
\end{abstract}

Joseph El-Helou

This study evaluates the impact reflective writing has on high school students' understanding of scientific concepts and their attitudes and opinions toward learning science. Reflective writing is a part of the writing-to-learn movement (Connolly, 1989), the aim of which is to incorporate informal writing into all disciplines. Reflective writing is a hermeneutic process during which a student writes, metacognitively on a paper, his or her ideas about a specific scientific topic, in an informal manner. The research done on the use and impact of Reflective Writing involved post-secondary students. This study aims to shed light on how reflective writing affects high school students' understanding of science. Participants in this study are high school students, from a Montreal school, who were asked to complete reflective writing tasks as a part of their science course work. Their writings are analyzed and compared to their attitudes and opinions toward the subject as probed by interviews conducted towards the end of the course. 


\section{ACKNOWLEDGMENTS}

I would like to express my sincere gratitude to my advisor Prof. Calvin Kalman for his guidance and motivation. I'm not the easiest of students and he made supervising me seem a breeze.

Besides my advisor, I would like to thank the rest of my thesis committee: Prof. Bruce M. Shore and Prof. Sushil Misra for their comments and encouragement. Their contributions added significant focus to my perspective of this study.

My sincere thanks to all the participants and the teachers who conducted the interviews for all the time and efforts they have invested in this study.

Last but not the least, I would like to thank my wife for her constant support and being parent to our three children during the times when I was mentally or physically absent. 


\section{TABLE OF CONTENTS}

List of figures .................................................................................................................. vii

List of tables................................................................................................... vii

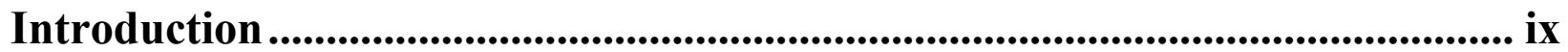

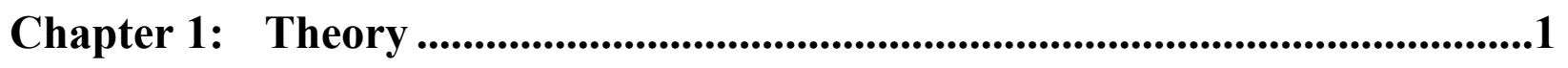

1.1 Theoretical framework: Hermeneutics ............................................................... 1

1.2 Hermeneutics and science education.................................................................... 7

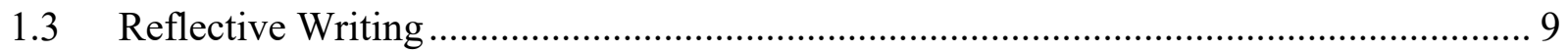

1.4 Reflective writing and classroom discussions (role of the teacher) .......................... 16

1.5 Reflective writing in high school science courses ................................................ 19

Chapter 2: Methodology …...........................................................................................21

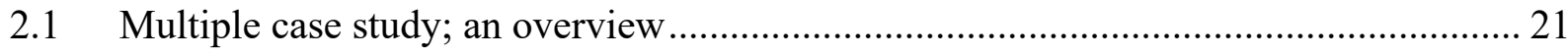

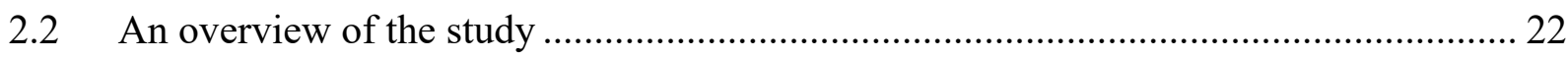

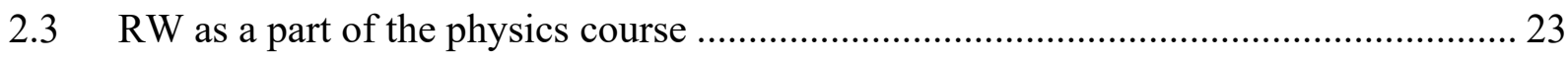

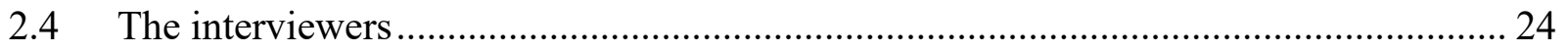

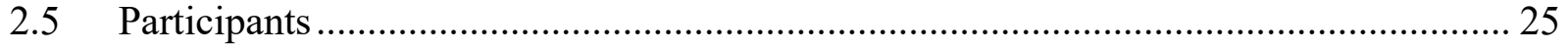

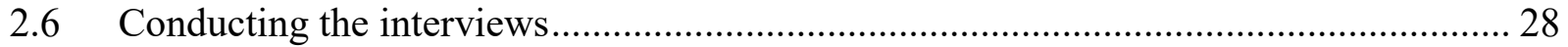

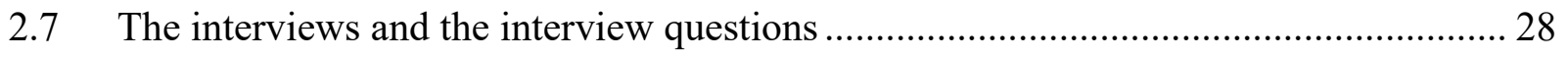

Chapter 3: Results .............................................................................................................30

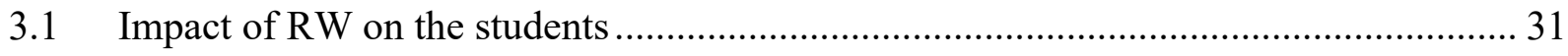

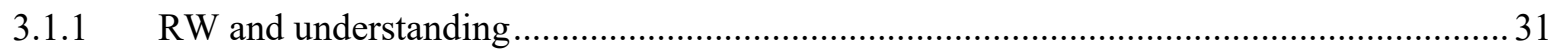

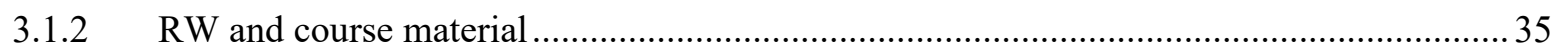

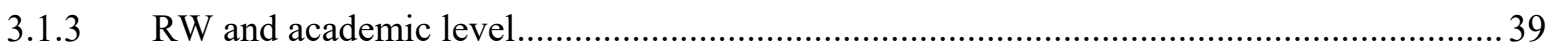

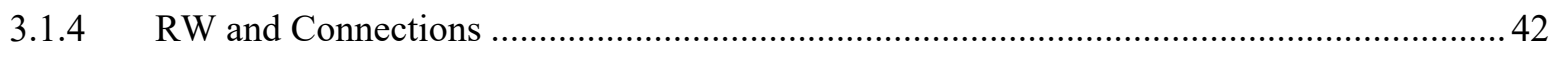

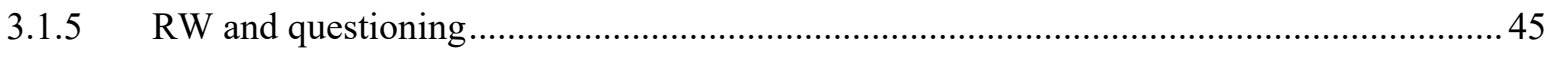

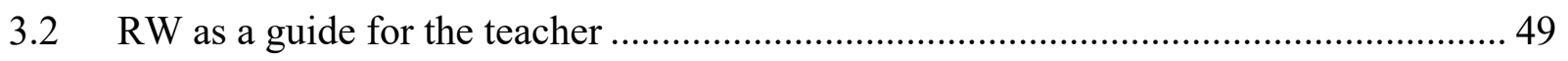

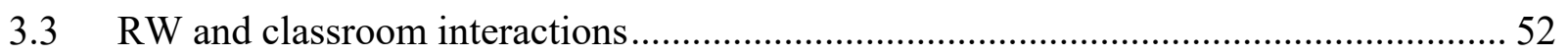


3.4 Evolution of how students completed the RW tasks........................................... 58

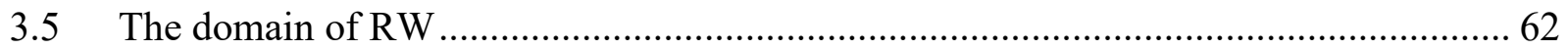

Chapter 4: Conclusion ..............................................................................65

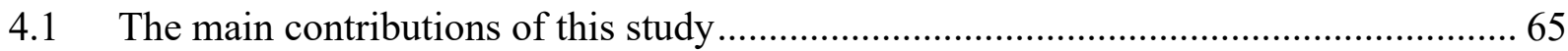

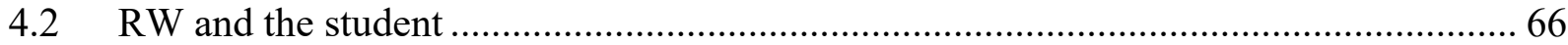

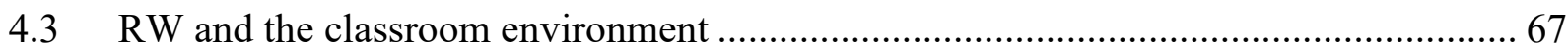

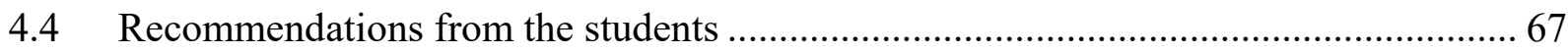

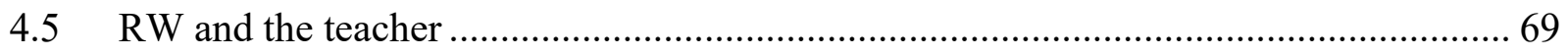

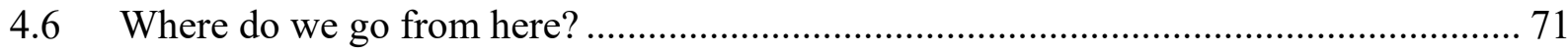

References

Appendix A ................................................................................................................81

Appendix B ........................................................................................................................83

Appendix C ...........................................................................................................................84

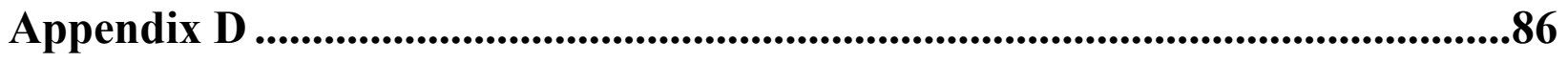

Appendix E ..........................................................................................................................88 


\section{LIST OF FIGURES}

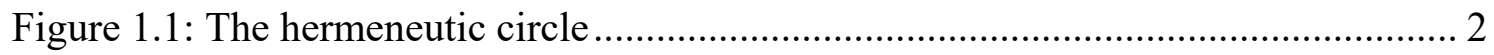

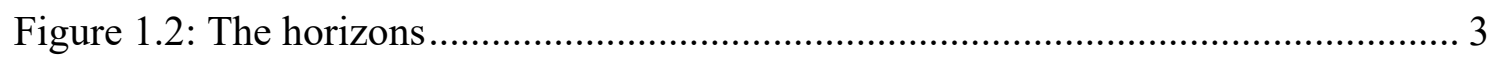

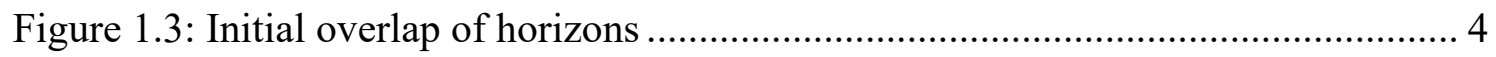

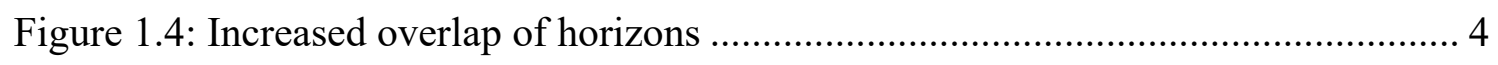

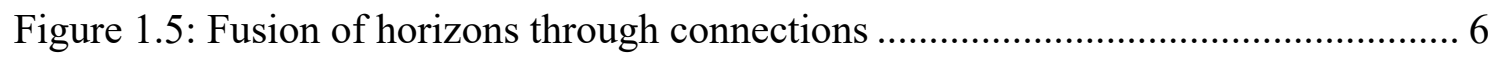




\section{LIST OF TABLES}

Table 1.1: Reflective Writing Rubric ....................................................................... 14 


\section{INTRODUCTION}

Reflective Writing (RW) is a tool designed to engage students, through writing tasks, in a process that helps them better understand science concepts. Before covering the material in class, the teacher would ask the students to read the material in their textbooks, as homework, then to write about what they have read. The students are asked to write, in an informal manner that resembles "free-writing”. Even though their writings are informal, they must include questioning as well as connections between the concepts they read about as well as connections between those concepts and their everyday lives. The teacher gets the chance to go over their writings before engaging the material in class, where their ideas about the material will be the topic of classroom discussions. For a teacher, it is a simple tool yet amazingly effective.

RW already left its mark, and continues to do so, on postsecondary students (Kalman, 2011). Most, if not all the research, on RW targeted postsecondary students. This study evaluated the impact of RW, followed by classroom discussions, on secondary students. Particularly this study evaluated the impact of RW on students with different academic levels (A, B and Cstudents). Results corroborated and expanded previous outcomes form studies conducted with postsecondary students. Differences were detected in the attitudes of students of different academic levels toward RW as well as in the way they were impacted by it. This study also showed that administering RW to secondary students must be adjusted to their particular circumstances when one compares them to those of postsecondary students. 
Participants to this study were high school students in the Montreal area who completed RW tasks as a part of their Physics course. Their writings were analyzed and their opinions and attitudes were probed by interviews at the end of the course.

In the first section of chapter one, hermeneutics is presented as the theoretical framework of RW. A literature review that situates RW and classroom discussions is provided in the subsequent sections. Chapter 2 covers the methodology of this multiple case study. In the third chapter results are presented and in the fourth conclusions are drawn and recommendations are made.

Throughout my 21 years teaching experience I grew more appreciative of the simple methods that are easy to apply and that make the teacher's job easier. One of my favourites is to engage students in a reflective thinking process during the classroom discussions. During this process, the students are lead to think about their Physics knowledge and how their knowledge is interconnected. They are also lead to relate what they know of physics to their everyday lives and vice-versa.

Professor Calvin Kalman introduced RW. It is much more efficient than reflective thinking. By reflectively writing, students do reflective thinking in a more thought-out way. RW did not replace classroom discussions, it made them better, too. 


\section{Chapter 1: $\quad$ Theory}

This chapter covers the theoretical tenets of the study. It introduces Hermeneutics as the theoretical framework of Reflective Writing (RW) and how science education has benefited from the hermeneutic approach. In the third section, the importance of classroom discussions that followed RW is highlighted. The last section situates this study as a valuable contribution to the work already completed with RW and how it extends it to high school students.

\subsection{Theoretical framework: Hermeneutics}

"Hermeneutics" comes from the Greek verb "hermeneuein", which means "to interpret" or "to translate". Hermeneutics can be traced back as far as the ancient Greeks (Porter \& Robinson, 2011). Porter and Robinson describe hermeneutics "in its most basic sense" as: "the many ways in which we may theorize about the nature of human interpretation, whether that means understanding books, works of art, architecture, verbal communication, or even nonverbal bodily gestures" (p. 1). At one time, hermeneutics was the process used to interpreting ancient text. The key process through which text is interpreted is known as the hermeneutic circle (Figure 1.1). Friedrich Ast (1778-1841) was probably the first to draw attention to the circularity of interpretation: "The foundational law of all understanding and knowledge", he claimed, is "to find the spirit of the whole through the individual, and through the whole to grasp the individual" (Ast, 1808, p. 178). The hermeneutic circle is based on the idea that to understand a text, one must understand its parts and the parts are only understood through their relation to the whole text. Understanding a part of the text can only be achieved with respect to the text as a whole. As 
well as understanding the whole of the text can only be achieved through the understanding of its parts.

With every run of the circle, a reader improves his or her understanding of the text. However it is likely that through use of the hermeneutic circle a text cannot be fully understood, one can only improve understanding without really totally achieving it.

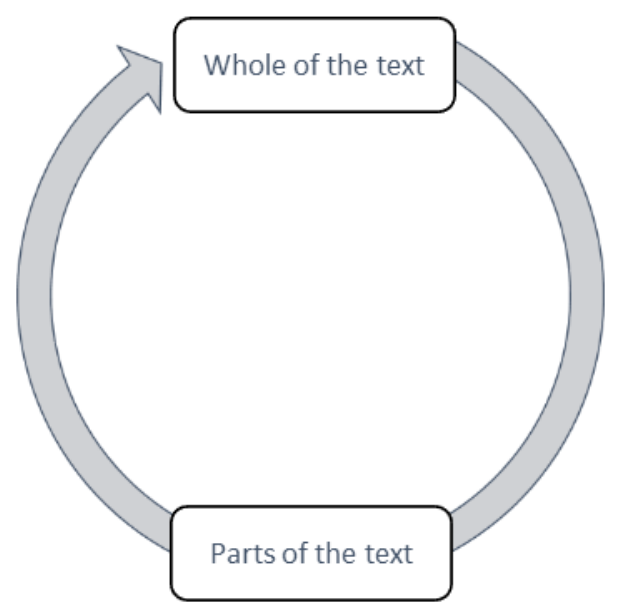

Figure 1.1: The hermeneutic circle

Friedrich Schleiermacher (1768-1834), hailed hermeneutics as a universal discipline, one which applies equally to all subject-areas (e.g. the bible, law, and literature), to oral as well as to written language, to modern texts as well as to ancient (Forster, 2009). In a lecture of 1829, Schleiermacher adopts the hermeneutic circle as a principle of hermeneutics (Schleiermacher \& Frank, 1977).

In 1960, Georg Hans Gadamer introduced the modern theory of hermeneutics in his book Truth and Method (Gadamer, 2004). His approach to hermeneutics is known as "Philosophical Hermeneutics". Gadamer again emphasized the role of the hermeneutic circle in understanding: "The anticipation of meaning in which the whole is envisaged becomes actual understanding when the parts that are determined by the whole themselves also determine this whole"(Gadamer, 2004, p. 291). Gadamer described understanding as the intersection of two 
horizons: the horizon of the text and that of the reader. In the context of this study, the text is a scientific text found in textbooks and the reader is a student (Figure 1.2)

A horizon is: "the range of vision that includes everything that can be seen from a particular vantage point" (Gadamer, 2004, p. 301). The horizon of the reader has dynamic boundaries that are determined and evolve with the knowledge, lived experience and skill set of the reader. The horizon "encloses the field of meanings that our various pre-conceptions, tacit

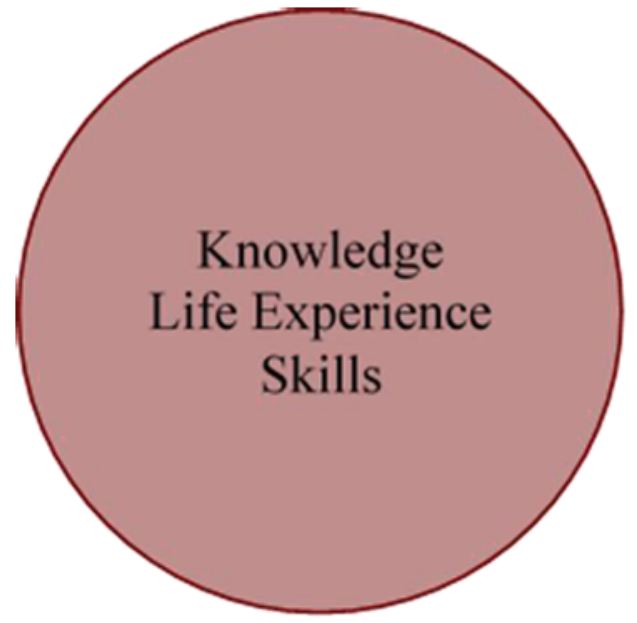

Student's horizon

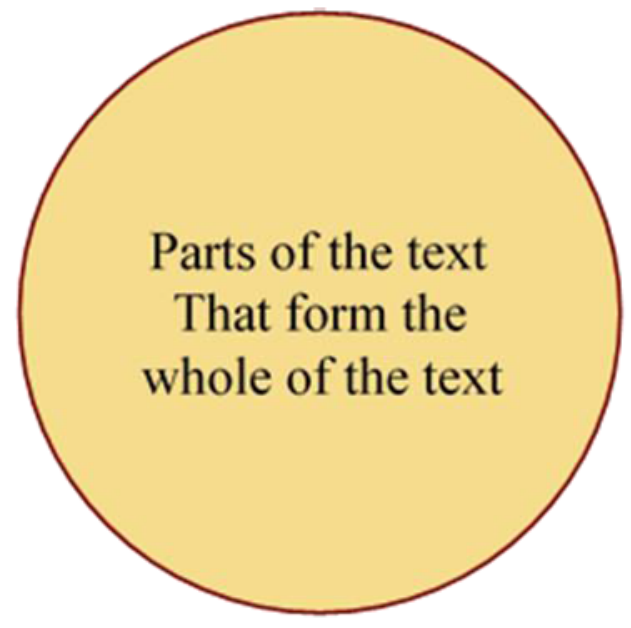

Text's horizon

Figure 1.2: The horizons

and otherwise, allow us at any given time. It defines, in other words, both our grasp and our limitations" (Eger, 1993a, p. 14). A student must start somewhere to obtain meaning. Hence preconceptions, even if "wrong", give students a starting point. Gadamer (2004) highlighted this idea: "Interpretation begins with fore-conceptions that are replaced by more suitable ones" (Gadamer, 2004, p. 269) The other horizon is that of the text, "the text we are trying to interpret also has its horizon: a limit to all those meanings to which a text of this sort, employing a language of this sort, possibly could give rise"(Eger, 1993a, p. 14). If the student's horizon and the text's horizon do not overlap at all, there is no way for the projections of the student to fall within the realm of the text's potential meanings, and the attempt to reach understanding fails. If, 


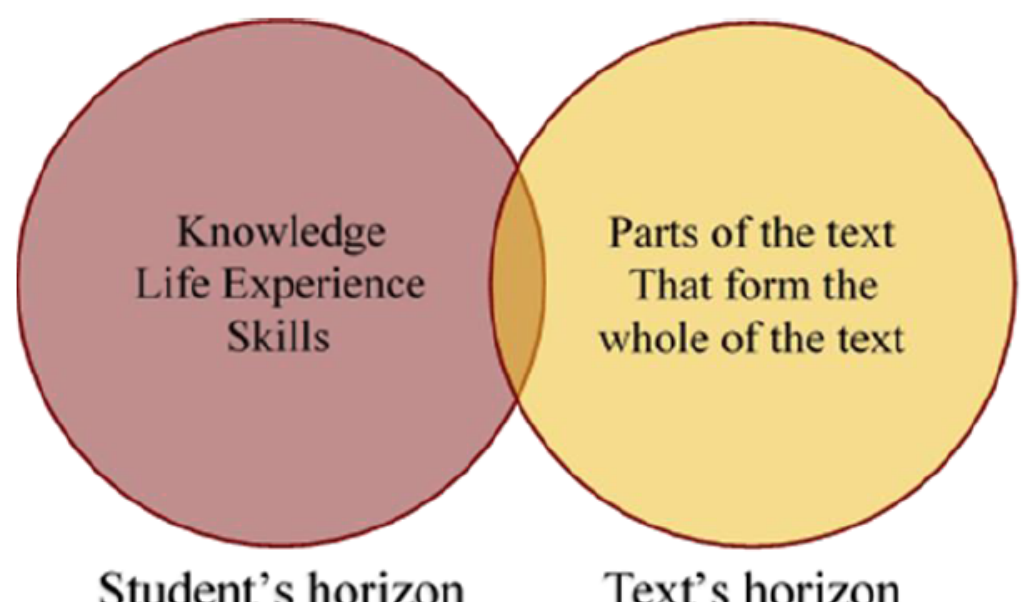

Figure 1.3: Initial overlap of horizons

on the other hand, an overlap does exist (Figure 1.3), this means that the students recognized parts of the text. Starting with the recognized parts, the student goes through the back-and-forth movement of interpretation, through the hermeneutic circle, between the parts of the text and the whole of the text, which permits the student to traverse the horizon of the text and move deeper into its language domain (Eger, 1993a). This would expand the student's field of vision, which would increase the student's recognition of the parts of the text. This increase of recognition leads to an increase in the overlap of both horizons (Figure 1.4) to a point where the two

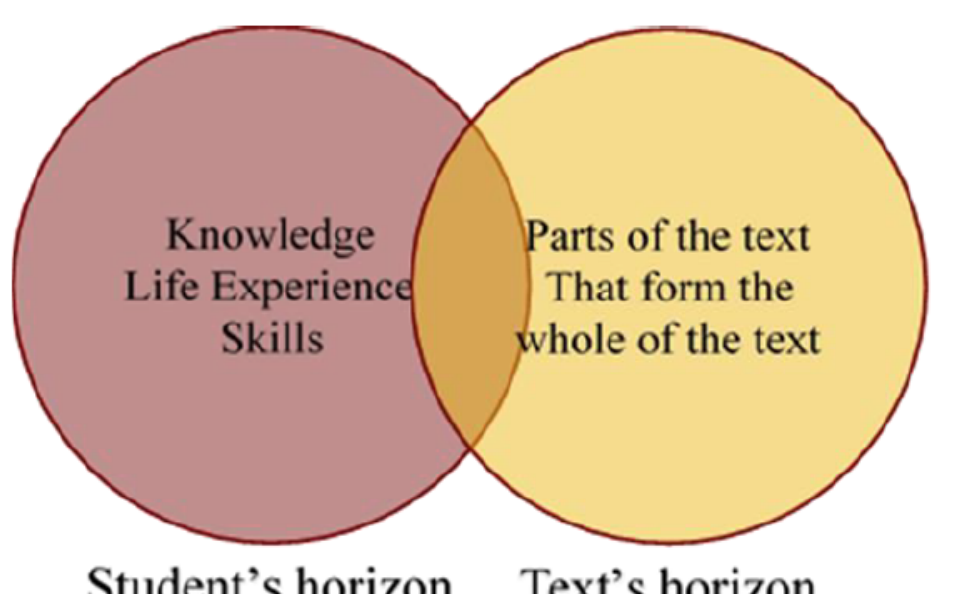

Figure 1.4: Increased overlap of horizons 
horizons can be said to have 'fused'. When this occurs, we have the supreme moment of understanding (Gadamer, 1975, pp. 269-273).

Hermeneutics extends far beyond the scope of this study. However, we would like to highlight two of its aspects that hold a special significance to the use of RW. The first one is questioning and the second one is connections (or relations, bonds, links). RW (discussed in section 1.3) is designed to trigger questioning and target connections. According to Gadamer, understanding (text in particular) occurs with the "fusion of horizons" as a result of the reader (the student) being engaged in a hermeneutic circle. Gadamer repeatedly emphasized the central role that questioning plays in the back-and-forth process of the hermeneutic circle. "Interpretation is a circle closed by the dialectic of question and answer" (Gadamer, 2004, p. 391). "Thus a person who wants to understand must question what lies behind what is said. He must understand it as an answer to a question" (Gadamer, 2004, p. 363). "The essence of the question is to open up possibilities and keep them open" (Gadamer, 2004, p. 298).

In numerous parts of his book, Gadamer also emphasized the essential role of connections in the process of understanding. "Hermeneutics must start from the position that a person seeking to understand something has a bond to the subject matter that comes into language through the traditionary text and has, or acquires, a connection with the tradition from which the text speaks" (Gadamer, 2004, p. 295). "It [understanding] implies the general possibility of interpreting, of seeing connections, of drawing conclusions, which constitutes being well versed in textual interpretation." (Gadamer, 2004, p. 251). "Understanding begins... when something addresses us. This is the first condition of hermeneutics" (Gadamer, 2004, p. 298). For Gadamer, connections play a central role in the hermeneutic circle by connecting the parts to the whole as well as in the fusion of horizons. When we encounter a text, we start with 


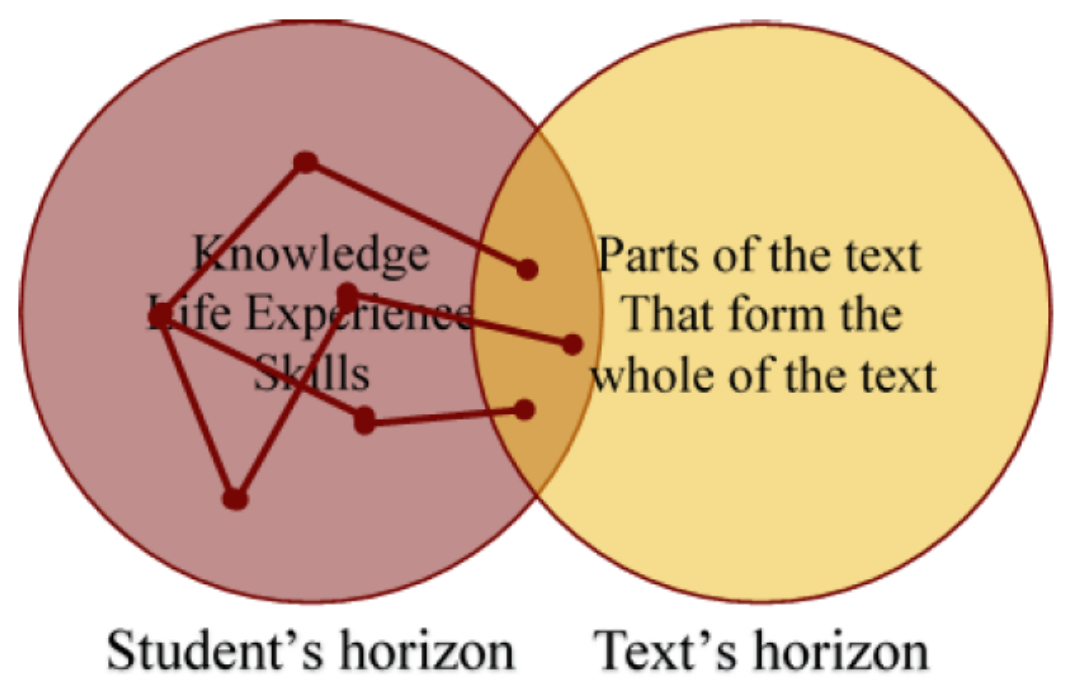

\section{Figure 1.5: Fusion of horizons through connections}

some preconceptions and projections. We use these preconceptions to make sense of the small parts of the text that require a sense of the whole text. There is a series of back-and-forth movements between the parts and the whole. Schleiermacher acknowledged that there is "an apparent circle" in interpretation so that understanding each part of a text requires considering the whole text and vise-versa (Packer, 2010). Heidegger explained that the hermeneutical circle works between understanding and interpretation. Heidegger argued that understanding is the prereflective knowledge that we have of a text and interpretation is the expression of this understanding (Packer, 2010). Gadamer (2004) believed that "A person who is trying to understand a text is always projecting. He projects a meaning for the text as a whole as soon as some initial meaning emerges in the text." (Gadamer, 2004, p. 269). The overlap of horizons is a form of connection, a bond or a link between the horizon of the reader and that of the text. It yields a starting place for the hermeneutical circle. The overlap represents a common knowledge or life experience between the student and the text. Based on this common knowledge, the student engages a hermeneutic circle that toggles between the parts of the text and the whole of the text. The hermeneutic process is triggered by questions, and understanding comes in the form 
of answers to those questions (Gadamer, 2004). There may be connections (Figure 1.5: Fusion of horizons through connectionsFigure 1.5), within the horizon of the student, between the part that overlaps with the horizon of the text and the rest of the student's horizon. Within the process of finding questions and answering them, other connections will form, or, pre-existing ones will become apparent to the student.

This process is that of the hermeneutic circle which oscillates between the parts of the text and the whole of the text. It is during this oscillation that more connections are created or become apparent. Discrepancies may remain and the cycle starts again and again. As a result, more of the text is connected to the student's horizon, which can be viewed as more overlap between the two horizons or as a broadening of the student's horizon toward that of the text.

$\mathrm{RW}$ integrates both questioning and connections as central processes in its application.

\subsection{Hermeneutics and science education}

In 1992, Eger proposed Gadamer's version of hermeneutics as an appropriate framework in science education. Eger argues that a hermeneutic approach to science can help students gain a deeper understanding of 'meaning' in science beyond its role in uncovering causal relationships (Eger, 1992, p. 337). Philosophical hermeneutics has been applied to science to help shed light on the practice and learning of science in an interpretive frame (Bevilacqua \& Giannetto, 1995; Eger, 1992, 1993a, 1993b; Ginev, 1995). In his book Hermeneutics and Education (1992), Gallagher developed a comprehensive account of the application of hermeneutic principles to education (Gallagher, 1992). Borda (2007) used philosophical hermeneutics as it relates to the dispositions (attitudes) of students toward science and studying 
Reflective writing for a better understanding of scientific concepts in high school

science. “Gadamer's philosophy as it relates to his depictions of dispositions necessary for hermeneutic understanding, particularly for those practicing or studying science (Borda, 2007, p. 1030).

Martin Eger (1992) proposed philosophical hermeneutics particularly for science education and avoids discussing its application to science research (without excluding it). He eloquently argues (Eger, 1992, p. 340):

What if we focus our attention not on science as research but on science as knowledge, as it faces us all when we first encounter it? Suppose we consider not the relation of humans to nature but their relation to a particular science. In that case, surely, what they encounter is a language already in being - the language of that science. And this language, before it is mastered, is for everyone as remote as any the anthropologists have studied, since it too partitions 'reality' in a way different from the language with which we start, the natural language of the 'life-world'. This shift of focus, from the study of nature to the study of science, is of course a shift to the educational situation. By turning immediately in this direction, we avoid for the time being the difficult philosophical question of whether the position of the researcher in natural science is itself hermeneutical or, as is often said, 'monological'. Whatever the answer to that may be, regarding the position of the student (scientists included!), we are on much more solid ground: Whenever a strange language is encountered, does it not need interpreting? Whenever there is interpretation, does it not entail hermeneutics? For anyone with the experience 
Reflective writing for a better understanding of scientific concepts in high school

of learning and teaching science, these questions ring true because, in such situations, what the human being faces are not really the phenomena of nature themselves, but various forms of written and spoken text, from lectures to research reports, to textbooks proper - literally, texts.

For students, a scientific text might seem alien, as if it comes from a foreign culture (Kalman, 2011). Eger (1992) mentions that students fail to see meaning in crucial scientific ideas, though they may be competent enough in first-order knowledge and technical manipulation. One should not take for granted that a student would understand a scientific text simply by reading it. For a student reading a scientific text, understanding begins when there is an overlap between the horizon of the student and that of the text (Gadamer, 2004). In the process of doing RW, students are asked to read scientific texts and interpret them.

\subsection{Reflective Writing}

Reflective Writing is a tool developed by Kalman and Kalman (1996) then by Kalman (2008) to get students to metacognitively examine the material in their textbooks before it is discussed in class (Kalman, Aulls, Rohar, \& Godley, 2008). Metacognition is a process during which a person monitors and guides his or her own thinking while they work on a task (Flavell, 1976). Writing allows for metacognition and its sustained use has been shown to encourage development of this cognitive skill in students (Gunel, Hand, \& McDermott, 2009). BangertDrowns et al. (2004) conducted a meta-analysis of 48 school-based writing-to-learn programs. This analysis shows that writing can have a small, positive impact on conventional measures of academic achievement. In particular two factors predicted enhanced effects: the use of metacognitive prompts and increased treatment length. 
RW is a part of the "Writing-to-Learn" movement (Connolly, 1989). RW is a process during which a student writes, in an informal manner, on paper, his or her ideas about a specific topic (the topic is Physics in this study). A rubric (discussed below) provides guidelines for the student during the writing process. In their writings, the students can: argue with themselves, question and criticize themselves or the topic.

Research showed that 'Writing-to-Learn' improves students' conceptual thinking and its strategies can also help students pinpoint their difficulties in solving quantitative problems (Countryman, 1992; Kalman, 2001; Mayer \& Hillman, 1996). Larkin and Bundy (2005) argued that writing can serve as a tool to improve the quality of teaching as well as to promote deeper and more meaningful student learning. McDermott (2010) showed that the "Writing-to-Learn" activity was used by students to generate and clarify their understanding of scientific concepts for themselves. Writing has been offered as one critical tool for promoting this type of scientific literacy in school classrooms (Yore \& Treagust, 2006). Research indicates reading and writing can be thought of as interactive and constructive activities (Keys, 1999; Ruddell \& Unrau, 1994; Yore \& Treagust, 2006) in terms of the ability of the author to both construct their own knowledge as they write and the reader to develop knowledge as they make sense of the writing. "Writing in the science classroom is beginning to be viewed not just as a communication tool, but also as a tool to develop conceptual understanding, that is, an epistemological tool.” (McDermott \& Hand, 2010, p. 519).

Rivard (1994) showed that the use of writing enhances the learning of science content and that is intimately connected to thinking. Numerous studies have shown that engaging students in writing can have a positive impact on their overall course performance (Cisero, 2006; 
Drabick, Weisberg, Paul, \& Bubier, 2007; Soysa, Dunn, Dottolo, Burns-Glover, \& Gurung, 2013).

RW is based on the notion of "free-writing" popularized by Elbow (1973). Countryman (1992) defined freewriting as writing rapidly for a short and fixed period of time. Freewriting falls within the notion of "expressive writing" (Britton et al. (1975)). Britton et al. used the term "expressive writing" to refer to writing to oneself, as one would in diaries, journals and first-draft papers. Expressive writing often looks like speech written down; usually it is characterized by first-person pronouns, informal style, and colloquial diction. Fulwiler (1987) notes that "Some writing activities promote independent thought more than others do. Expressive or selfsponsored writing, for example, seems to advance thought further than rote copying" (Fulwiler, 1987, p. 21). Often when students encounter difficulty understanding particular concepts, the biggest hurdle is recognizing the question rather than recognizing the answer. Thus, asking students to explain difficult concepts to themselves via reflection can help them identify the source of their confusion, which contributes to the development of metacognitive and critical thinking skills (Kalman, 2008; McLeod, 1987). Even though RW is based on the notion of "freewriting", RW is not "free-writing". What sets RW apart from "free-writing" is a rubric (Khanam \& Kalman, 2016) given in 
Table 1.1 (below). The rubric is provided to the students and it asks them to include in their writing certain aspects that enhance understanding. These aspects are questioning and connections. It was shown in this chapter (sections 1.1 1.2 ) that questioning and connections are key aspects of the hermeneutic circle and of understanding through the fusion of horizons (Gadamer, 2004). RW asks the students to have the attitude of a "free-writer"; only the content of the writing must respect the rubric guidelines. Students are asked to read specific material from their textbooks before coming to class and complete a RW task, guided by the rubric and based on what they have read. Their RW products are then read by the teacher and evaluated according to the rubric.

The rubric is designed to engage the students in a questioning process as well as to target connections between the parts/concepts of the course material they read. Each of the four RW aspects targeted by the rubric is evaluated on a four-point scale. The first aspect (line 1 on the table) verifies that the student has read the material and that it was expressed in the RW with his or her own words. The second and third aspects of the table (lines 2 and 3 ) verify that the student looked for connections between the concepts in the targeted course material as well as connections with their everyday lives. The fourth aspect (line 4) triggers questioning. The questioning can be about parts of the material as well as on how concepts are connected. The following chapter (Methodology) includes more details on the use of the rubric.

It is essential to emphasize that RW is not a summary of the material. A summary is a mechanical repetition, on a paper, of the main ideas (whether understood or not) in a given text. A summary does not require reflection, questioning, nor connections between what was read. On the other hand, RW asks the students to express the main ideas in their own words while 
Reflective writing for a better understanding of scientific concepts in high school

interacting with the material through questioning and connection. RW "emphasizes reflective thinking about what students have read" (Huang \& Kalman, 2012, p. 93). 


\section{Table 1.1: Reflective Writing Rubric}

\begin{tabular}{|c|c|c|c|c|c|}
\hline & $\begin{array}{l}\text { Features present } \\
\text { in the reflective- } \\
\text { writing product }\end{array}$ & $\begin{array}{l}\text { Meets criteria } \\
\text { fully }\end{array}$ & $\begin{array}{l}\text { Meets most of } \\
\text { the criteria }\end{array}$ & $\begin{array}{l}\text { Minimally } \\
\text { meets the } \\
\text { criterion }\end{array}$ & $\begin{array}{l}\text { Does not } \\
\text { meet } \\
\text { criterion at } \\
\text { all }\end{array}$ \\
\hline 1 & $\begin{array}{l}\text { Presenting the key } \\
\text { concepts of the } \\
\text { subject as } \\
\text { understood by the } \\
\text { student. }\end{array}$ & $\begin{array}{l}\text { Complete } \\
\text { Does } \\
\text { not copy the } \\
\text { lesson. }\end{array}$ & $\begin{array}{l}\text { Covers all } \\
\text { concepts but } \\
\text { not really in } \\
\text { his/her own } \\
\text { words }\end{array}$ & $\begin{array}{l}\text { Partial coverage } \\
\text { of concepts }\end{array}$ & $\begin{array}{l}\text { No concepts } \\
\text { covered }\end{array}$ \\
\hline 2 & $\begin{array}{l}\text { Describing the } \\
\text { relationship } \\
\text { between the } \\
\text { various concepts }\end{array}$ & $\begin{array}{l}\text { Qualitative } \\
\text { interpretation } \\
\text { used to } \\
\text { compose the } \\
\text { relationship in } \\
\text { the words } \\
\text { of the student. }\end{array}$ & $\begin{array}{l}\text { Surface } \\
\text { description of } \\
\text { Qualitative } \\
\text { interpretation } \\
\text { used to } \\
\text { compose the } \\
\text { relationship }\end{array}$ & $\begin{array}{l}\text { Some attempt } \\
\text { to compose } \\
\text { the relationship. }\end{array}$ & $\begin{array}{l}\text { Not able to } \\
\text { interpret. }\end{array}$ \\
\hline 3 & $\begin{array}{l}\text { Student relates } \\
\text { key concepts to } \\
\text { his/her own life } \\
\text { experiences }\end{array}$ & $\begin{array}{l}\text { Shows clear } \\
\text { understanding } \\
\text { of how the } \\
\text { concepts occur } \\
\text { in everyday } \\
\text { situations }\end{array}$ & $\begin{array}{l}\text { Shows partial } \\
\text { understanding } \\
\text { of how the } \\
\text { concepts occur } \\
\text { in everyday } \\
\text { situations }\end{array}$ & $\begin{array}{l}\text { Mention of } \\
\text { everyday } \\
\text { situations } \\
\text { without any } \\
\text { explanation of } \\
\text { how they relate } \\
\text { to concepts } \\
\text { under study in } \\
\text { current sections }\end{array}$ & $\begin{array}{l}\text { No } \\
\text { relationships } \\
\text { to his/her } \\
\text { own life } \\
\text { experiences } \\
\text { are given. }\end{array}$ \\
\hline 4 & $\begin{array}{l}\text { Student } \\
\text { formulates his/her } \\
\text { own question(s). }\end{array}$ & $\begin{array}{l}\text { Student } \\
\text { realizes that } \\
\text { there are } \\
\text { concepts in the } \\
\text { textbook that } \\
\mathrm{s} / \text { he does not } \\
\text { understand } \\
\text { and elaborates } \\
\text { a clear } \\
\text { question }\end{array}$ & $\begin{array}{l}\text { Student sets } \\
\text { out a question } \\
\text { that is not } \\
\text { clearly } \\
\text { formulated }\end{array}$ & $\begin{array}{l}\text { Student notes } \\
\text { the difference } \\
\text { between his/her } \\
\text { own ideas and } \\
\text { the ones in the } \\
\text { textbooks } \\
\text { without any } \\
\text { discussion }\end{array}$ & $\begin{array}{l}\text { No questions } \\
\text { given }\end{array}$ \\
\hline
\end{tabular}


The RW tasks, guided by the rubric, are intended to enhance two key aspects of understanding which are connections and questioning. Nersessian $(2008$, p. 3$)$ elaborated on the importance of relating concepts in the process of understanding:

Concepts provide a means through which humans make sense of the world. In categorizing experiences we sort phenomena, noting relationships, differences, and interconnections among them. A conceptual structure is a way of systematizing, of putting concepts in relation to one another in at least a semi or locally - coherent manner... Trying to understand new experiences or how a concept relates to others can reveal heretofore unnoticed limitations and problems in the representational capabilities of current conceptual structures and even reveal inconsistencies with other parts.

The habits of questioning and connecting concepts to other concepts and to our daily lives are identified as habits of expert learners. The existing knowledge of capable students and experts is highly interconnected and new knowledge is immediately linked in many ways to prior knowledge (Larkin, McDermott, Simon, \& Simon, 1980). Research has shown that differences in problem representation by novices and experts reflect differences in knowledge structure (Austin \& Shore, 2011; Chi, Feltovich, \& Glaser, 1981). Strong connections distinguished expert learners from average and weak and enhancing their connection skills improved their course performance (Austin \& Shore, 1994; Shore, 2009).

Questioning, particularly, is identified as a corner stone of inquiry in science. Inquiry generally refers to a process of asking questions, generating and pursuing strategies to investigate 
those questions by generating data, analyzing and interpreting those data, drawing conclusions from them, communicating those conclusions, applying conclusions back to the original question, and perhaps following up on new questions that arise (e.g., Krajcik et al., 1998;

National Research Council, 1996; Sandoval, 2005; Shore, 2009; White \& Frederiksen, 1998). “In dialogue that takes place within inquiry learning, and through the process of asking questions about what they learn, students demonstrate improved memory of core information" (Shore, 2009, p. 165).

\subsection{Reflective writing and classroom discussions (role of the teacher)}

This study evaluates the impact of RW in a high school physics course, where the RW exercises were followed by classroom discussions. It was shown that an activity that gets students to examine textual material metacognitively (i.e., RW) with one or more interactive interventions can produce epistemological change; students' epistemological beliefs became more expert-like (Kalman, Sobhanzadeh, Thompson, Ibrahim, \& Wang, 2015).

The goal of the teacher-lead classroom discussions that followed the RW assignments was to:

- Allow students to express their ideas, questionings and relations with respect to the course material they read.

- Allow the teacher to help students overcome difficulties or misconceptions encountered during the RW tasks.

- Initiate debates that engage students in stimulating discussions that can expose different aspects and perspectives of the same situations. 
The positive impact of discussions and of teacher intervention is well supported by research. Knowledge is constructed in the social context of the classroom through language and other semiotic means. Central to Vygotsky's (1978) sociocultural theory of learning is the idea that conceptual knowledge first appears between people on an interpsychological plane, and then inside the learner on an intrapsychological plane. The notion of the teacher assisting student performance through the "zone of proximal development" also suggests that teachers can guide the discourse on the interpsychological plane to support student learning (Chin, 2006). This recognizes the importance of teacher-student discourse in the classroom, which may be considered as a form of scaffolding (Bruner, 1986; Wood, Bruner, \& Ross, 1976).

Aulls (2002) observed a number of teachers as they implemented constructivist activities in their classrooms. He described the "scaffolding" that the most effective teachers introduced when students failed to make learning progress in a discovery setting. He reported that the teacher whose students achieved all of their learning goals spent a great deal of time in instructional interactions with students by simultaneously

teaching content and scaffolding-relevant procedures ... by (a) modeling procedures for identifying and self-checking important information...(b) showing students how to reduce that information to paraphrases ... (c) having students use notes to construct collaborations and routines, and (d) promoting collaborative dialogue within problems. (p. 533)

Scott (1998) suggested that learning will be enhanced through a balance between presenting information and allowing exploration of ideas. van Zee and Minstrell (1997) 
examined ways of speaking that were characteristic of "reflective discourse". In such interactions, students articulated their own ideas and posed questions; and teachers and students engaged in an extended series of questioning exchanges. Teachers helped students develop understandings through a process of negotiation rather than transmission or confrontation of misconceptions. Teaching strategies included soliciting students' conceptions, using reflective questioning, and invoking silence to foster student thinking. Baird and Northfield (1995) argued that in such lessons, the teacher's intent is to elicit what students think, to encourage them to elaborate on their previous answers and ideas, and to help students construct conceptual knowledge and to scaffold students' thinking.

In another study on teacher questioning during conversations about science, van Zee, Iwasyk, Kurose, Simpson, and Wild (2001) found that teachers could elicit student thinking by asking questions that developed conceptual understanding, and practising quietness through long wait times, attentive silence, and reticence. The teachers' questions included those that elicited students' experiences, diagnosed, and refined student ideas, as well those that helped students to clarify, explore, and monitor their various points of view and thinking.

Shore and Kanevsky (1993) emphasized the importance of teachers responding to student's needs and recommended practices for teachers. These included helping students to make broad connections in memory, using knowledge widely in new situations, relating new learning to old and reinforcing and modeling metacognitive strategies. These recommendations can be applied in all RW tasks as well as in the classroom discussions that followed. 


\subsection{Reflective writing in high school science courses}

Reflective Writing has been widely applied with postsecondary students in many disciplines (Dukewich \& Vossen, 2015; Kalman et al., 2015; Kalman, 2011). Most (if not all) of the research done on reflective writing that involves science courses, has been done with postsecondary students. This study aims to shed light on how Reflective Writing affects high school students' understanding of science. Of the many aspects that set secondary students apart from post-secondary students, I would like to mention a few as follows:

- Cognition. Because of the age difference (and numerous factors beyond the scope of this discussion) secondary and postsecondary students do not approach learning in similar manners (Piaget, 1978).

- Environment. The school environment is not the same as that occurring in CEGEPs (Junior College) and in universities. The interactions between the students, and between the students on one side and the courses, teachers, and administration on the other side, are not the same in secondary and postsecondary institutions.

- Choice. One type of choice is that of the institution. Secondary students are minors, they do not usually choose the school, whereas CEGEP and university students have more (if not all) to say about the choice of the institution. The other type of choice is that of majors and courses.

- Course diversity, structure, and workload. Secondary and postsecondary institutions do not offer the same courses and courses are not structured in similar ways and with similar workloads. 
Reflective writing for a better understanding of scientific concepts in high school

The purpose of this distinction between secondary and postsecondary students is to justify the study made with secondary students on the basis that there are enough differences between the two. 


\section{Chapter 2: $\quad$ Methodology}

This chapter includes the methodology used in this study, as well as a description of the participants and their selection procedure. It highlights processes employed to collect two types of data from participants: answers to interview questions and RW products. A brief description of the interview questions is also given.

\subsection{Multiple case study; an overview}

Today, case studies account for a large proportion of the qualitative research presented in books and articles in psychology, history, education, and medicine (Starman, 2013). "Much of what we know today about the empirical world has been produced by case study research, and many of the most treasured classics in each discipline are case studies" (Flyvbjerg, 2006, p. 302).

Mesec (1998) gave a broad definition of case study:

It is a description and analysis of an individual matter or case $[\ldots]$ with the purpose to identify variables, structures, forms and orders of interaction between the participants in the situation (theoretical purpose), or, in order to assess the performance of work or progress in development (practical purpose. (p. 383).

Case-study research builds an in-depth, contextual understanding of the case, relying on multiple data sources (Yin, 2014). Case-study research is presented as an inquiry strategy, a methodology, or a comprehensive research strategy (Denzin \& Lincoln, 2005; Merriam, 1998; 
Yin, 2014). As Yin (2014) stated, "You would want to do case study research because you want to understand a real-world case and assume that such an understanding is likely to involve important contextual conditions pertinent to your case" (p. 16).

In a collective or multiple-case study, the researcher again selects one issue or concern but also selects multiple case studies to illustrate the issue and to show different perspectives on the issue (Creswell, Hanson, Clark Plano, \& Morales, 2007). Yin (2014) suggested that the multiple-case design uses the logic of replication in which the procedures are replicated for each case. The analytic strategy would be to identify issues within each case and then look for common themes that transcend the cases. Lincoln and Guba (1985) proposed to end the case study with a broad interpretation of what was learned from studying the cases.

The number of participants in case studies is usually limited because, to develop an indepth understanding of each participant about the issue under study, the more participants are selected, the less details can be developed for each of them (Creswell et al., 2007). However, to best generalize, the inquirer needs to select representative cases, based on the research problem, to include in the qualitative study (Yin, 2014).

\subsection{An overview of the study}

The goal of this study was to evaluate the impact of RW, followed by classroom discussions, on high school students. It aims to show the perspective of different participants following their experience with RW. There are two types of data collected for every participant: (a) their answers to questions in semistructured interviews (Merriam, 1998) and (b) six RW products. The depth of the data collection limited the number of participants to six. However, to best generalize the results, based on Yin (2014), representative cases of students were selected as 
participants. Participants in this study were 6 high school students in secondary 5 (Grade 11), taking a physics course as a part of the required courses in the Quebec educational system. Two of the participants are A-students (high achievers), two others are B-students (medium achievers) and the last two participants are C-students (weak or failing achievers). Participants are all girls, attending the same private school in Montreal, the same school where I teach and I am the physics teacher of all participants. Three of the six participants are in one group and the other three are in another group. All participants are science students who have chosen the natural science option (SN) in secondary five. The combined number of students in both groups is 59 . All the students completed the RW tasks as a part of their required course work but only 6 of them participated in the study and were interviewed at the end of the course. The selection process of the 6 participants is described below.

\subsection{RW as a part of the physics course}

RW was introduced to the student as a part of the normal tasks required in the physics course. This course includes two main sections: Optics and Mechanics. The RW tasks given to the students covered Mechanics, both Kinematics and Dynamics. This is the first Mechanics course the students take in school. In its kinematics part it covers mainly Uniform Rectilinear Motion, Uniformly Accelerated Rectilinear Motion and Projectile Motion. In its dynamics part it covers mainly Newton's Laws of Motion. A brief description of RW was given in class. The first reaction of the students was surprise. Most of the students found it strange that in a science course the teacher is asking them to write as they do in a journal or a diary. They found it unconventional to be asked to write about their ideas on science and how concepts relate to one another and not to solve science problems that produce numerical answers, especially the fact that RW did not include any calculations. This particular point was verified by many students 
repeatedly in both classes. The students asked questions to verify what was actually required from them in completing the RW tasks. To guide the students in their writings, they were provided with a brief guide describing the main steps for completing a RW which also included the evaluation rubric (Appendix D). The rubric highlighted the parts that RW should include. During the introduction of RW to the students, two points were emphasized:

1) RW is not a summary and must not be treated as such. A summary is a list of the main ideas in a given part of the material, whereas RW is a description of what these ideas represent to the writer, how they connect to one another and to the daily life of the writer.

2) Their RW will be evaluated according to the presence of connections and not on the validity of those connection. Students were reassured that they will not be penalized in case they made wrong connection, however they could be penalized for lack of connections.

\subsection{The interviewers}

All my secondary five students were doing the RW exercises as a part the Mechanics course. However, not all students were going to be interviewed, so a process was put in place to select the students that will take part in the study. The main challenge was to conduct the study with my students without affecting the regular course work and interactions. To get as close as possible to this goal two decisions were taken:

(1) I must not be the person conducting the interviews. This decision was made to eliminate any intimidation that participants might feel when interviewed about their experience with the RW activity. One has to admit that a student might be intimidated, when asked 
by her teacher, no matter how tolerant that teacher is, to give her opinion about a study that this teacher is conducting.

(2) I must not know who the participants are. In fact, all that I knew was that 6 of my 59 students were going to be interviewed about their experience with the RW exercise. This decision was made to eliminate any awkwardness that the students or myself might feel during class discussions, or during regular class activities and evaluations.

Based on these decisions, the obvious question became: Who will select participants to the study from the students and conduct the interviews? Following the proposition of Professor Kalman, I asked two of my colleagues (teachers at the school) to select the participants and conduct the interviews without me knowing their identities until the end of the course, after all the interviews have been conducted and the course grades submitted. I was left to play the teacher's role until the end of the course, then I took again the researcher's role to analyse the data and make conclusions. This chapter describes the process of data collection, from the selection of the teachers conducting the interviews, to their selection of the participants followed by the interviews.

\subsection{Participants}

Participants in this study were high school students from a Montreal school. They were asked to complete Reflective Writing tasks as a part of their science course work. Their writings were analyzed and compared to their attitudes and opinions toward the subject. These attitudes were probed by interviews following the reflective writing exercises.

To select participants and to conduct the interviews, I asked the help of two of my colleagues (teachers at the same school). Both are secondary 5 teachers, well known and 
respected by the students. The first one (T1) is the history teacher (male) and the second one (T2) is the math teacher (female). Over the course of three meetings (two before the selection process and one before the interviews), I introduced the study to them, explained the general process and what role they will play. Each teacher was assigned to one group of students (there are only two groups of science students at the school). They were given specific instructions on how to manage the selection process, the consent forms and scheduling and conducting the interviews. All without informing me about the identities of the selected students. The instructions they were given before selecting the participants included:

- Introduce the study to the students as a part of Joseph El-Helou requirements to obtain a Master's degree in Physics from Concordia University (in fact, RW was introduced to the students by me as a part of their course's regular work and not as the topic of my thesis).

- Ask the students for volunteers to take part in the study. Volunteers will be interviewed toward the end of the course (the school year) and will be asked about their opinions regarding their experience with RW and the physics course.

- Inform the students that Joseph El-Helou will not be selecting the students, nor will he be conducting the interviews. He will not know the identities of the students participating in the study until the end of the course, after all the interviews have been conducted. The reason behind the secrecy is that he is the principle investigator. The fact of him being involved in the selection process as well as in the interviews, can be regarded as a conflict of interest and a basis to disqualify the study.

- Inform the students not to discuss any of the aspects mentioned with their teacher (who the volunteers are, the selection and the interviews). Ask them to continue to interact 
with the course, with RW and with their teacher as they did before knowing about the study.

- Inform the students that their identities will not disclosed throughout the study. Joseph El-Helou will know who the participants were only after all the interviews have been done.

- Inform the students that their participation in the study or their lack of, will not affect their course grade nor their relation with their teacher.

After announcing the study in their respective classes, 6 students volunteered in the class of $\mathrm{T} 1$ and 16 students volunteered in the class of T2. T1 and T2 were each asked to select 3 students in their respective classes with different academic levels (one high performer in Physics, one medium and one weak). The teachers made their selection based on the class lists populated with students' physics grades. The teachers informed the students that they were selected for the study and they were given the consent form (Appendix B) along with an introduction letter (Appendix A) that presents the goals of the study. The consent form requires the signature of the participating students along with that of their parent/guardian. The teachers received back the dually signed consent forms from all participants and kept them in their possession, till after all the interviews have been completed, at the end of the course. This measure was necessary to keep the identities of the participants from me.

Without disclosing identifying details, the teachers $\mathrm{T} 1$ and $\mathrm{T} 2 \mathrm{kept}$ me informed of the progress (the number of volunteers in every class, when they received the signed consent forms). During that time I was giving the course without discussing the study with my students. Students also kept their side of the bargain by never bringing up the study into class conversations. 


\subsection{Conducting the interviews}

After six RW exercises it was time for the interviews. The teachers were given the OK to schedule the interviews with their respective participants. As noted in the introduction letter

(Appendix B), interviews were to take place, at school, during lunch breaks (the lunch break lasts 50 minutes). Prior to the interviews, the teachers were given the Interview Guide (Appendix C) along with a set of instructions. A third meeting was also set up with them to clarify the process and unify the approach. As a part of the instructions given, the teachers were asked to:

- Reassure the participants that their identities will not be disclosed.

- To audiorecord the interviews on two separate devices (one for backup).

- To record comments about participants' attitudes or reactions which are not caught by the audiorecording device.

The meeting also included an overview of the interview questions in the guide. In particular, it was noted to the teachers that the questions 3 to 6 of the interview guide were intended to inform us of the participants' study habits prior to the RW exercises. These questions must not take up more that $25 \%$ to $30 \%$ of the interview time. The rest of the interview must be dedicated to the rest of the questions. These questions ( 8 to 21 of the guide) focus on participants' reactions and attitudes toward the RW exercises and the physics course.

\subsection{The interviews and the interview questions}

The interviews were conducted as scheduled by the teachers. Both teachers scheduled all 6 interviews during the last two weeks of June 2016. They reported that all 6 students were comfortable throughout their respective interviews. None of the teachers reported any significant 
reaction of the students that was not caught by the audiorecorder. The teachers tried to follow the Interview Guide as much as possible while interacting in a normal manner with the students' answers to the questions. Some specific questions (or probes) were not asked by the teachers because they felt that the answer to those questions was already given in a previous one. So the interview must be taken as a whole and not as fragmented parts, as restricted answers to restricted questions.

At the end of the course, after all 6 interviews were completed, the teachers delivered the audiofiles of the interviews along with the signed consent forms they had kept in their possession. The teachers were specifically asked to delete any and all copies of the audiofiles. At this time, the identity of the participants was revealed to me, when all the course grades had been submitted and only one course session (of 45 minutes) was left in each class. That gave me the time to thank all participants and to obtain general feedback form both classes about their experience with the RW exercises.

All the interviews were transcribed (in French) and students' answers to the respective Interview Guide questions were grouped in the table in Appendix E. When necessary, passages from the interviews are translated to English and included in the body of this thesis along with their reference to the table. The last column of the table assigns a number to every answer in the table for easy access. Students' answers and the results of the study are discussed in the following chapter. 


\section{Chapter 3: $\quad$ Results}

This study aimed to identify the impact of RW on students' understanding of scientific concepts in high school. Interviews were conducted with participants that completed six RW exercises. In this chapter, the results of these interviews and the RW products of the students are discussed. Both of our data sources, the interviews and the RW products of the participants, systematically showed that RW exercises, followed by classroom discussions played a positive role in enhancing students understanding as well as improving the classroom interactions and dynamics.

Full transcripts of the interviews are grouped in the table in Appendix E. The participants answering the interview questions are identified (in the table and throughout this text) with a four character code, for example: "T1SA". Where "T1" stands for Teacher-1, "S" stands for student and "A" represents the academic level of that student. It was mentioned in the previous chapter that each teacher selected three participants, from those who volunteered, with different academic performances in the Physics course (an A-Student, a B-student and a CStudent). Which means that, for example, the student labeled T2SB, is a B-student interviewed by Teacher-2.

Every quote from the interview transcripts in the table, used in this text, is accompanied by a number which indicate its row in the table. The purpose of the number is to allow the reader to easily locate the quoted part in the table (the table is relatively large). All quotes include the student code and its row (identified by the letter "R") in the table and have the following form: “T2SA-R112”. 
The results presented in this chapter are categorized according to the impact of the RW exercises on students in particular, as well as on the teaching process in general. In support of the arguments made, passages from the interviews are selected along with parts from the RW exercises.

\subsection{Impact of RW on the students}

The main question of this study was to evaluate the impact of RW on students' understanding of physics concepts as well as its impact on students with different academic levels. The RW exercise was designed to initiate questioning and connections, two processes that enhance understanding. The RW exercises were followed by classroom discussions, led by the teacher. In this section, the impact of RW followed by the classroom discussions, will be discussed. The interviews conducted with the students showed that RW had a direct influence on their understanding of physics as well as helping them to participate effectively in their physics course. RW helped them better understand the material, better relate it to their everyday lives, better formulate questions as well as helping them to be involved in the course content and course discussions. Results also showed that RW's impact on an A-student is different than that on a C-student.

\subsubsection{RW and understanding}

All the interviewed students clearly and repeatedly stated that the RW exercises allowed them to better understand the subject and to better relate the concepts they read about to one another and to their daily lives. Students' understanding was not directly measured in this study, however, their replies to the interview questions were directly linked to the processes that are 
Reflective writing for a better understanding of scientific concepts in high school

intricately related to understanding (connections and questioning). The quotes from the interviews listed below show the general reaction the participants had to RW.

T1SA-R127: It allowed me to know the things I did not understand, it helped me organize the way in which I see the material.

T1SB-R134: ...I personally find that reflective writing helps in understanding... it really helps to understand because it is good to do the reading before the course, because we already know what it is about, we have an idea.

T1SC-R111: ... I think we already come to class with an idea of the material, which helps a lot especially with Newton's laws, and I do not think that I would have really understood the material if I had not analyzed it in a reflective writing.

T2SA-R112: ...reflective writing for me was most helpful when we did Newton's three laws and I think that... had I not read, I would not have understood them this well, had I not done reflective writing. Because it pushed me to question myself and to give examples of everyday life and that pushed me to try to understand... but maybe had I not done it, I wouldn't have understood. 
T2SB-R113: Yes, I find it helps, reflective writing, to assimilate ideas and also it helps me when the teacher gives the course after my reflective writing, because I, first I already read, and surely you understand better when you've already read before and also when the teacher explains, I make the connection with what I have read, then yes it helped me better understand.

T2SC-R114: Yes, especially for the laws of Newton, we had read at home, we did reflective writing and then we explained in class, it helped me understand much better, as it helped me as a reference.

T2SC-R144: It (RW) allowed me to understand a lot better, and when I used my own thoughts...I was writing my own ideas, that facilitated my understanding, even when we did the chapter before the teacher explained it to us in class, it allowed me to know what he will explain to us, what to expect... and if there were questions that I did not understand, I could ask them directly.

The RW products of the students were not meant to show exclusively that the students understood what they read about. However, in many parts, the RW products clearly showed that they understood many aspects of the subject before coming to class. The passages that follow are samples of numerous times where the participants showed, in their RW, that they were able to understand different concepts ahead of class time. 
RW-T1SB on inertia: ...Regarding inertia, I understood this phenomenon at the time during which the bus slows down and the movement of my body continues because my body was at a constant rate, because there were no external force on my body.

RW-T2SA on free fall: ...I understand that free fall is when an object is moving in the air with only the gravitational force acting on it .It is a movement that can be upward or downward because, if I throw an apple in the air and I leave it to only the gravitational force it's going to cause the apple to fall toward the Earth of course because it's very strong.

RW-T1SC on Newton's second law: ... It is probably the most logical and most comprehensible, it is obvious that the greater the force exerted on a body is, the greater the acceleration is going to be. Having said that, the applied force is proportional to the acceleration. If I push a cart at Costco it's going to accelerate, but if I push it with a friend, it's going to accelerate even more. The notion of mass is also very important in Newton's second law, the greater the mass the smaller the acceleration. This means that the mass and acceleration are inversely proportional. The heavier the cart I'm pushing at Costco, the less its acceleration is going to be.

RW-T2SB on projectile motion: There's a horizontal force and vertical one exerted on the body during the launch of the projectile, the vertical force pushes upward whereas the horizontal force will push it sideways, then the 
gravitational force would pull the body gradually downward. If the force of gravity was not there, the body would keep on traveling in a tilted trajectory without really falling back to the ground.

RW-T2SC on Newton's first law: What I understood from Newton's first law is that when there's no external force, or if it's zero, the body would remain at rest or in a uniform rectilinear motion (zero acceleration) actually it (the force) modifies the movement of the body if it wants to move it, accelerate it, or slow it down, or stop it, a force must be exerted on the body. If there's no external force exerted on it the acceleration would be zero, which means, if a body is at rest, it will remain at rest and of the body is in motion it will keep on going with the same speed on the same line.

\subsubsection{RW and course material}

All the students appreciated the fact that RW allowed them to be prepared for what was going to be covered in class. They all expressed, in different ways, the advantages of knowing what the teacher is about to cover in the next class and how positively it affected their understanding, their attendance in the course and their interaction with the subject. Reading course material before class allowed students to connect their initial knowledge to the material as well as to connect the material to their everyday lives. Some expressed the impact of knowing what the lesson was going to be about on the classroom dynamics and how it amplified the discussions. It also amplified the students' interest in the intricate details of the subject (discussed in 3.3 ). For a teacher, this is extremely valuable. Whether the students understood 
Reflective writing for a better understanding of scientific concepts in high school

what they needed to understand from the RW or not is secondary. The primary thing is to get them interested in understanding and trigger their questioning of the concepts and of the connections that relate them. The normal course work that follows their RW (including classroom discussions, lab work, team work, projects...) will assist them in finding the suitable concepts. Gadamer (2004) recognized this process: "Interpretation begins with fore-conceptions that are replaced by more suitable ones" (p. 269). Hewson and Hewson (1984) suggested that if a student holds a personal scientific concept, he or she does so because the student finds it to be plausible. Thus instruction must not only be aimed at showing that the replacement concept is intelligible, but must also first seek to reduce the plausibility of the personal scientific concept. Kalman et al. (1999) argued that it is far better to get the student to critically analyze the two concepts and come to the realization that the personal scientific concept needs to be replaced.

T1SC-R141: ...It (RW) allows me to do a complete analysis about the material and already have an idea about the subject, even when one has not yet seen it in class.

T1SB-R146: I think it helps to understand, it helps to think about the question. It's just... before a course, we can all interact together, the material is not too abstract for the girls in the class, because they all have already read about it, so it just helps to advance the course more quickly.

Even when they did understand something in physics, participants reported that RW helped them deepen their understanding of concepts that they were already comfortable with. 
Reflective writing for a better understanding of scientific concepts in high school

T2SA-R175: ...I have the impression that I do not understand everything, before I was like, yes I understand, but actually I did not understand, It (RW) allowed me to understand better, deepen what I know and what I do not know, to understand, to go further.

T1SB-R164: ... (RW) helps to put my ideas in place. If ever I was not doing reflective writing, maybe I'll ask myself a question and move on, but reflective writing forces me to think about it and try to answer my own questions.

Students also reported that RW improved their preparations for formal evaluations such as tests and quizzes.

T2SA-R214: ...but even after, for my exams, I didn't need as much time to study, because I knew I understood the material, I don't know if that makes sense, for example, instead of reading the textbook before the test and then ask my questions to Mr. Helou, I had already done this up front, I had all this time to analyze and retrieve any questions, when exams came, I understood already, so I just had to quickly revise and then I did not need the same time before exams

Students particularly highlighted how simply writing their thoughts helped them understand better and answer their questions 
T1SB-R176: ... I read the textbook anyway before the evaluations, but did it (RW) change the way I learn? Yes, because it forces me to make connections, and then with the connections we understand better.

T2SB-R137: ... it was a good way to learn about the subject, assimilate and make connections, assimilate knowledge, it also allows you to write, writing for me is especially a good way to understand, to retain notions.

T2SC-R210: ...With reflective writing, it really allowed me to write my thoughts and if, for example, if I asked myself questions, if I was able to answer, and if I was not able to answer in a rather satisfactory way, I could later talk about these questions with Mr. Helou and he could answer me.

T1SB-R212: Yes, I would recommend it (RW), even if it is not required by the teacher, because it helps to understand, not necessarily to write, but it's true that it is always better to write, because I believe when learning, when you hear it, you learn better, when you read it, you learn better and when you write it, you learn even better. So if you can combine all of this it just makes understanding better. So I would recommend it, or at least just read the chapter before.

One student (T1SB-R158) mentioned that, when you write, even if it is supposed to be for a diary, knowing that somebody is going to read it, you have to make it clear for them, and by doing so you make it clear for yourself and that makes you understand it better. 
Of all the interviewed participants, only one student, T2SB (quoted below) had the habit of reading course material before class time. That particular participant mentioned that she used to read course material before coming to class and that this part of RW (the reading part) was not new for her. However she specified that with RW, she was forced to write about what she had read and to make connections, which helped her significantly in understanding. Before RW, she used to read and generate questions, but with the RW exercises and the connections she made while writing, she understands better and even answers her own questions. Something she is not used to with simply reading course material.

T2SB-R131: ... when I read, I ask myself questions, reflective writing helped me put them in my words and write them and also answer them, because sometimes, often when I have questions when I read, I do not find specific answers, accurate, immediate, but with reflective writing, when thinking (about connections) I read again and answer. So I would say it helped me to formulate questions and answer them too.

T2SB-R179: I think reflective writing, as I already mentioned, I get to know the course material before (class), but it (RW) allowed me to put them on paper, to write and also to identify important ideas.

\subsubsection{RW and academic level}

An interesting aspect to RW is that it does not affect all the students in the same way. In particular, students with different academic levels are affected by RW in ways that correspond to 
Reflective writing for a better understanding of scientific concepts in high school

their state of knowledge and level of understanding. Below are different perspectives to the advantages of RW. The following two perspectives are those of C-students. Before RW, these Cstudents considered the physics course as abstract and they felt that they were not involved in the course and in the classroom discussions.

T1SC-R165: ... usually I do not ask a lot of questions in class, in physics, or I do not answer a lot, because, first, I don't know, physics is a course where I don't answer a lot, I don't know really, an idea, especially in physics, is so abstract, you have no idea what you understand and what you don't understand. Sometimes I 'm just there, sitting and I wonder if it's just me or is it the class that doesn't understand, that was my initial attitude, I was afraid of sounding stupid because I didn't think I had done enough research about the subject, so I never asked questions in class because I was afraid to look stupid, and when I made my reflective writing, it looks like I did a search and I was less afraid to look stupid so I asked him (the teacher) as many questions as possible.

T2SC-R216: Personally, I loved reflective writing, it helped me, you might say, enriched me in a sense, it also helped me in my understanding because, usually when Mr. Helou explains a new chapter, one we did not do, we had not seen previously in the textbook, at first, I would be a bit lost with the examples he gives and everything, but with reflective writing it helped me make connections before he explains the material and therefore to target my weak points. 
Reflective writing for a better understanding of scientific concepts in high school

It is clear, from what these C-students are saying, that RW helped them get actively involved in the subject and in the classroom interactions. They have more self-confidence when it comes to discussing the concepts and making connections. The next perspective is that of an A-student who found in RW a means to understand and to push further her understanding.

T2SA-R166: ... I was writing and I was questioning myself about issues, and then I thought, ok, I understand that, I understand that, but then I get to a new stage, this one I don't understand, why? I don't know, I just don't understand it, I don't see the connection, I am not able to make the connection on my own, so there I say to myself, that I will ask Mr. Helou about the next day, and for example if I understood well something, then I would say to myself that I would ask Mr. Helou how he can make it more difficult?... To push (understanding) further.

These comments from C-students and from A-students show that RW helped the weak student become stronger and the strong student become even stronger. In another part of her interview (quoted below), that first C-student, acknowledged that RW allowed her to discover the "deeper" nature of physics, the one that has to do with concepts and relations. A nature that goes beyond "solving exercises". She even concluded her interview by saying she "adores RW" (T1SC-R213).

T1SC-R177: ...(RW changed the way I understand) because usually when I try to understand I do more exercises, I read, then I do other exercises, but here it was more going deeper, and I think that that's what physics is. 
Reflective writing for a better understanding of scientific concepts in high school

T1SC-R207: To be honest I would not have written things about physics, it is not something on which I write... this year I really discovered that physics was not what I expected, it was much, I don’t know, it made me more passionate . (T1: did you discover this because of reflective writing?). Yes, Yes.

\subsubsection{RW and Connections}

RW helped participants make connections between different concepts of the subject as well as how those concepts relate to their everyday lives. The importance of connections and relations is essential for any meaningful understanding of any material (as discussed in chapter 1, based on Gadamer, 2004). Even when participants were asked how they identify that they've understood something, three of six participants (quotes below) related it directly to the connections they can make. The other three participants indirectly related it to connections and relations. Participants who did not use the term "connections" mentioned how the material "corresponds" to what they already know or if they could "use" it or if they could "explain it" to others.

T1SA-R91: If I am able to explain it to someone else or to say out loud.

T1SB-R92: If I can make connections with other aspects that I read, let's say, in a chapter we are not talking about only one thing, we talk about many things, if I can make a connection between everything that I read and I can visualize it, like make a drawing that explains it, I know I understood. 
T1SC-R93: Usually if I read something and after that the teacher will explain it in class, and if it corresponds to what I thought, that's how I know that I understood.

T2SA-R94: If I solve a problem after, if someone asks questions later, and I answer correctly, also if I feel that I understand what the teacher says after.

T2SB-R95: ... when I read... if I do not understand the sentence, I'd read again I'd try to understand, sometimes, if there is an image, I'd see it corresponds to other explanations, I'd also try to make connections to understand what I do not understand.

T2SC-R96: When I redo the exercises or repeat revision exercises, because I'd get them right without necessarily using my notes, that is how I know that I've understood.

In other parts of their interviews, participants clearly acknowledged the importance of the connections they made and the role RW played in their facilitation.

T2SB-R113: I find that reflective writing helps to assimilate ideas and also its helps me when the teacher gives the course after my reflective writing, because I, first I already read, and surely you understand better when you've already read and also when the teacher explains, I make the connection with what I have read, then yes it helped me better understand. 
T2SB-R137: ...it was a good way to learn about the subject, assimilate and make connections, assimilate knowledge, it also allows you to write, writing for me is especially a good way to understand, to retain notions.

T2SA-R160: ... I started writing I thought, is it like that? after that I thought to myself, it's really not like that, and I wrote that in my reflective writing because I was making connections as I wrote. Maybe, because I had to write about this subject, and to question myself while making connections with other subjects on the outside.

T2SC-R216: ... at first, I would be a bit lost with the examples he (the teacher) gives and everything, but with reflective writing it helped me make connections before he explains material and therefore to target my weak points.

The content of the RW of participants frequently manifested the connections they made with the different concepts. The passages below are samples of connections their RW contained. These passages contain evidence that students connected concepts of the material.

RW-T1SC; on Newton's third law and the force: This action reaction law is totally logical, because at the beginning of Dynamics we saw that the force is an interaction between two objects this means that both objects are going to exert forces on one another because it's an interaction. This means that the two bodies are exerting forces one on the other. One must not neglect that the action force and the reaction force are opposite, but I think this is obvious, 
because for example, if my hand exerts a force on a table, the table will also exert a force on my hand because my hand is mutually interacting with a table [the student drew a diagram of the hand and the table showing opposite forces].

RW-T1SA; on the connection between Newton's second law and Inertia: If we are pulling a truck and a small car, their accelerations would be different because they don't have the same mass. That means they're not proportional, the truck is way heavier and more difficult to pull, which means its acceleration will drop. This is actually inertia, if the object is more massive it has more tendency to maintain its state of motion. The smaller car, it's much easier to pull because it has a lower mass so its acceleration is going to be greater than that of the truck.

RW-T2SB; on Newton's third law and a previous classroom example... So we can say that for every force vector exerted on a body, an opposite force vector will be simultaneously exerted on that body. One must have two bodies to have a force. For example, one body with a surface or one body at a distance with a magnet. If we take the example of the electron alone in the universe a force could not be applied because there's no other body than the electron.

\subsubsection{RW and questioning}

Questioning along with connections play the major role in the process of understanding (Gadamer, 2004). The RW exercises helped students generate questions about the course 
material as well as helped them answer their questions. By doing so, students became more involved in the material details, and in classroom discussions. Students also acknowledged the impact of the questioning process on their learning process.

T1SB-R128: So it help me formulate questions because when writing, we write what we do not understand and we can literally, it's like a diary, you literally write what you do not understand and you try to understand by writing, it is as if you write everything that passes through your mind, then when you hand in your paper to the teacher, and you redo the course, when you hand in your reflective writing and you redo the course on it, well, you've read the chapter and you already know what you don't understand, then your teacher explains, sometimes it can be confusing, because you just said something (in your writing), but (you realize) that's not it, you had an idea in your head, but that's not it, the teacher explains and then, there you realize... but if that's so, how come that this is like this, and this like that? Yes it helps to ask questions.

T2SA-R160: ... I answered my own questions, then after I made the connections and I would ask Mr. Helou in the classroom, or the next day, is that true like that? Or is there no relation? I validated my answers.

T2SB-R161: ... sometimes reflective writing can make us question what we believed, what we think, and it leads us to find answers to questions. 
T2SC-R168: ... I would ask myself questions, if I don't know how to answer those questions, then that means that I did not quite understand the issue, it was pushing me a lot to ask more questions in class, and to want to understand more, and to know that even if I thought I understood, I did not really get it.

Asking questions in their RW even allowed students to question and doubt concepts they thought they had understood but actually didn't. When they were asked to read about the material and to write their own thoughts about it, they were forced in the writing process to connect it to their initial knowledge. During this process, the students discovered that what they just read about was not coherent with their initial knowledge. A mental process is triggered to resolve this lack of coherence. This process includes questioning the initial knowledge and the new one and forces the student into making new connections or to create a new knowledge state more compatible with this newly found doubt. This is the process of the hermeneutic circle (as described in sections $1.1 \quad 1.2$. This process triggered by the RW exercises enables students to make connections between different concepts.

The questioning is also evident in the RW products of the participants. While writing about the subject and its concepts, participants also wrote about their concerns, the connections they made or those they could not make. The following passage from the RW product of a participant shows a conflict between Newton's third law and what they learned about energy in the science course the previous year.

RW-T2SB; A question on Newton's second law:... when the ball exerts a force on the ground is it the ground that exerts a force on the ball that makes it 
bounce? Or is it an accumulation of energy that makes the ball bounce. This is something that I need to clarify.

Some questions were about certain details they read about. The following passages are about space references and their use.

RW-T1SB; On free fall and the sign of gravity:...I don't understand why the gravitational acceleration would be negative on the Y-axis if it's constant and always equal to $9.8 \mathrm{~m} / \mathrm{s}^{2}$.

RW-T1SC: On projectile motion:...I wonder if we have the right to choose our own references in this chapter like we did in the previous one?

The next passage reflects a confusion that relates to the vector nature of velocity.

RW-T2SB: on the revolution of planets: If planets have constant accelerations around the sun, how come their velocities don't change? Every year the Earth completes a full turn around the sun, I don't know.

In another RW task, this participant asked a question and answered it. The RW task was about Newton's second law, she wondered if the law applies for bodies at rest, and concluded that it does: 
RW-T2SB; On applying Newton's second law for bodies at rest: I wonder if it applies to bodies at rest? If we take the example of the book placed on a table the normal force is applied on the book and also the gravitational force...but because the acceleration is zero the resultant force is zero. So of course the law applies for the bodies that are not moving.

\subsection{RW as a guide for the teacher}

While preparing the course, it takes an experienced teacher to anticipate the difficulties of the students. The first time the teacher give a course, one can say that the teacher does not know how the students will react to the different parts of the subject. So that first time, is really a discovery phase, where the teacher learns the reactions, the strengths and weaknesses of the students. The next time the course is taught, the teacher can anticipate the students' needs and difficulties. Even if they are not the same students, the anticipation would still work with some adjustments made by the teacher. RW represents an invaluable source of information for teachers, especially those giving the course for the first time. RW gives the teacher a look at what the students are thinking about, what they've understood and what they need help with. The teacher can plan the course accordingly instead of smart guessing their needs (if the teacher is experienced).

The passages below from the participants' RW can give the teacher a head-start, before the course is covered in class, on what was confusing for them. Even though Newton's first law was mainly understood by students, based on what they wrote in their RW, a confusion was created in its application. In the textbook's statement of the law, it is mentioned that "when no force is applied" the body has a tendency to maintain its state of motion (at rest or uniform 
rectilinear). Some students assumed that when a force is applied (like the friction force), then the body would lose its tendency. These assumptions are documented in their RW given below:

RW-T1SC; On Newton's first law and friction: The force of friction contradicts the First law of Newton, because in situations where the friction force is large, the first law would no longer apply. Whereas, if the friction force is almost non-existent, the first law would work perfectly.

RW-T2SC: On Newton's first law and friction: ...This law contradicts itself. In fact, if we stopped pushing the box, it's supposed to keep on moving at a constant speed, but this one would stop...It is at this moment where the force of friction comes to play: This force would oppose the moving force and it has the same magnitude. So, when we stop pushing the box, it would decelerate and stop.

Such confusions encountered by the students, are made visible to the teacher through the RW products. That would enable the teacher to target these confusions in the classroom discussions or in future course activities.

One source of confusion for many participants was free fall and projectile motion, or simply how bodies fall. This confusion took many forms. Each one of those forms is an indication, and an invitation for the teacher to tackle these sources of confusion during the class discussions that follow the RW exercises. The passages below from the RW of participants show aspects of the confusion. 
RW-T1SC: The gravitational force remains constant on the Earth...How could a body be falling upward?... This concept seems crazy to me. I always thought that gravity was always downward, but I guess it can exert pressure in all directions...

RW-T2SB: The acceleration is determined by the gravitational attraction, which would explain why the acceleration of all bodies is always the same during the fall regardless of their masses. Because the gravitational attraction is the same.

RW-T1SA: ...I understood that at the beginning, when a body falls, it does not have a big speed (at start $\mathrm{v}=0 \mathrm{~m} / \mathrm{s}$ ), but later, as it gets closer to the ground, it accelerates because of the gravitational force.... (Different masses) fall with the same speed, if we remove the air, it's the same force pulling toward the Earth.

RW-T2SA: ...I wonder if the Earth pulls the Sun as much as the Sun pulls on it. In my opinion, I think the force is the same, but the Sun generates more general attraction, I'm really not sure about this, I'm confused... the time to fall down is not really the same as the one to go up.... The velocity of the acceleration is positive when you go up and negative when you go down....this is confusing, it was not like that for the uniformly accelerated rectilinear motion. 
Reflective writing for a better understanding of scientific concepts in high school

RW-T1SB:...I don't want to make a mistake about the difference between the gravitational field and the gravitational force...I'm not quite sure I understand the concepts. They would be clarified when we begin the course.

RW is not only a tool that allows students to anticipate the needs of the course and get them ready to better understand it. It is also a tool that allows the teacher to anticipate the needs of the students and to plan the course to respond to those needs.

\subsection{RW and classroom interactions}

In addition to the impact of RW on students understanding of science concepts, the RW exercises also significantly affected classroom discussions. This was, as a teacher, I have to say, my favourite part of the process of working with RW. Students came to class knowing what the subject of the discussions would be and they were ready with their ideas and their questions. The interviews clearly showed that with RW students were significantly more comfortable in class and more prepared for classroom discussions, which enhances a "flipped classroom":

T2SC-R108: ...the fact that we read the chapter before he explained it, allowed us to better understand in class because we knew what to expect.

T1SB-R110: ...we did a reflective writing, so basically, all the girls of the group read the chapter and then when we meet in class, it is a discussion based on what we have read and we see the perspectives of different girls, we can 
Reflective writing for a better understanding of scientific concepts in high school

answer their questions, then it helps to know if we understood, if we ask the same questions as the others.

T2SB-R173: ... I think the fact that we did reflective writing, reading helped in preparing us for the course, especially that after certain reflective writings the teacher, he brings up some discussion, and it leads us, I think most of the class, to reflect, to participate, to also debate on issues. I think it's interesting, it allowed us to see other perspectives and to understand certain points.

T2SC-R174: ...when the teacher asked us, for example our thoughts on Newton's first law ... it allowed us to know if we really understood... if we made a mistake, it (the class discussion) allowed us to target this error, and with the help of other girls, that allowed us to do, a kind of small debate, really to clarify our ideas, as a whole group, we established a form of understanding, and we all understood together.

Classroom discussions are very common in my classes, and are an essential part of my teaching practices. My students, including participants, are very used to having them in my courses especially that this was their second year with me as their teacher. When RW was first introduced to the students, they were told that classroom discussions will follow every RW exercise. However, what they did not expect, nor did I, was to have a significantly more interesting, more engaging and more rewarding discussions. The difference was felt in the discussions that followed the first RW task. For the tasks that came after, students anticipated better discussions and they actually were better. Many students expressed verbally that they felt a 
change in the quality of the discussions and one participant (an A-student) specifically mentioned that in her interview.

T2SA-R18: Yes definitely, that's the part that I found most useful of reflective writing, that's what I most noticed as differences. As if everyone participated much more in class, and since we have already understood more than half our readings, it was easier for Mr. Helou, he could spend more time on the difficult issues, more complex (issues).

The shift in the quality of the discussions was most evident when the topic was Newton's laws of motion. For example, when Newton's third law was discussed in class in previous years, students would usually be blocked by (1) the fact that there are two forces involved in the interaction between the bodies and (2) that these force are equal in magnitude. The first point, even though much simpler than the second one, was particularly troubling for them when one of the bodies is at rest. Students would argue by saying that they understood that a foot kicking a ball is exerting a force on the ball, but why would the ball be exerting a force on the foot when the ball is not moving toward the foot. The discussion that followed would usually take between 30 and 45 minutes to get the students' heads around the idea that there are two forces (arguments, given almost entirely by students that understood, would be: the foot would hurt when it hits the ball, even if the ball was not moving). The discussions, in both classes, that followed the RW about Newton's third law, did not include any discussion about the presence of two opposite forces. It seemed as if all the students, simply by doing the RW task, were able to identify the presence of these forces. All the discussions were centered around the equal magnitude of the forces and not on the fact that there are two forces. Some students even 
verbally mentioned, while they were discussing the magnitude of the forces, that during their readings the fact of having two forces troubled them, but as they continued to read they were able to resolve the issue. Even the discussion of the magnitude of the forces was more compelling and more efficient. Some students were already convinced of the equal magnitudes and knowing that it will be discussed, they were ready to defend their position with arguments. In this situation alone, significant class time was saved using RW.

In the last quote above by T2SA (R18), the student mentioned the efficiency of the discussions that followed RW and how it saved valuable class time by eliminating avoidable discussions. I explicitly mentioned in the text that she was an A-student, even though its code indicates it, because I believe that there is another discrete advantage to RW in this situation that is worth mentioning. This advantage is derived from the thoughts of A-students (or from any other student who understood the material). One has to imagine the class discussion without RW to appreciate what that A-student is saying. If Newton's third law was discussed in a class without RW, an A-student would realize more quickly the involvement of two forces, but has to wait for the class to catch-up, which would make the discussion redundant and boring for that student. This situation is practically eliminated with RW and participant T2SA realizes that and appreciates it. When asked if she thought the course would be better or worse without RW she answered:

T2SA-R184: ...(before RW) everyone in class had lots of questions on really simple elements, just because they have not read the material before. So Mr. Helou would have to spend, for example, 5 hours of class time to discuss something that would have taken just an hour, something that is really simple. 
Reflective writing for a better understanding of scientific concepts in high school

Reading it before class, we would question ourselves before and we would have less questions (in class). I think it allows us to focus on more important things in class.

Not only did RW save significant class time, but it also makes the time invested more efficient for the teacher and the students, weak and strong. T2SB nicely expresses this idea in her interview:

T2SB-R185: I think that without reflective writing classroom discussions will not be as interesting or as relevant, I think the girls would be less focused on the subject, they would understand less. While with reflective writing, already by doing reflective writing we ask questions and these questions are raised during the discussions and animates them and it's an added asset to the discussion, it makes it more rewarding.

Participant T2SA is not the only one who thought the course would be worse without RW, all the other participants had the same response

T1SA-R181: Worse, if we had not done reflective writing.

T1SB-R182: Worse, but the physics course has never been ... I mean, last year I was a student of Mr. Helou but it was not physics, it was just science courses in general, but I would say that the course would be worse because, nobody knows what it is about before the course starts, but the courses were still good, 
I mean Mr. Helou explains well, only the material would not remain abstract until the end of the course, it would just be new for everyone .

T1SC-R183: I could imagine it quite easily because last year, even before, we didn't do no reflective writing, but classes with Mr. Helou were never not interesting, he is really interesting and passionate about his subject, but without reflective writing it would be worse, because I'll be more confused and mixedup about the material.

T2SB-R185: I think that without reflective writing discussions would not be as interesting or relevant. I think the girls would be less focused on the subject, they would understand less. While with reflective writing, already by doing reflective writing we ask ourselves questions and these questions are raised during the discussions and that animates, it is an added asset to the discussions, they are more rewarding.

T2SC-R186: I think it would be worse for me because the fact that people read the chapter before going in, we already knew what he was going to talk about and if we already had questions we could go and develop them. For example, if we covered the material first in class, before we read the chapter maybe we would have had questions later, and it's better to understand from the beginning instead of being lost for some time and then understand at the end, it's like we understood form the very beginning and we could like, follow him with the examples he gives. That's it. 
Another interesting perspective worth noting is that of a C-student with respect to RW. This last quote shows that RW is not viewed in the same manner by two students with different academic levels. As discussed earlier (section 3.1.3 , an A-student sees RW as a way to make the course and class discussions more efficient by reducing time spent on simple issues. This attitude of A-students actually derives from the fact that they more quickly understand the simpler issues and they want to move on to more discussion worthy parts of the course. The Cstudent sees RW as a reassuring process, in which they get an initial exposure to the subject material enabling them to better follow the teacher in class. They see RW as a tool that reduces confusion during the class discussions, because they are usually confused during those discussions. RW actually helps them understand during class and not after (the way they are used to before RW), as a result they feel that they are engaged in the course and not alienated by it. The A-student sees RW as a tool that reduces the inefficient distribution of class time, thus allowing students and teacher to focus on more important, discussion-worthy matters. These are appealing advantages to RW that benefit teachers and students from all levels.

\subsection{Evolution of how students completed the RW tasks}

Three participant explicitly stated during the interviews that the way they did their RW changed as they completed one task after the other. This change is important because it shows that whenever participants treated RW as a summary they were marked low, especially in the first couple of tasks. As they shifted their writings from a summery-like text to a more impulsively journal-like text their grades on the RW tasks improved.

This evolution in how the students complete their RW tasks can play a significant role in their understanding of physics concepts. For RW to be effective, it needs to force students to 
Reflective writing for a better understanding of scientific concepts in high school

go beyond the simple repetition of what was read in the textbook. RW must bring students to express their ideas about the connections between the concepts. As discussed in chapter 1, the RW task is designed to bring students to question knowledge and make connections. The evaluation rubric that was provided to the students as a guide of what should a RW include, emphasized these points. If the students did not yet develop connections while reading the material in the textbook, then RW's role becomes a trigger to the students to start developing connections. In the case that the students connected concepts while reading, then RW's role would be to enhance connections by asking students to write about them.

The following two quotes show that the students shifted their writings from a summary to a diary-like style of writing.

T1SA-R151: That changed, in the beginning I did summaries, after that I wrote, so I was reading and after that I was writing. Then after, in the last reflective writings, I wrote as I was reading, and everything I did not understand, I wrote about it. I changed my method because it took a long time. It was more efficient to directly read and write so I won't forget.

T1SB-R152: I made reflective writings in two different ways. At first when I started to make reflective writings, I'd open my textbook, then paragraph by paragraph, I wrote the key ideas, so basically, I summarized what I had just read to better understand when it's time to write about my ideas in this chapter. So basically, I'd write a few sentences to summarize a paragraph, like maybe two sentences to summarize a paragraph, and then I'd re-read my summary, to 
Reflective writing for a better understanding of scientific concepts in high school

myself, which was in my own words, so it's easier to understand then I'd react to my summary. So I did not write this summary to give it to the teacher, I was writing it for me. That was the first way that I was writing, then reading this summary, not writing the summary, I wrote my questions about what I had just read, then wrote my reflective writing. I'd re-write the questions and try to answer them. Then the second way, the second way I was doing my reflective writing, it was just not doing summaries. I'd just read paragraph by paragraph, react to the paragraph, and the questions, I'd answer them directly, without summary and then I noticed that my notes on reflective writing were better with the second way. My grades were better when I did not do summaries.

T1SC's comments (below, T1SC-R153) are notable, not only that she mentioned how her way of doing RW evolved, but also described her change of attitude and that of the class with respect to doing the RW tasks. She mentioned that when their grades on RW dropped in the second task, they (she and her classmates) understood that they had to take the work on RW more seriously. Superficial writings, like pure summaries or writings that do not show that they thought about what was read, will not be accepted. She added that, when taken more seriously, the work on RW was actually rewarding to her and enjoyable. Throughout her reply she projected a sense of pride and a sense of achievement. What should be mentioned about this case is that this is a C-student. RW contributed in engaging her to work and achieve in a demanding subject that was previously to her, a source of anxiety. When she was specifically asked whether she was doing it for the grade, she answered that a small amount was for the grade but it was mainly because it helped her better understand and better prepare her for upcoming evaluations. 
T1SC-R153: Ok my steps have changed over the six exercises, from the third one, I think, I've done really well, I was really proud, I was even drawings, sometimes I was not proud of the drawings, it is drawings to explain, for the first two I did not really have a method, usually I'll read, I'll do a summary on the paper, then I'll watch a video about it and when I'll do my reflective writing... there are always concepts that are much more important so I'll address them and every time I approach them, I explain them, then I do a drawing that explains the concept. That was at the end, at the beginning it was just, I write, I write, there was no structure. (Q1: Why have you changed?). I believe that at the beginning, the first (RW) that I did, I didn't take it seriously, but I do not think Mr. Helou was really satisfied with it. Everyone had this idea, I mean the class, I think we didn't take it (RW) seriously, we thought that we could do what we wanted. The girls grades went down in the second reflective writing, we realized that it is much more than we had thought, it's much more than write to write, it was more an analysis and this really helped me personally, it helped me and that's why I changed method. (T1: I'm intrigued, you changed because you were interested or is it because it was graded?). The grade is a part of the motivation but not all of it. I think it's $20 \%$ because of the grade and about $80 \%$ to $75 \%$ because I really thought that if I do that well, for the quiz and the tests that will come, I'll understand better.

She was not the only one to mention the grades of RW. Participant T1SB mentioned in her interview (below T1SB-R134) that it was good to have a grade for RW and without it the students will not do the work. 
T1SB-R134: ...But, as a student I know if the teacher keeps on asking us to read the chapter, the girls won't do it. It's good to have it graded, plus it is difficult to have a bad mark in a reflective writing because it is not necessarily graded on facts, it is only graded on the way which one makes connections. I do not think it's a waste of time, it really helps to understand because it has to do with reading before the course, because we already know what it is, we have an idea.

\subsection{The domain of RW}

There is no such thing as a domain of RW. There are no known restrictions on where RW can be applied. However, RW can be more efficient in some places than in others. It was repeated by participants (in previous quotes of student interviews given in previous parts of this thesis) that RW was most appreciated when students examined Newton's laws of motion. When the participants were asked, in their interviews, to name a good thing and a bag thing about RW, the two A-students had something bad to say about RW. One A-student (T1SA) said that RW took too long to complete, that a paragraph became a page while she was writing. The other Astudent particularly said:

T2SA-R142: ... A bad thing is maybe sometimes, we take what we read word for word. Like for example, I read about the different types of forces, but when I write my reflective writing, the fact that I read it, I'll just repeat what I've read, for example, I read the definition of friction, but then I have it in my head so I rewrote the definition of friction. 
Reflective writing for a better understanding of scientific concepts in high school

She was referring to readings that are just about definitions, with no significant connections that one can make. The RW exercise becomes in this case a redundancy of what was read. This is still however the perspective of an A-student, but I believe it is worth noting. As for naming a good thing about RW, all the students replied with the advantages already mentioned in previous sections.

Another question was about whether or not they would recommend RW. To this question, five of the six participants answered yes and some even went on further to recommend it for other subjects even if it was not required by the teacher (the sixth participant was not asked this question by the interviewer).

T1SB-R212: Yes, I would recommend it (RW), even if it is not required by the teacher, because it helps to understand, not necessarily to write, but it's true that it is always better to write, because I believe when learning, when you hear it, you learn better, when you read it, you learn better and when you write it, you learn even better. So if you can combine all of this it just makes understanding better. So I would recommend it, or at least just read the chapter before.

T1SC-R219: Yes (I would recommend it) it is useful, it will, if you do it well, it will (1) help you understand and (2) increase your average.

T1SA-R220: Yes, I definitely recommend it, even in several subjects. I think it could be useful even in history, for example, read a part then just highlight the essential elements, often they linger, they describe, just remove the essential 
elements, but for example in other subjects I think it might not be possible but I think yes, it is recommended.

T2SB-R221: Yes, I recommend this method, not just in physics but in other subjects, other sciences, perhaps mathematics, history, French, world (she means the subject: Contemporary World), languages. I think it allows us to make connections with what we know, it answers our questions, because I think that when we ask ourselves questions, we trigger this reflection, which can lead us further. It also raises some very interesting discussions.

T2SC-R222: Yes really, maybe it'1l cost them extra time at home, perhaps they will see it as a waste of time, I, at first, I thought it would be a waste of time but in the end, I thought it benefited me especially because, when we come to class, even if you are in class, it's better to be in class and understand what the teacher said instead to being in class and not understanding and being lost, and to think we understand but actually we didn't. When just doing exercises if we think we understand and then we have the wrong answers then we will know that we haven't really understood, and reflective writing enabled us to realize this before the teacher explains the material.

The participants' answer to this particular question clearly shows their appreciation to RW and to its benefits. This is a testimony of the positive impact RW had on their understanding of physics concepts. 


\section{Chapter 4: Conclusion}

In this chapter, conclusions are categorized according to the advantages of using RW. Recommendations on how teachers can use RW are also given. These recommendations are based on this study. Some recommendations and comments (section 4.4 ) came directly from the students of both classes that completed the RW tasks. I had the chance to discuss the impact of RW for about 30minutes in the last session of the physics course in every class. These recommendations and comments were gathered during that exchange.

\subsection{The main contributions of this study}

The interviews with the participants as well as the results of their writing products have clearly shown advantages to the use of RW in high school physics courses. The combination of RW followed by classroom discussions is effective in improving students' understanding of physics concepts as well as improving the classroom environment as a place to learn. In particular:

1) Results of this study replicated those found by using RW at the postsecondary level and expanded them to secondary students.

2) This study detected differences in the attitudes and opinions of students of different academic levels toward RW. It also showed that RW affects students with different academic levels in different ways.

3) This study showed that RW has to be approached and presented differently with secondary students than with postsecondary students. Recommendations to the teacher on how to approach RW with secondary students are detailed in section 4.5 


\subsection{RW and the student}

The purpose of this study was to evaluate how the RW exercises affected the high school students' understanding of physics concepts. The results showed that:

1) The students improved their understanding of physics concepts.

2) Students were able to better connect concepts to one another and to their everyday lives.

3) RW allowed students to generate questions and to answer them. It even allowed them to question what they thought they knew and to improve that knowledge.

4) RW prepared students for the coming lessons. The easy parts of the material were understood by the students during their reading and their RW. They were ready for the difficult parts, in class, with their questions.

5) RW helped the weak student become more involved in the course content and the classroom discussions. It also helped the stronger students become even stronger by pushing further their understanding and how they relate the different parts of the course content.

6) Student highlighted the fact that it took them less time to prepare for evaluations because $\mathrm{RW}$ allowed them to anticipate their questions. They were able to find answers to those questions as the course was given and discussed, instead of having those questions brought up after the course and nearer to the evaluation, which leaves them little or no time to get those questions comfortably resolved.

7) The stress levels of the students were lower with RW. The fact that they understood better, asked better questions, knew what the lesson was going to be about along with the chance to resolve course questions and conflicting ideas before the evaluation. All of 
these factors contributed in having less stressed students, which in return made the course for them more enjoyable.

8) The benefits of RW felt by the students compelled them to change their study habits. They shifted from students who read and understand during and after the course into students who read and understand before and during the course.

\subsection{RW and the classroom environment}

In addition to its impact on the students, RW also affected the classroom dynamics and discussions. Particularly:

1) Because the students knew what the topic of the class discussion was going to be, they were more involved in the discussions that took place. Participants reported that these discussions were more interesting and relevant. Even the discussions' dynamics were more vibrant. Two participants called them "debates". This positive exchange helps the students, who are usually less involved, take a more active part in their learning.

2) Students' preparations due to RW helped in reducing, from class time, the discussions of the simpler aspects of the material which left more time and room to more demanding aspects.

\subsection{Recommendations from the students}

During the last period of the course in every class, I took some time to discuss with all the students the pros and cons of RW. This occurred after all the interviews had been completed. The discussions that took place were very interesting. Many students repeated comments already given by participants. They also added variations of answers and other points that could help guide a teacher interested in using RW. Their contributions are listed here: 
1) One student explicitly recommended that one should do the RW task 2 or 3 days before handing it in. What she noticed was that during those days, her ideas evolved and she went back to her paper and changed things, answered questions and added others. She specified that she was thinking more about the subject, after she wrote the RW than she did before.

2) Numerous students recommended less reading per RW task, they said it allowed them to make better connections when there were fewer things to connect. Their best RW tasks were about Newton's laws because they were divided one law at a time. One student added that when the material to read is too large their writing tend to be more like summaries.

3) One student appreciated that one of the requirements of RW (in the rubric) was to connect concepts to everyday life. She said that the fact she was forced to find the connections helped her understand significantly better.

4) Numerous students said that they appreciated more RW when it was about concepts than when it was about definitions (force of gravity, friction force, normal force...).

I would like to share a good moment that occurred during that exchange with the students. In one class, when I asked if they would use RW in a course where it is not required, all the students answered yes, except one top student (not a participant). When I asked her why she said no to RW, she answered that when she reads, she understand, why should she write about it. Another student (not a participant) answered: "you know, that happened to me too, only when I wrote about it, I discovered that I didn't really understand". At that moment, almost all the students in the class were smiling and nodding their heads, agreeing with what that student (the latter) had just said. 


\subsection{RW and the teacher}

Any benefits from which the students profit, also profit the teacher. All the benefits listed above in this chapter can be counted as benefits for the teacher. What follows is a mixed list of comments and recommendations to teachers interested in using RW in their science courses (or any other course). For what it is worth, with my limited experience with RW, if I had to do it again (the process of this study from the beginning) I would take the following under consideration:

1) RW is a surprisingly simple tool yet a powerful one when it comes to affecting positive change in students' understanding of science and their attitudes towards it. If used conveniently (details of what I believe is a convenient use are given below) it could be a teacher's best friend. It simply promotes understanding and students' involvement in the class and the subject, while increasing classroom time efficiency by allowing the teacher to spend more time on more demanding parts of the material. There are bigger theories and models one can follow to obtain excellent results but they are not as simple as RW. Before my work with Professor Kalman, I was an advocate of reflective thinking, which is mainly generated by classroom discussions. As I mentioned in the previous chapter (section 3.3 ), classroom discussions are a significant part of my teaching practices, and they will continue to be a significant part because of what they bring to the understanding of concepts and of how they relate to one another. RW adds an extra edge to reflective thinking, which is obviously the writing part, without eliminating the discussions. As many participants mentioned (in chapter 3 ) there is a clear advantage to writing one's ideas. The ideas simply become clearer to the individual, more organized. As if writing an idea tames it, transforms it from a chaotic cloud of mixed words and threads into a 
disciplined sequence of connections. That is a major part of understanding and of expert thinking. Reflective thinking is great but reflective writing is better.

2) RW should be followed by classroom discussions on the same topic as the RW exercise. Doing RW does not necessarily mean that the student understood.

3) RW allows the teacher to identify the parts that the students understood less and target those in classroom discussions.

4) For high school student, RW represents an excellent preparation for CEGEP (junior college) and university courses. RW invites students to take charge of their learning and to be prepared for class, two key factors for success in postsecondary studies.

5) When using RW a teacher must pay particular attention to the points listed below. Convenient use of RW amplifies its effect and the following advice and ideas help:

- RW in high school is not your average homework; students will most likely find it weird. A teacher should dedicate time to properly situate RW within the course work and project its benefits to the students. A student convinced that RW helps in understanding will achieve better RW exercises quicker and hopefully better results quicker.

- Dedicate classroom time to clearly show the students what is expected from them in RW. Read samples of RW in class and go through the rubric with them.

- RW should be graded to encourage students to take it seriously, at least in the beginning. As students complete RW exercises and notice that RW actually helps, they will start completing the tasks mainly because RW helps them. (RW will still be graded.) 
- The maturity of students affects their attitudes toward RW. I noticed that secondary five students welcomed RW better than secondary four students, as if the task of RW was weirder for younger students. What might have affected their attitudes is that younger students tend to be more dependent on the teacher, and RW promotes a form of distancing from the teacher leading the way. Younger students felt it was like uncharted territory and they were less secured doing it.

- RW works better when the materials to read are reduced.

- RW works best with debatable concepts/laws (like Newton's laws) and least well with procedural knowledge such as definitions and processes (like vector projection). Simply put, RW works less well when there is little or nothing to talk about. If the content is too simple, the teacher loses the A-students, they will simply consider the RW task as unworthy, as a waste of time.

- Excessive use of RW can be a burden on high school students, especially with their workload in science and in other subjects (homework, lab reports, orals, tests projects...). It would be better to target the conceptual parts of the subject with RW instead of all the parts of the material.

- If you are a hesitating teacher, stop hesitating. Try it.

\subsection{Where do we go from here?}

This study was not designed to measure the impact of RW on high school students' academic performance. Future studies can be designed to assess this impact.

This study detected differences between how an A student views RW and how a C student views it. Differences were also detected (1) in their attitudes toward the subject and how 
Reflective writing for a better understanding of scientific concepts in high school

they interact with it (2) in their attitudes toward the classroom interaction. Future studies can investigate further the impact of RW on students of different academic levels. 


\section{REFERENCES}

Ast, F. (1808). Grundlinien der Grammatik, Hermeneutik und Kritik. Landshut: Jos. Thomann.

Aulls, M. W. (2002). The contributions of co-occurring forms of classroom discourse and academic activities to curriculum events and instruction. Journal of Educational Psychology, 94(3), 520-538.

Austin, L. B., \& Shore, B. M. (1994). The use of concept mapping as an instructional strategy in college level physics. Scientia Paedagogica Experimentalis 31(2), 249-264.

Austin, L. B., \& Shore, B. M. (1993). Concept Mapping of High and Average Achieving Students and Experts. European Journal of High Ability, 4(2), 180-195.

Baird, J. R., \& Northfield, J. R. (1995). Learning from the PEEL experience. School of Graduate Studies, Faculty of Education, Monash University.

Bangert-Drowns, R. L., Hurley, M. M., \& Wilkinson, B. (2004). The Effects of School-Based Writing-to-Learn Interventions on Academic Achievement: A Meta-Analysis. Review of Educational Research, 74(1), 29-58.

Bevilacqua, F., \& Giannetto, E. (1995). Hermeneutics and Science Education: The role of history of science. Science \& Education, 4(2), 115-126.

Borda, E. J. (2007). Applying Gadamer's concept of disposition to science and science education. Science and Education, 16(9-10), 1027-1041.

Britton, J., Burgess, T., Martin, N., McLeod, A., \& Rosen, H. (1975). The development of writing abilities (11-18). London: Macmlllan. 
Bruner, J. S. (1986). Actual minds, possible worlds (Vol. 1). Cambridge: Harvard University Press.

Chi, M. T. H., Feltovich, P. J., \& Glaser, R. (1981). Categorization and Representation of Physics Problems by Experts and Novices. Cognitive Science, 5(2), 121-152.

Chin, C. (2006). Classroom interaction in science: teacher questioning and feedback to students' responses. International Journal of Science Education, 28(11), 1315-1346.

Cisero, C. a. (2006). Does Reflective Journal Writing Improve Course Performance? College Teaching, 54(2), 231-236.

Connolly, P. (1989). Writing and the ecology of learning. Writing to Learn Mathematics and Science, 1-14.

Countryman, J. (1992). Writing To Learn Mathematics: Strategies That Work. Portsmouth, NH: Heinemann.

Creswell, J. W., Hanson, W. E., Clark Plano, V. L., \& Morales, A. (2007). Qualitative Research Designs: Selection and Implementation. The Counseling Psychologist, 35(2), 236-264.

Denzin, N. K., \& Lincoln, Y. S. (2005). The SAGE Handbook of Qualitative Research. Thousand Oaks, CA: Sage.

Drabick, D. A. G., Weisberg, R., Paul, L., \& Bubier, J. L. (2007). Keeping it short and sweet: Brief, ungraded writing assignments facilitate learning. Teaching of Psychology, 34(3), $172-176$.

Dukewich, K. R.., \& Vossen, D. P. (2015). Toward Accuracy, Depth and Insight: How Reflective Writing Assignments Can Be Used to Address Multiple Learning Objectives in 
Small and Large Courses. Collected Essays on Learning and Teaching, 8, 97-110.

Eger, M. (1992). Hermeneutics and science education: An introduction. Science \& Education, 1(4), 337-348.

Eger, M. (1993a). Hermeneutics as an approach to science: Part I. Science \& Education, 2(1), 129.

Eger, M. (1993b). Hermeneutics as an approach to science: Part II. Science \& Education, 2(4), $303-328$.

Elbow, P. (1973). The Doubting Game and the Believing Game-An Analysis of the Intellectual Enterprise. Appendix Essay in Writing Without Teachers. New York: Oxford University Press.

Flavell, J. (1976). Metacognitive aspects of problem solving. The nature of intelligence, 12, $231-235$.

Flyvbjerg, B. (2006). Five Misunderstandings About Case-Study Research. Qualitative Inquiry, $12(2), 219-245$.

Forster, M. (2009). Friedrich Daniel Ernst Schleiermacher. Stanford Encyclopedia of Philosophy, $1-60$.

Fulwiler, T. (1987). The Journal Book., Portsmouth, NH: Boynton/Cook Publishers.

Gadamer, H. G. (1975). Truth and Method. New York, NY: Continuum.

Gadamer, H. G. (2004). Truth and Method. New York, NY: Continuum.

Gallagher, S. (1992). Hermeneutics and education. Albany, NY: SUNY press. 
Reflective writing for a better understanding of scientific concepts in high school

Ginev, D. (1995). Between epistemology and hermeneutics. Science \& Education, 4(2), 147159.

Gunel, M., Hand, B., \& McDermott, M. A. (2009). Writing for different audiences: Effects on high-school students' conceptual understanding of biology. Learning and Instruction, 19(4), $354-367$.

Hewson, P., \& Hewson, M. (1984). The role of conceptual conflict in conceptual change and the design of science instruction. Instructional Science, 13, 1-13.

Huang, X., \& Kalman, C. S. (2012). A Case Study on Reflective Writing. Journal of College Science Teaching, 42(1), 92.

Kalman, C. S., Morris, S., \& Cottin, C. \& Gordon, R. (1999). Promoting conceptual change using collaborative groups in quantitative gateway courses. American Journal of Physics, 67(S1), S45-S51.

Kalman, C. S. (2001). Teaching students to solve quantitative problems in science courses by writing their way into the solution. The Successful Professor Sample Issue, 3-4.

Kalman, C. S. (2008). Successful Science and Engineering Teaching:Theoretical and learning perspectives (Vol. 3). London: Springer.

Kalman, C. S. (2011). Enhancing Students' Conceptual Understanding by Engaging Science Text with Reflective Writing as a Hermeneutical Circle. Science and Education, 20(2), $159-172$.

Kalman, C. S., Aulls, M., Rohar, S., \& Godley, J. (2008). Students Perceptions of Reflective Writing as a Tool for Exploring an Introductory Textbook. Journal of College Science 
Teaching. 37, 74-81

Kalman, C. S., Sobhanzadeh, M., Thompson, R., Ibrahim, A., \& Wang, X. (2015). Combination of interventions can change students' epistemological beliefs. Physical Review Special Topics - Physics Education Research, 11(2), 1-17.

Kalman, J., \& Klaman, C. S. (1996). Writing to learn. American Journal of Physics, 64(7), 954.

Keys, C. W. (1999). Revitalizing instruction in scientific genres: Connecting knowledge production with writing to learn in science. Science Education, 83(2), 115-130.

Khanam, W. N., \& Kalman, C. S. (2016). Implementation and Evaluation of the Course Dossier Methodology. The Canadian Journal for the Scholarship of Teaching and Learning, (To be published).

Krajcik, J., Blumenfeld, P., Marx, R., Bass, K., Fredricks, J., \& Soloway, E. (1998). Inquiry in Project-Based Science Classrooms: Initial Attempts by Middle School Students. Journal of the Learning Sciences, 7(3), 313-350.

Larkin, J., McDermott, J., Simon, D. P., \& Simon, H. A. (1980). Expert and novice performance in solving physics problems. Science 208(4450), 1335-1342.

Larkin, T., \& Budny, D. (2005). Learning styles in the classroom: approaches to enhance student motivation and learning. In 2005 6th International Conference on Inforamtion Technology Based Higher Education and Traning (pp. F4D-1). IEEE.

Lincoln, Y. S., \& Guba, E. G. (1985). Naturalistic Inquiry (Vol. 75). Thousand Oaks, CA: Sage.

Mayer, J., \& Hillman, S. (1996). Assessing students' thinking through writing. The Mathematics Teacher, 89(5), 428. 
Reflective writing for a better understanding of scientific concepts in high school

McDermott, M. (2010). More than writing-to-learn. Science Teacher, 77(1), 32-37.

McDermott, M. A., \& Hand, B. (2010). A secondary reanalysis of student perceptions of nontraditional writing tasks over a ten year period. Journal of Research in Science Teaching, $47(5), 518-539$.

McLeod, S. (1987). Defining writing across the curriculum. WPA: Writing Program Administration 11(1-2), 19-24.

Merriam, S. B. (1998). Qualitative research and case study applications in education. Revised and expanded from. San Francisco, CA: Jossey-Bass Publishers.

Mesec, B. (1998). Uvod v kvalitativno raziskovanje v socialnem delu. Visoka šola za socialno delo.

National Research Council (Ed.). (1996). National Science Education Standards. National Acadamy Press.

Nersessian, N. J. (2008). Mental modeling in conceptual change. In S.Vosniadou (Ed.), International handbook of research on conceptual change (pp. 391-416). New York, NY: Taylor and Francis.

Packer, M. (2010). The science of qualitative research. New York, NY: Cambridge University Press.

Piaget, J. (1978). The development of thought : equilibration of cognitive structures. Oxford: B. Blackwell.

Porter, S. E., \& Robinson, J. C. (2011). Hermeneutics: An introduction to interpretive theory. Grand Rapids, MI: William B. Eerdmans. 
Reflective writing for a better understanding of scientific concepts in high school

Rivard, L. O. P. (1994). A review of writing to learn in science: Implications for practice and research. Journal of Research in Science Teaching, 31(9), 969-983.

Ruddell, R. B., \& Unrau, N. J. (1994). Reading as a meaning-construction process: The reader, the text, and the teacher. In R. B. Ruddell, M. R. Ruddell, \& H. Singer (Eds.), Thoeretical models and processes of reading (pp. 996-1056). Newark, DE: International Reading Association.

Sandoval, W. A. (2005). Understanding students' practical epistemologies and their influence on learning through inquiry. Science Education, 89(4), 634-656.

Schleiermacher, F., \& Frank, M. (1977). Hermeneutik und Kritik (Vol. 211). Frankfurt: Suhrkamp.

Scott, P. (1998). Teacher Talk and Meaning Making in Science Classrooms: a Vygotskian Analysis and Review. Studies in Science Education, 32(1), 45-80.

Shore, B. M. (2009). Giftedness Is Not What It Used to Be, School Is Not What It Used to Be, Their Future, and Why Psychologists in Education Should Care. Canadian Journal of School Psychology, 25(2), 151-169.

Shore, B. M., \& Kanevsky, L. S. (1993). Thinking Process: Being and Becoming Gifted. International Handbook of research and development of giftedness and talent, 1, 133-147.

Soysa, C. K., Dunn, D. S., Dottolo, A. L., Burns-Glover, A. L., \& Gurung, R. A. R. (2013). Orchestrating authorship: Teaching writing across the psychology curriculum. Teaching of Psychology, 40(2), 88-97.

Starman, A. B. (2013). The case study as a type of qualitative research. Journal of Contemporary 
Reflective writing for a better understanding of scientific concepts in high school

Educational Studies/Sodobna Pedagogika, 64(1), 28-43.

Van Zee, E. H., Iwasyk, M., Kurose, A., Simpson, D., \& Wild, J. (2001). Student and teacher questioning during conversations about science. Journal of Research in Science Teaching, $38(2), 159-190$.

van Zee, E. H., \& Minstrell, J. (1997). Reflective discourse: developing shared understandings in a physics classroom. International Journal of Science Education, 19(2), 209-228.

Vygotsky, L. S. (1978). Interaction between learning and development. Mind in Society. The development of higher phsychological processes. Cambridge: Harvard University Press.

White, B. Y., \& Frederiksen, J. R. (1998). Inquiry, modeling and metacognition: Making science accessible to all students. Cognition and Instruction, 16(1), 3-118.

Wood, D., Bruner, J. S., \& Ross, G. (1976). The role of tutoring in problem solving. Journal of Child Psychology and Psychiatry, and Allied Disciplines, 17(2), 89-100.

Yin, R. K. (2014). Case study research : design and methods (5th ed.). Thousand Oaks, CA: SAGE Publications.

Yore, L. D., \& Treagust, D. F. (2006). Current Realities and Future Possibilities: Language and science literacy — empowering research and informing instruction. International Journal of Science Education, 28(2-3), 291-314. 


\section{Appendix A}

Invitation to participate in a research study

Title: Reflective writing for a better understanding of scientific concepts in high school

\section{Dear Student, \\ Dear Parent/Guardian}

Students are being asked to participate in a research study aimed at investigating the impact of reflective writing on students' knowledge of scientific concepts. Reflective Writing is a process during which students are asked to write, in an informal manner, about their ideas and attitudes regarding science concepts and how they relate to one another. Reflective Writing promotes a better understanding of scientific concepts. Their writings are analyzed and compared to their attitudes and opinions toward the subject. These attitudes are probed by interviews prior to the reflective writing exercises and following the reflective writing exercises.

The students' participation in the study will be invaluable in this process and will require them to take part in an interview that will focus on their attitudes and opinions toward reflective writing and scientific concepts. The interview will require a maximum of one hour of the student's time and will take place at the school under the supervision of the school's administration. Should you be interested, we will be glad to share the results of the study with you at its conclusion. To know more about Reflective Writing and how it is positively affecting students' views and skills in learning kindly visit: http://reflectivewriting.concordia.ca/

Principal Investigator:

\section{Joseph El-Helou}

Science and Physics Teacher at Collège Saint-

Marcelline

Graduate student, Department of Physics,

Concordia University

Research Supervisor:

\section{Dr. Calvin Kalman}

\section{Professor}

Department of Physics, Concordia University Montreal, QC H4B 1R6
Tel: (514) 334-9651 ext 300

e-mail: jhelou@marcelline.qc.ca
Tel: (514) 848-2424 x 3284

Fax: (514) 8482828

e-mail: Calvin.Kalman@concordia.ca

Web site:

http://physics.concordia.ca/faculty/ckalman.php

Purpose of the Study:

The goal of the study is to investigate how reflective writing impacts the students' knowledge of scientific concepts.

Description of the Study: 
The participants in the study will be asked to undertake reflective writing tasks and take part in two 20-30 minute long interviews. The interviews will take place in school, outside class time, under the supervision of the schools administration.

What is Experimental in this Study?

None of the interview questions used in this study are experimental in nature. The only experimental aspect of this study is the gathering of information for the purpose of analysis.

Risks or Discomforts:

Although the researchers are not aware of any apparent risks in the study, we understand that you might feel uncomfortable answering all the questions during the interview. Should this situation arise, please discontinue answering the questions either temporarily or permanently and get in touch with Sr. Martine Dalpé-High school principal (srmartine@marcelline.qc.ca) as soon as possible.

Benefits of the Study:

We expect students will benefit from participation in the study since participating in the study will help participants reflect on their own learning and become aware of their personal science-related ideas. We hope that it will enhance students' science study skills and motivation to study science.

Confidentiality:

All the data collected in the study will be strictly confidential and nobody except for the researchers will have access to it. During the study all the data will be stored electronically on a password protected computer on a secure Concordia University server. The data will be erased and destroyed in five years after the completion of the study. The confidentiality will be maintained during the publication of the results of the study: no names or any other personal information will be included in the publications.

Voluntary Nature of Participation:

Participation in this study is voluntary. The student's choice of whether or not to participate will not influence her future relations with the Department of Physics at Concordia University or with her science teacher. If the students decides to participate, she is free to withdraw her consent and to stop her participation at any time without penalty. At any particular point in the study, she may refuse to answer any particular question or stop her participation altogether.

Questions about the Study:

If you have any questions about the research now, please ask. Joseph El-Helou, the Principal Investigator of the study (contact info on Page 1). If you have questions later about the research, you may contact Dr. Calvin Kalman (contact info on page 1).

Sincerely,

Joseph El-Helou 


\section{Appendix B}

\section{CONSENT AGREEMENT}

This is to state that I agree to participate in a program of research being conducted by Joseph ElHelou, graduate student at the Physics Department of Concordia University

\section{A. Purpose}

I have been informed that the purpose of the research is to evaluate the influence of reflective writing on the students' understanding of scientific concepts.

B. Procedures

Students will participate in an interview about how they use reflective writing to better understand scientific concepts.

C. Conditions of Participation

- I understand that I am free to withdraw my consent and discontinue my participation at any time without negative consequences.

- I understand that my participation in this study is confidential (my identity will not be disclosed in any papers published or privately circulated that arise from this study.)

- I I understand that the data from this study may be published.

- I understand the purpose of this study and know that there is no hidden motive of which I have not been informed.

I HAVE CAREFULLY STUDIED THE ABOVE AND UNDERSTAND THIS AGREEMENT. I FREELY CONSENT AND AGREE TO PARTICIPATE IN THIS STUDY.

Student's name:

Class:

Student's signature:

Date:

Parent/Guardian's name:

Parent/Guardian's signature:

Date: 


\section{Appendix C}

\section{The Interview Guide}

1. Do you agree to be interviewed and be asked questions about how your experience was in this research study about Reflective Writing (RW)?

2. What did you expect from reflective writing when you were first introduced to it?

3. Did you usually read course material before going to class? Or did you wait for the teacher to start a specific subject and then you would read about it?

4. Did you usually read the textbook?

○ What made you read the textbook?

○ Is it when you didn't understand what the teacher explained?

○ Is it when you wanted to make sure you've understood?

○ Is it because you are thorough and you didn't like to leave anything unchecked or to chance?

5. What do you usually do when you read something or you hear something in class that does not make sense to you?

○ Do you read some more?

○ Do you ask questions?

- Do you try to relate it to other forms of knowledge that you know?

- Do you try to find similarities with other forms of knowledge you are familiar with?

- Do you let it go and hope to understand it later when the teacher brings it up in class?

- Do you simply let it go and hope never to encounter it again?

6. How do you know that you've understood something you read?

7. How many RW tasks did you accomplish?

8. What do you think of RW? Did you find it easy to do?

9. Did RW help you understand something that was initially unclear for you?

10. Did RW help you improve your understanding of something that was initially partially understood?

11. Do you think you could have understood it without RW?

12. Do you think that RW was a waste of time? 
Reflective writing for a better understanding of scientific concepts in high school

13. Can you name one good thing and one bad thing about RW?

14. Why do you think you've been asked to do RW?

15. How did you do RW?

- Can you describe the steps?

- Did the way you did RW change from one task to the other? Why? What changed?

16. Do you think RW was useful to:

$\circ$ Examine your ideas? How?

- Better grasp what you understood and did not? How?

- Prepare you for classroom debate? How?

17. Did the RW change the way you study or learn things? How?

18. If you were asked to imagine this course without RW, would you imagine it better or worse?

19. Is RW what you expected it to be?

20. Did you find this subject challenging/difficult for you? Why? Did RW help you through it? How?

21. Did you find this subject enjoyable/motivating? Why?

22. How would you rate your overall experience with RW? Would you recommend it? Why? 


\section{Appendix D}

\section{Reflective Writing Guidelines and Rubric}

Many of you may have experience that during discussion with others, you can clarify your ideas. Speaking to others is always helpful to obtain a better understanding. The idea of doing reflective writing is to construct a self-dialogue about what you have read. The main difference between summary and reflective writing is that in a summary you write down what you already have in your mind during your reading, while in doing reflective writing you question what you read and relate it to other concerns.

DON'T just pick up important sentences or ideas from the textbook and give me a list!

To do it, first finish reading the material, at the same time, you may underline, highlight, or even do summarization. Then close your book, and rethink about what you have in your brain, at the same time, write down your rethinking rapidly. Don't pay attention to grammar, it's not formal writing, but jotting. Write down your own understanding of concepts, relationship among those concepts, or even relationship of the material to former chapters and your former knowledge from other disciplines and life experience.

Don't worry if what you are writing is right or not. Marking is not based on that. 


\begin{tabular}{|c|c|c|c|c|c|}
\hline & $\begin{array}{l}\text { Features present } \\
\text { in the reflective- } \\
\text { writing product }\end{array}$ & $\begin{array}{l}\text { Meets criteria } \\
\text { fully }\end{array}$ & $\begin{array}{l}\text { Meets most of } \\
\text { the criteria }\end{array}$ & $\begin{array}{l}\text { Minimally } \\
\text { meets the } \\
\text { criterion }\end{array}$ & $\begin{array}{l}\text { Does not } \\
\text { meet } \\
\text { criterion at } \\
\text { all }\end{array}$ \\
\hline 1 & $\begin{array}{l}\text { Presenting the key } \\
\text { concepts of the } \\
\text { subject as } \\
\text { understood by the } \\
\text { student. }\end{array}$ & $\begin{array}{l}\text { Complete } \\
\text { Does } \\
\text { not copy the } \\
\text { lesson. }\end{array}$ & $\begin{array}{l}\text { Covers all } \\
\text { concepts but } \\
\text { not really in } \\
\text { his/her own } \\
\text { words }\end{array}$ & $\begin{array}{l}\text { Partial coverage } \\
\text { of concepts }\end{array}$ & $\begin{array}{l}\text { No concepts } \\
\text { covered }\end{array}$ \\
\hline 2 & $\begin{array}{l}\text { Describing the } \\
\text { relationship } \\
\text { between the } \\
\text { various concepts }\end{array}$ & $\begin{array}{l}\text { Qualitative } \\
\text { interpretation } \\
\text { used to } \\
\text { compose the } \\
\text { relationship in } \\
\text { the words } \\
\text { of the student. }\end{array}$ & $\begin{array}{l}\text { Surface } \\
\text { description of } \\
\text { Qualitative } \\
\text { interpretation } \\
\text { used to } \\
\text { compose the } \\
\text { relationship }\end{array}$ & $\begin{array}{l}\text { Some attempt } \\
\text { to compose } \\
\text { the relationship. }\end{array}$ & $\begin{array}{l}\text { Not able to } \\
\text { interpret. }\end{array}$ \\
\hline 3 & $\begin{array}{l}\text { Student relates } \\
\text { key concepts to } \\
\text { his/her own life } \\
\text { experiences }\end{array}$ & $\begin{array}{l}\text { Shows clear } \\
\text { understanding } \\
\text { of how the } \\
\text { concepts occur } \\
\text { in everyday } \\
\text { situations }\end{array}$ & $\begin{array}{l}\text { Shows partial } \\
\text { understanding } \\
\text { of how the } \\
\text { concepts occur } \\
\text { in everyday } \\
\text { situations }\end{array}$ & $\begin{array}{l}\text { Mention of } \\
\text { everyday } \\
\text { situations } \\
\text { without any } \\
\text { explanation of } \\
\text { how they relate } \\
\text { to concepts } \\
\text { under study in } \\
\text { current sections }\end{array}$ & $\begin{array}{l}\text { No } \\
\text { relationships } \\
\text { to his/her } \\
\text { own life } \\
\text { experiences } \\
\text { are given. }\end{array}$ \\
\hline 4 & $\begin{array}{l}\text { Student } \\
\text { formulates his/her } \\
\text { own question(s). }\end{array}$ & $\begin{array}{l}\text { Student } \\
\text { realizes that } \\
\text { there are } \\
\text { concepts in the } \\
\text { textbook that } \\
\text { s/he does not } \\
\text { understand } \\
\text { and elaborates } \\
\text { a clear } \\
\text { question }\end{array}$ & $\begin{array}{l}\text { Student sets } \\
\text { out a question } \\
\text { that is not } \\
\text { clearly } \\
\text { formulated }\end{array}$ & $\begin{array}{l}\text { Student notes } \\
\text { the difference } \\
\text { between his/her } \\
\text { own ideas and } \\
\text { the ones in the } \\
\text { textbooks } \\
\text { without any } \\
\text { discussion }\end{array}$ & $\begin{array}{l}\text { No questions } \\
\text { given }\end{array}$ \\
\hline
\end{tabular}




\section{Appendix E}

Transcripts of the interviews

\begin{tabular}{|c|c|c|c|c|}
\hline & Questions & Student & Answers & $\mathrm{Nb}$ \\
\hline \multirow[t]{6}{*}{1} & \multirow{6}{*}{$\begin{array}{l}\text { Êtes-vous } \\
\text { d'accord d'être } \\
\text { interrogé sur } \\
\text { votre expérience } \\
\text { avec l'écriture } \\
\text { réflexive (ER)? }\end{array}$} & T1SA & Oui & 1 \\
\hline & & T1SB & Oui & 2 \\
\hline & & $\mathrm{T} 1 \mathrm{SC}$ & Oui & 3 \\
\hline & & T2SA & Oui & 4 \\
\hline & & T2SB & Oui & 5 \\
\hline & & $\mathrm{T} 2 \mathrm{SC}$ & Oui & 6 \\
\hline \multirow[t]{6}{*}{2} & \multirow{6}{*}{$\begin{array}{l}\text { Qu'attendiez- } \\
\text { vous de l'ER } \\
\text { lorsqu'on vous en } \\
\text { a parlé pour la } \\
\text { première fois? }\end{array}$} & T1SA & $\begin{array}{l}\text { Que ça m'aiderai à plus comprendre la matière, comme } \\
\text { à établir des liens entre, non seulement le chapitre là } \\
\text { où on est, comme le chapitre sur lequel on écrit } \\
\text { l'écriture réflexive mais aussi comme les autres avant. }\end{array}$ & 7 \\
\hline & & T1SB & $\begin{array}{l}\text { Je m'attendais à faire des lectures sur les chapitres } \\
\text { qu'on allait voir dans les cours futur, dans le fond nous } \\
\text { préparer au cours et de comprendre la matière avant } \\
\text { que le professeur l'explique. }\end{array}$ & 8 \\
\hline & & $\mathrm{T} 1 \mathrm{SC}$ & $\begin{array}{l}\text { Pour être honnête pas vraiment grand-chose parce que } \\
\text { je croyais que c'était juste un projet qu'on allait peut- } \\
\text { être pas continuer qu'on n'allait pas vraiment suivre } \\
\text { jusqu'à la fin donc je ne m'attendais pas à grand-chose. }\end{array}$ & 9 \\
\hline & & T2SA & $\begin{array}{l}\text { Moi j'avais l'impression que comme... on devait lire } \\
\text { un chapitre au complet et après écrire juste ce qui nous } \\
\text { vient dans la tête après avoir lu ce chapitre... donc } \\
\text { j'avais l'impression que c'est juste exprimé dans mots } \\
\text { ce qu'on a compris de la matière dans le chapitre }\end{array}$ & 10 \\
\hline & & T2SB & $\begin{array}{l}\text { La première fois que M. Helou nous en a parlé, ça m'a } \\
\text { intéressé, j'ai trouvé ça intéressant, et je m'attendais à } \\
\text { ce qu'il nous donne, effectivement, des travaux un lien } \\
\text { avec cette écriture réflexive. }\end{array}$ & 11 \\
\hline & & $\mathrm{T} 2 \mathrm{SC}$ & $\begin{array}{l}\text { Alors, au début j'avais un peu peur, je ne comprenais } \\
\text { pas trop le contexte de ça, mais au fur et à mesure, et } \\
\text { avec les explications de M. Helou et les critères } \\
\text { d'évaluation, ça nous a permis de nous faire une } \\
\text { meilleure idée, et au fur à mesure je devenais meilleur } \\
\text { dans les Écritures réflexives }\end{array}$ & 12 \\
\hline \multirow[t]{3}{*}{3} & \multirow{3}{*}{$\begin{array}{l}\text { Aviez-vous } \\
\text { l'habitude de lire }\end{array}$} & T1SA & Non & 13 \\
\hline & & T1SB & Non & 14 \\
\hline & & T1SC & Non définitivement pas & 15 \\
\hline
\end{tabular}




\begin{tabular}{|c|c|c|c|c|}
\hline & $\begin{array}{l}\text { le matériel du } \\
\text { cours avant } \\
\text { d'aller en classe? }\end{array}$ & T2SA & $\begin{array}{l}\text { Non, c'est justement ça comme... j'ai aimé l'écriture } \\
\text { réflexive parce que ça m'a poussé à lire donc quand } \mathrm{M} \text {. } \\
\text { Helou parlait en classe je comprenais ce qu'il } \\
\text { expliquait et je peux déjà poser des questions par } \\
\text { rapport à ma lecture avant.... parce que d'habitude je } \\
\text { lisais après et cela me mélangeait (lire après } \\
\text { l'explication) }\end{array}$ & 16 \\
\hline & & T2SB & $\begin{array}{l}\text { Parfois oui je lis le manuel surtout quand je ne } \\
\text { comprends pas un certain sujet. D'habitude, je dirais } \\
\text { que oui je lis le matériel du cours. }\end{array}$ & 17 \\
\hline & & $\mathrm{T} 2 \mathrm{SC}$ & Non je n'avais pas l'habitude & 18 \\
\hline & (Si la réponse est & T1SA & Oui & 19 \\
\hline & $\begin{array}{l}\text { non) Vous } \\
\text { attendez que }\end{array}$ & T1SB & $\begin{array}{l}\text { Je commence à lire après que le professeur a } \\
\text { commencé la matière pour comprendre mon devoir. }\end{array}$ & 20 \\
\hline & l'enseignant & T1SC & Oui & 21 \\
\hline & commence un & T2SA & & 22 \\
\hline & cuiet snécifigue & T2SB & & 23 \\
\hline & $\begin{array}{l}\text { sujet specitique, } \\
\text { puis vous } \\
\text { commencerez à } \\
\text { lire sur ce sujet? }\end{array}$ & $\mathrm{T} 2 \mathrm{SC}$ & $\begin{array}{l}\text { Non parce que d'habitude quand il vient il parle au fur } \\
\text { à mesure des chapitres il va parfois faire des } \\
\text { PowerPoint et non pas nécessairement aller dans le } \\
\text { manuel il va plus extraire une synthèse }\end{array}$ & 24 \\
\hline 4 & Aviez-vous & T1SA & Non & 25 \\
\hline & $\begin{array}{l}\text { l'habitude de lire } \\
\text { le manuel? }\end{array}$ & T1SB & $\begin{array}{l}\text { Avant qu'on commence à faire l'écriture réflexive dans } \\
\text { le cours de physique je n'avais pas l'habitude de lire le } \\
\text { manuel mais une fois qu'on a commencé à faire } \\
\text { l'écriture réflexive, on devait lire le manuel pour faire } \\
\text { l'écriture. On va dire qu'on faisait un chapitre sur la } \\
\text { lumière, je n'avais pas l'habitude de lire le chapitre } \\
\text { avant que le prof l'explique en classe. Avant l'écriture } \\
\text { réflexive je lisais le manuel pour faire les devoirs, } \\
\text { pour voir les exemples. }\end{array}$ & 26 \\
\hline & & $\mathrm{T} 1 \mathrm{SC}$ & $\begin{array}{l}\text { Oui, pour me préparer pour les interrogations et les } \\
\text { examens. }\end{array}$ & 27 \\
\hline & & T2SA & $\begin{array}{l}\text { Je le lisais avant l'interrogation donc je faisais la } \\
\text { récapitulation du cours dans mes notes et ensuite je } \\
\text { lisais le manuel, une différente version de la matière }\end{array}$ & 28 \\
\hline & & T2SB & $\begin{array}{l}\text { Je pense que ça dépend du contexte, parfois je lis le } \\
\text { manuel avant le cours, pour comprendre le cours, pour } \\
\text { me préparer au cours. Ce qui me pousse à lire parfois, } \\
\text { une fois le cours a été donné, et je ne comprends pas } \\
\text { une certaine sujet je relis le manuel, ça peut m'aider à } \\
\text { comprendre. }\end{array}$ & 29 \\
\hline & & $\mathrm{T} 2 \mathrm{SC}$ & $\begin{array}{l}\text { Pour les interrogations, Oui. (Question : Qu'est ce qui } \\
\text { te pousse à lire dans le manuel?). C'est juste pour } \\
\text { approfondir ma compréhension, avec les PowerPoint }\end{array}$ & 30 \\
\hline
\end{tabular}




\begin{tabular}{|c|c|c|c|c|}
\hline & & & $\begin{array}{l}\text { ce que je comprends c'est déjà, ma compréhension est } \\
\text { déjà bonne, mais j'aimerais plus la compléter avec } \\
\text { d'autres exemples du manuel }\end{array}$ & \\
\hline & \multirow{6}{*}{$\begin{array}{l}\text { Est-ce vous lisez } \\
\text { quand vous ne } \\
\text { comprenez pas ce } \\
\text { que l'enseignant a } \\
\text { expliqué? }\end{array}$} & T1SA & Oui & 31 \\
\hline & & T1SB & & 32 \\
\hline & & T1SC & $\begin{array}{l}\text { Non la plupart du temps je vais juste sur des sites } \\
\text { internet comme « Allô prof » et des trucs du genre, } \\
\text { parce que je trouve que le manuel n'est pas vraiment } \\
\text { simplifié par rapport aux sites }\end{array}$ & 33 \\
\hline & & T2SA & $\begin{array}{l}\text { Oui en quelque sorte, je le lisais après pour } \\
\text { comprendre }\end{array}$ & 34 \\
\hline & & T2SB & & 35 \\
\hline & & T2SC & Oui & 36 \\
\hline & \multirow{6}{*}{$\begin{array}{l}\text { Est-ce vous lisez } \\
\text { pour s'assurer } \\
\text { que vous avez } \\
\text { bien compris? }\end{array}$} & T1SA & Oui & 37 \\
\hline & & T1SB & & 38 \\
\hline & & T1SC & Oui & 39 \\
\hline & & T2SA & Oui en quelque sorte oui & 40 \\
\hline & & T2SB & Oui parfois & 41 \\
\hline & & $\mathrm{T} 2 \mathrm{SC}$ & Oui & 42 \\
\hline & \multirow{6}{*}{$\begin{array}{l}\text { Est-ce parce que } \\
\text { vous êtes } \\
\text { méticuleuses et } \\
\text { vous ne voulez } \\
\text { rien laisser au } \\
\text { hasard? }\end{array}$} & T1SA & Je lisais pour les interrogations et les évaluations & 43 \\
\hline & & T1SB & & 44 \\
\hline & & T1SC & $\begin{array}{l}\text { Je ne crois pas que je suis méticuleuse et je ne veux } \\
\text { rien laisser au hasard, je me fie plus sur les résumés } \\
\text { qu'on fait en classe et aux sites internet }\end{array}$ & 45 \\
\hline & & T2SA & $\begin{array}{l}\text { Non c'est plutôt juste en général pour avoir une autre } \\
\text { version de la matière }\end{array}$ & 46 \\
\hline & & T2SB & & 47 \\
\hline & & T2SC & Oui j'aime tout étudier et tout savoir & 48 \\
\hline \multirow[t]{6}{*}{ 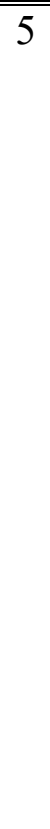 } & \multirow{6}{*}{$\begin{array}{l}\text { Qu'est-ce que } \\
\text { vous faites } \\
\text { habituellement } \\
\text { quand vous lisez } \\
\text { quelque chose ou } \\
\text { vous entendez } \\
\text { quelque chose } \\
\text { dans la classe qui } \\
\text { n'a pas de sens } \\
\text { pour vous? }\end{array}$} & T1SA & $\begin{array}{l}\text { Ça dépend de quelle matière mais je lève la main pour } \\
\text { poser une question à l'enseignant }\end{array}$ & 49 \\
\hline & & T1SB & $\begin{array}{l}\text { Quand c'est en classe, je demande plus d'informations } \\
\text { par rapport à ça au professeur, si jamais je n'ai pas } \\
\text { encore compris je lis le manuel par moi-même, et si } \\
\text { jamais je ne comprends pas je demande au professeur } \\
\text { un temps supplémentaire durant sa disponibilité pour } \\
\text { voir si je pourrais comprendre mieux. }\end{array}$ & 50 \\
\hline & & T1SC & D'habitude je demande au professeur & 51 \\
\hline & & T2SA & $\begin{array}{l}\text { Premièrement je me demande des questions, je } \\
\text { demande est-ce qu'ils ont raison? Est-ce que c'est moi } \\
\text { qui a raison? pourquoi je pense comme ça? Et après je } \\
\text { vais demander ma question à M. Helou. }\end{array}$ & 52 \\
\hline & & T2SB & $\begin{array}{l}\text { Je pose une question... je m'interroge sur cette } \\
\text { question }\end{array}$ & 53 \\
\hline & & $\mathrm{T} 2 \mathrm{SC}$ & $\begin{array}{l}\text { Alors, soit je me rappelle des paroles de M. Helou ou } \\
\text { je prends un exemple moi-même, ou soit je vais lever }\end{array}$ & 54 \\
\hline
\end{tabular}


Reflective writing for a better understanding of scientific concepts in high school

\begin{tabular}{|c|c|c|c|}
\hline & & $\begin{array}{l}\text { ma main pour qu'il m'explique et habituellement } \\
\text { quand il va m'expliquer je vais comprendre. }\end{array}$ & \\
\hline \multirow[t]{6}{*}{ Lisez-vous plus? } & T1SA & Oui & 55 \\
\hline & T1SB & & 56 \\
\hline & T1SC & Dans le manuel non mais d'autre part & 57 \\
\hline & T2SA & & 58 \\
\hline & T2SB & Non, plutôt je vais poser une question au professeur & 59 \\
\hline & $\mathrm{T} 2 \mathrm{SC}$ & Oui & 60 \\
\hline \multirow{6}{*}{$\begin{array}{l}\text { Vous posez des } \\
\text { questions? }\end{array}$} & T1SA & Oui & 61 \\
\hline & T1SB & & 62 \\
\hline & T1SC & & 63 \\
\hline & T2SA & & 64 \\
\hline & T2SB & & 65 \\
\hline & $\mathrm{T} 2 \mathrm{SC}$ & & 66 \\
\hline \multirow{6}{*}{$\begin{array}{l}\text { Vous essayez de } \\
\text { le relier à d'autres } \\
\text { informations que } \\
\text { vous connaissez? }\end{array}$} & T1SA & Oui & 67 \\
\hline & T1SB & & 68 \\
\hline & $\mathrm{T} 1 \mathrm{SC}$ & $\begin{array}{l}\text { Je ne crois pas, comme explicitement, mais plus } \\
\text { comme, pour moi-même, dans ma tête }\end{array}$ & 69 \\
\hline & T2SA & $\begin{array}{l}\text { Oui, j'essaye de voir qu'est-ce qu'on est en train de } \\
\text { faire maintenant, c'est quoi la matière et je me } \\
\text { demande est-ce qu'il y a un rapport logique avec } \\
\text { justement, par exemple une équation qu'on a vu avant } \\
\text { ou bien un principe, et après si je ne vois pas le rapport } \\
\text { entre les deux je demande à M. Helou. Monsieur } \\
\text { Helou répond aux questions. }\end{array}$ & 70 \\
\hline & T2SB & $\begin{array}{l}\text { C'est sûr que dans certaines matières je lirai avec le } \\
\text { quotidien, et la vie quotidienne, ce que je connais, et } \\
\text { aussi faire des liens ça nous aide à assimiler les } \\
\text { connaissances et à comprendre ce qu'on nous enseigne }\end{array}$ & 71 \\
\hline & $\mathrm{T} 2 \mathrm{SC}$ & $\begin{array}{l}\text { Oui, quand parfois même dans les écritures réflexives } \\
\text { il nous dit de faire des liens avec la réalité } \\
\text { d'aujourd'hui et des exemples de chaque jour. Pour } \\
\text { approfondir notre compréhension }\end{array}$ & 72 \\
\hline \multirow{6}{*}{$\begin{array}{l}\text { Vous essayez de } \\
\text { trouver des } \\
\text { similitudes avec } \\
\text { d'autres } \\
\text { informations que } \\
\text { vous êtes } \\
\text { familiers avec? }\end{array}$} & T1SA & Oui & 73 \\
\hline & T1SB & & 74 \\
\hline & T1SC & $\begin{array}{l}\text { C'est ça, non pas explicitement comme j'ai déjà dit } \\
\text { c'est plus pour moi-même. }\end{array}$ & 75 \\
\hline & T2SA & & 76 \\
\hline & T2SB & & 77 \\
\hline & $\mathrm{T} 2 \mathrm{SC}$ & & 78 \\
\hline \multirow{3}{*}{$\begin{array}{l}\text { Vous la laissez } \\
\text { tomber et vous } \\
\text { espérez la }\end{array}$} & T1SA & Oui (rire) & 79 \\
\hline & T1SB & & 80 \\
\hline & T1SC & $\begin{array}{l}\text { Habituellement si je ne comprends pas, je prendrai } \\
\text { l'initiative et je demanderai au prof }\end{array}$ & 81 \\
\hline
\end{tabular}


Reflective writing for a better understanding of scientific concepts in high school

\begin{tabular}{|c|c|c|c|c|}
\hline & comprendre & T2SA & & 82 \\
\hline & lorsque & T2SB & & 83 \\
\hline & $\begin{array}{l}\text { l'enseignant } \\
\text { l'amène en } \\
\text { classe? }\end{array}$ & $\mathrm{T} 2 \mathrm{SC}$ & Non & 84 \\
\hline & Vous la laissez & T1SA & Non (rire) & 85 \\
\hline & tomber et vous & T1SB & & 86 \\
\hline & $\begin{array}{l}\text { espérez ne jamais } \\
\text { la revoir de }\end{array}$ & $\mathrm{T} 1 \mathrm{SC}$ & $\begin{array}{l}\text { Cela m'est déjà arrivé mais ce n'est pas quelque chose } \\
\text { que je fais comme routine }\end{array}$ & 87 \\
\hline & a & T2SA & & 88 \\
\hline & & T2SB & & 89 \\
\hline & & T2SC & Non & 90 \\
\hline 6 & $\begin{array}{l}\text { Comment saviez- } \\
\text { vous que vous }\end{array}$ & T1SA & $\begin{array}{l}\text { Si je suis capable de l'expliquer à quelqu'un d'autre ou } \\
\text { bien de le dire à voix haute }\end{array}$ & 91 \\
\hline & $\begin{array}{l}\text { avez compris } \\
\text { quelque chose } \\
\text { que vous avez lu? }\end{array}$ & T1SB & $\begin{array}{l}\text { Si je peux faire des liens avec les autres aspects que } \\
\text { j'ai lue comme on va dire dans un chapitre on ne parle } \\
\text { pas d'une seule chose, on parle de plusieurs choses, si } \\
\text { je peux faire un lien entre chaque chose que j'ai lue, } \\
\text { puis je peux le visualiser, comme faire un dessin qui } \\
\text { l'explique, je sais que j'ai compris. }\end{array}$ & 92 \\
\hline & & T1SC & $\begin{array}{l}\text { Habituellement si je lis quelque chose et après ça le } \\
\text { professeur va l'expliqué en classe et si ça correspond à } \\
\text { ce que je pensais, c'est comme ça que je sais que j'ai } \\
\text { compris }\end{array}$ & 93 \\
\hline & & T2SA & $\begin{array}{l}\text { Si je fais un problème après puis, si quelqu'un pose des } \\
\text { questions après et je réponds bien, et si j'ai } \\
\text { l'impression que je comprends ce que le professeur dit } \\
\text { après. }\end{array}$ & 994 \\
\hline & & T2SB & $\begin{array}{l}\text { Souvent, quand je lis, une fois habituellement, quand } \\
\text { j'ai bien compris le sens de la phrase, quand je ne } \\
\text { comprends pas je relis la phrase j'essaie de } \\
\text { comprendre, parfois s'il y a une image, pour voir si } \\
\text { cette image rejoins bien d'autres explications, J'essaye } \\
\text { aussi de faire des liens pour comprendre ce que je ne } \\
\text { comprends pas }\end{array}$ & 95 \\
\hline & & $\mathrm{T} 2 \mathrm{SC}$ & $\begin{array}{l}\text { Quand je vais aller refaire des exercices ou refaire des } \\
\text { exercices de révisions, parce que je les ai bon sans } \\
\text { nécessairement utiliser mes notes, c'est à ce moment-là } \\
\text { que je vais comprendre (savoir que j'ai compris) }\end{array}$ & 96 \\
\hline 7 & Combien de & T1SA & 6 & 97 \\
\hline & tâches d'ER & T1SB & Peut-être 5 à peu près? & 98 \\
\hline & avez-vous & $\mathrm{T} 1 \mathrm{SC}$ & 5-6 probablement & 99 \\
\hline & accomplis? (les & T2SA & Peut-être 5 , autour de 5. & 100 \\
\hline & & T2SB & $4-5$ & 101 \\
\hline
\end{tabular}




\begin{tabular}{|c|c|c|c|c|}
\hline & $\begin{array}{l}\text { élèves ont } \\
\text { accompli } 6 \text { ER) }\end{array}$ & T2SC & Je pense que nous avons fait 5 & 102 \\
\hline \multirow[t]{4}{*}{8} & \multirow[t]{4}{*}{$\begin{array}{l}\text { Que pensez-vous } \\
\text { de l'ER? L'aviez- } \\
\text { vous trouvé facile } \\
\text { à faire? }\end{array}$} & T1SA & $\begin{array}{l}\text { Des chapitres oui, des chapitres non. Il y a des } \\
\text { chapitres que puisque on avait déjà fait, il y avait des } \\
\text { liens (avec ce qu'on lisait) c'était plus facile, oui il y } \\
\text { avait des liens, des choses comme ça. Mais il y a des } \\
\text { chapitres on n'avait jamais vu ça, donc là, ça a été plus } \\
\text { difficile parce qu'il y avait plus de choses que je ne } \\
\text { comprenais pas. }\end{array}$ & 103 \\
\hline & & T1SB & $\begin{array}{l}\text { Ah oui, Je pense que c'est quelque chose assez facile à } \\
\text { faire, on li le manuel, moi la manière que je fonctionne } \\
\text { quand je fais une écriture réflexive je lis le manuel } \\
\text { puis en même temps je prends des notes sur chaque } \\
\text { paragraphe genre, puis ensuite en faisant les notes } \\
\text { j'écris, si jamais il y a une question que je n'ai pas } \\
\text { compris je l'écris directement sur la feuille puis quand } \\
\text { je fais mon écriture réflexive je récapitule, puis } \\
\text { j'essaie de répondre aux questions que je n'avais pas } \\
\text { compris, parfois je ne peux y répondre et parfois je } \\
\text { peux y répondre, mais c'est justement ça le but de } \\
\text { l'écriture réflexive. }\end{array}$ & 104 \\
\hline & & T1SC & $\begin{array}{l}\text { Ok, pour être honnête, la première fois que j'ai fait } \\
\text { l'écriture réflexive, j'ai écrit n'importe quoi, je croyais } \\
\text { que c'était juste, je ne sais pas la notion été comme, je } \\
\text { crois qu'elle était comme un peu bizarre, quand tu } \\
\text { écris à propos de ce que tu lis et le professeur va te } \\
\text { noter à propos de tes pensées. Je trouvais ça bizarre } \\
\text { qu'un professeur puisse comme, me noter à ce que je } \\
\text { pense la matière. La première fois que je l'avais fait } \\
\text { j'avais écrit n'importe quoi et cela m'avait donné à } 8 \\
\text { sur } 10 \text { et moi j'étais comme OK, La deuxième fois je } \\
\text { crois que j'ai mal fait, non j'ai définitivement mal fait, } \\
\text { et la troisième fois j'ai commencé à prendre sa } \\
\text { beaucoup plus au sérieux parce que j'ai réalisé que cela } \\
\text { m'aide à comprendre. Elle n'est pas tout le temps } \\
\text { facile, ça dépend de la matière ça dépend de ce qui est } \\
\text { abordé }\end{array}$ & 105 \\
\hline & & T2SA & $\begin{array}{l}\text { Au premier regard j'étais comme, je me disais ha! } \\
\text { encore un travail, il faut écrire il faut lire au complet, } \\
\text { mais après, ça m'a vraiment aidée, je me disais, quand } \\
\text { je lisais, je me disais : ok ça, je ne comprends pas mais } \\
\text { il va sûrement l'expliquer en classe, ok cette partie-là, } \\
\text { je la comprends mais j'ai une question justement } \\
\text { méticuleuse sur un point mais je peux la poser en } \\
\text { classe, au lieu de lire à la fin du cours et après se dire }\end{array}$ & 106 \\
\hline
\end{tabular}




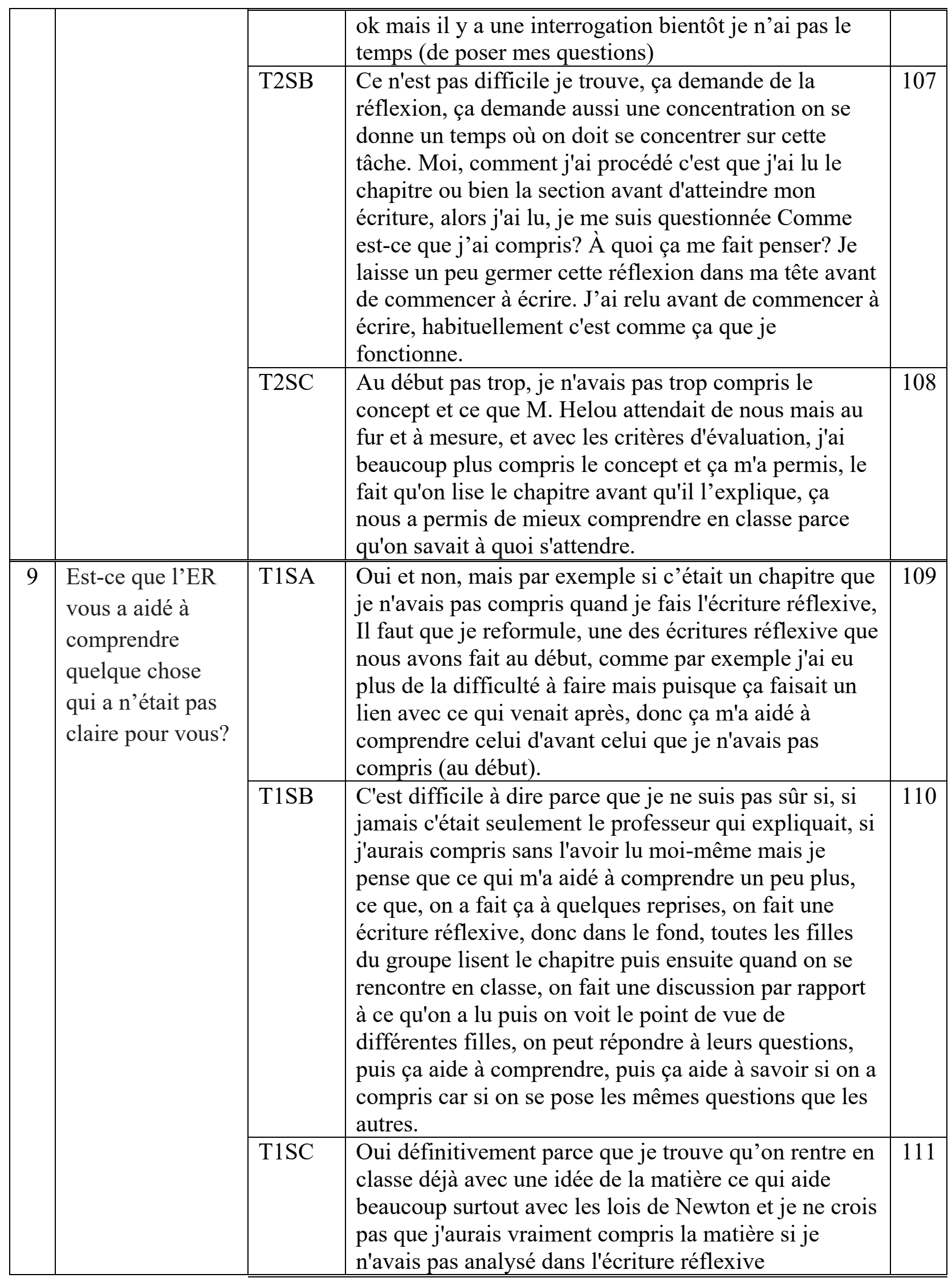




\begin{tabular}{|c|c|c|c|c|}
\hline & & T2SA & $\begin{array}{l}\text { Parce que à mon avis l'écriture réflexive m'a était plus } \\
\text { utile quand on a fait les trois lois de Newton et je me } \\
\text { dis qu'il y a peut-être que je ne les aurais pas si bien } \\
\text { compris si je n'aurais pas lu, si je n'aurais pas fait } \\
\text { l'écriture réflexive. Parce que ça me poussait à me } \\
\text { questionner puis à donner des exemples de la vie } \\
\text { quotidienne et ça m'a poussé à essayer de comprendre } \\
\text { mais peut-être si je ne l'aurais pas fait, je n'aurais pas } \\
\text { compris. }\end{array}$ & 1112 \\
\hline & & T2SB & $\begin{array}{l}\text { Oui, moi je trouve que ça aide l'écriture réflexive pour } \\
\text { assimiler des idées et aussi sa m'aide quand le prof } \\
\text { donne le cours après avoir fait mon écriture réflexive, } \\
\text { parce que j'ai, premièrement j'ai lu, et c'est sûr que tu } \\
\text { comprends mieux quand tu as déjà lu avant et aussi } \\
\text { lorsque le prof explique, j'ai fait le lien avec ce que j'ai } \\
\text { lu, alors oui ça m'a aidé à mieux comprendre }\end{array}$ & 113 \\
\hline & & $\mathrm{T} 2 \mathrm{SC}$ & $\begin{array}{l}\text { Oui, surtout pour les lois de Newton, on devait les lire } \\
\text { à la maison, faire l'écriture réflexive et par la suite on } \\
\text { l'expliquait en classe, ça m'a permis de beaucoup } \\
\text { mieux comprendre, comme ça m'aidait comme } \\
\text { référence. }\end{array}$ & 114 \\
\hline \multirow[t]{10}{*}{10} & \multirow{6}{*}{$\begin{array}{l}\text { Est-ce que l'ER } \\
\text { vous a aidé à } \\
\text { améliorer votre } \\
\text { compréhension } \\
\text { de quelque chose } \\
\text { qui était } \\
\text { initialement } \\
\text { partiellement } \\
\text { compris? }\end{array}$} & T1SA & Oui & 115 \\
\hline & & T1SB & $\begin{array}{l}\text { Ahmm, je dirais que oui parce que monsieur Helou } \\
\text { explique quand même bien, mais, peut-être qu'en lisant } \\
\text { le manuel par moi-même je n'aurais été capable de le } \\
\text { comprendre seule, donc avec les explications en } \\
\text { classe, oui, mais peut-être que si je ne les avais pas, } \\
\text { non. }\end{array}$ & 116 \\
\hline & & T1SC & $\begin{array}{l}\text { Oui définitivement l'écriture réflexive m'a permis à } \\
\text { mieux comprendre, je crois aussi que si je n'avais pas } \\
\text { écrit l'écriture réflexive j'aurais plus de la difficulté à } \\
\text { comprendre. J'aurais compté plus sur ce que le } \\
\text { professeur dit en classe, mais je crois que c'était bien } \\
\text { que j'avais déjà une idée. }\end{array}$ & 117 \\
\hline & & T2SA & & 118 \\
\hline & & T2SB & & 119 \\
\hline & & T2SC & $\begin{array}{l}\text { Oui, ça m'a aidée surtout pour les lois de Newton, ça } \\
\text { m'a mélangé entre elles (les lois) ça me mélangeait, } \\
\text { mais au fur et à mesure, parce que l'écriture réflexive, } \\
\text { c'est comme si on écrivait notre pensée, alors ça m'a } \\
\text { permis de mieux comprendre. }\end{array}$ & 120 \\
\hline & \multirow{4}{*}{$\begin{array}{l}\text { Pensez-vous que } \\
\text { vous auriez pu } \\
\text { comprendre sans } \\
\text { l'ER? }\end{array}$} & T1SA & Pas aussi bien & 121 \\
\hline & & T1SB & & 122 \\
\hline & & T1SC & & 123 \\
\hline & & T2SA & $\begin{array}{l}\text { Définitivement j'aurais pu comprendre mais j'aurais } \\
\text { peut-être moins de aise. }\end{array}$ & 124 \\
\hline
\end{tabular}




\begin{tabular}{|c|c|c|c|c|}
\hline & & T2SB & $\begin{array}{l}\text { Oui ça aurait été possible (de comprendre) mais ça } \\
\text { n'aurait pas été pas assimilé aussi vite, parce que pour } \\
\text { moi les matières scientifiques et mathématiques, ça me } \\
\text { prend du temps avant de comprendre, et l'écriture } \\
\text { réflexive a accéléré ce processus de compréhension, et } \\
\text { oui ça m'a aidé }\end{array}$ & 125 \\
\hline & & $\mathrm{T} 2 \mathrm{SC}$ & Non je ne pense pas & 126 \\
\hline \multirow[t]{4}{*}{11} & \multirow{4}{*}{$\begin{array}{l}\text { Est-ce que l'ER } \\
\text { vous a aidé à } \\
\text { formuler des } \\
\text { questions? }\end{array}$} & T1SA & $\begin{array}{l}\text { Ça m'a permis de savoir les choses que je ne } \\
\text { comprenais pas, ça m'a permis d'organiser la façon } \\
\text { avec laquelle je vois la matière. }\end{array}$ & 127 \\
\hline & & T1SB & $\begin{array}{l}\text { Je dirai que oui, c'est sûr car si on ne connaît pas } \\
\text { l'essence du chapitre, on va dire qu'on n'a jamais vu } \\
\text { les lois de Newton avant, on avait trois lois de Newton } \\
\text { puis quand on a vu par exemple la troisième, et la } \\
\text { deuxième c'est plus facile de comprendre la première } \\
\text { que lorsqu'on commence avec la troisième loi sans } \\
\text { qu'on voit les autres parce que elle ont toutes un lien. } \\
\text { Donc ça m'a aider à formuler des questions parce que } \\
\text { en écrivant, on écrit ce qu'on ne comprend pas puis on } \\
\text { peut littéralement, c'est comme un journal, t'écris } \\
\text { littéralement ce que tu ne comprends pas et tu essayes } \\
\text { de comprendre en écrivant c'est comme si tu écris tous } \\
\text { ce qui te passe par la tête, puis quand tu remets ta } \\
\text { feuille au prof et on refait le cours, quand tu remets } \\
\text { ton écriture réflexive et on fait le cours là-dessus, tu as } \\
\text { lu le chapitre et tu sais déjà ce que tu ne comprends } \\
\text { pas ensuite le professeur l'explique, parfois ça peut } \\
\text { être mélangeant parce que tu viens juste de dire } \\
\text { quelque chose mais tu avais une idée dans la tête, mais } \\
\text { ce n'est pas ça, le professeur l'explique et ensuite là tu } \\
\text { te rends compte mais si ça est comme ça, comment ça } \\
\text { se fait que ça et comme ça. Oui ça aide à poser des } \\
\text { questions }\end{array}$ & 128 \\
\hline & & T1SC & $\begin{array}{l}\text { Oui parce que je crois que surtout notre manuel de } \\
\text { physique n'est pas le manuel le plus idéal je crois } \\
\text { même que le professeur le sait il le dit souvent. Parce } \\
\text { que parfois ce n'est pas vraiment clair tu lis quelque } \\
\text { chose, et tu tournes quelques pages, et les choses se } \\
\text { contredisent et ça te permet vraiment de se questionner } \\
\text { sur la matière et formuler des questions }\end{array}$ & 129 \\
\hline & & $\overline{\mathrm{T} 2 \mathrm{SA}}$ & $\begin{array}{l}\text { Oui définitivement, ça c'est la partie que j'ai trouvé la } \\
\text { plus utile de l'écriture réflexive, c'est ça que j'ai le plus } \\
\text { remarqué comme différences. Comme tout le monde } \\
\text { participait beaucoup plus en classe et vu qu'on a déjà } \\
\text { compris plus que la moitié en lisant M. Helou avait }\end{array}$ & 130 \\
\hline
\end{tabular}




\begin{tabular}{|c|c|c|c|c|}
\hline & & & $\begin{array}{l}\text { plus de facilité, il pouvait plus s'attarder sur les } \\
\text { questions difficiles, plus complexes }\end{array}$ & \\
\hline & & T2SB & $\begin{array}{l}\text { Peut-être pas aider à formuler, peut-être plus à les } \\
\text { poser directement, parce que c'est sûr que quand je lis } \\
\text { je me pose déjà des questions, alors l'écriture réflexive } \\
\text { m'a juste aidé à les mettre dans des mes mots et à les } \\
\text { écrire et aussi à y répondre, parce que parfois, souvent } \\
\text { quand j'ai des questions quand je lis, je ne trouve pas } \\
\text { de réponses précises, exactes, immédiates, mais } \\
\text { l'écriture réflexive à force que j'ai réfléchi, j'ai pu } \\
\text { relire des passages et y répondre. Donc je dirais } \\
\text { qu'elle m'a aidé à formuler des questions et à y } \\
\text { répondre aussi. }\end{array}$ & 131 \\
\hline & & $\mathrm{T} 2 \mathrm{SC}$ & $\begin{array}{l}\text { Oui, surtout parce que même dans les écritures } \\
\text { réflexives j'écrivais des questions, comme si je me } \\
\text { questionnais moi-même, et par la suite je répondais à } \\
\text { moi-même à mes questions alors, ce qui m'aidait de } \\
\text { répondre à mes propres questions. T2: ''est-ce que ça } \\
\text { t'a aidé à poser des questions en classe ou que tu } \\
\text { espérais que quelqu'un pose ses questions à ta place?', } \\
\text { D’habitude, je ne pense pas que les personnes vont } \\
\text { poser des questions à ma place, parce qu'il y a } \\
\text { plusieurs questions et j'aime les poser moi-même, et si } \\
\text { je ne comprends pas je continue avec une autre } \\
\text { question ou je demande à l'enseignant d'approfondir ce } \\
\text { qu'il vient de me dire }\end{array}$ & 132 \\
\hline 12 & $\begin{array}{l}\text { Pensez-vous que } \\
\text { l'ER était une } \\
\text { perte de temps? }\end{array}$ & T1SA & $\begin{array}{l}\text { Non parce que premièrement si on n'avait pas fait } \\
\text { l'écriture réflexive, je n'aurais pas lu le manuel donc } \\
\text { puisqu'on fait l'écriture réflexive on est obligé de lire } \\
\text { le manuel, ça m'a permis d'avoir une idée de ce qu'on } \\
\text { va discuter en classe avant de commencer le cours. } \\
\text { Donc ouais c'est ça, donc ce n'était pas une perte de } \\
\text { temps. Et le faite qu'elle est évaluée nous pousse à } \\
\text { mettre plus d'effort. }\end{array}$ & 133 \\
\hline & & T1SB & $\begin{array}{l}\text { Non personnellement je ne pense pas que c'est une } \\
\text { perte de temps mais il y a certaines filles dans la classe } \\
\text { qui savait que c'était moi qui faisait l'entrevue de } \\
\text { l'écriture réflexive puis elles m'ont dit de dire qu'elle } \\
\text { trouvait que c'est une perte de temps personnellement } \\
\text { je trouve que une écriture réflexive ça aide à } \\
\text { comprendre puis aussi il y a une (fille) en particulier } \\
\text { qui m'a dit que si le professeur devrais savoir que si } \\
\text { jamais il veut qu'on lise un chapitre dans le manuel il } \\
\text { faut juste nous le demander sans faire un travail noté } \\
\text { dessus. Mais en tant qu'élève je sais que si le } \\
\text { professeur nous demande de lire le chapitre plusieurs }\end{array}$ & 134 \\
\hline
\end{tabular}




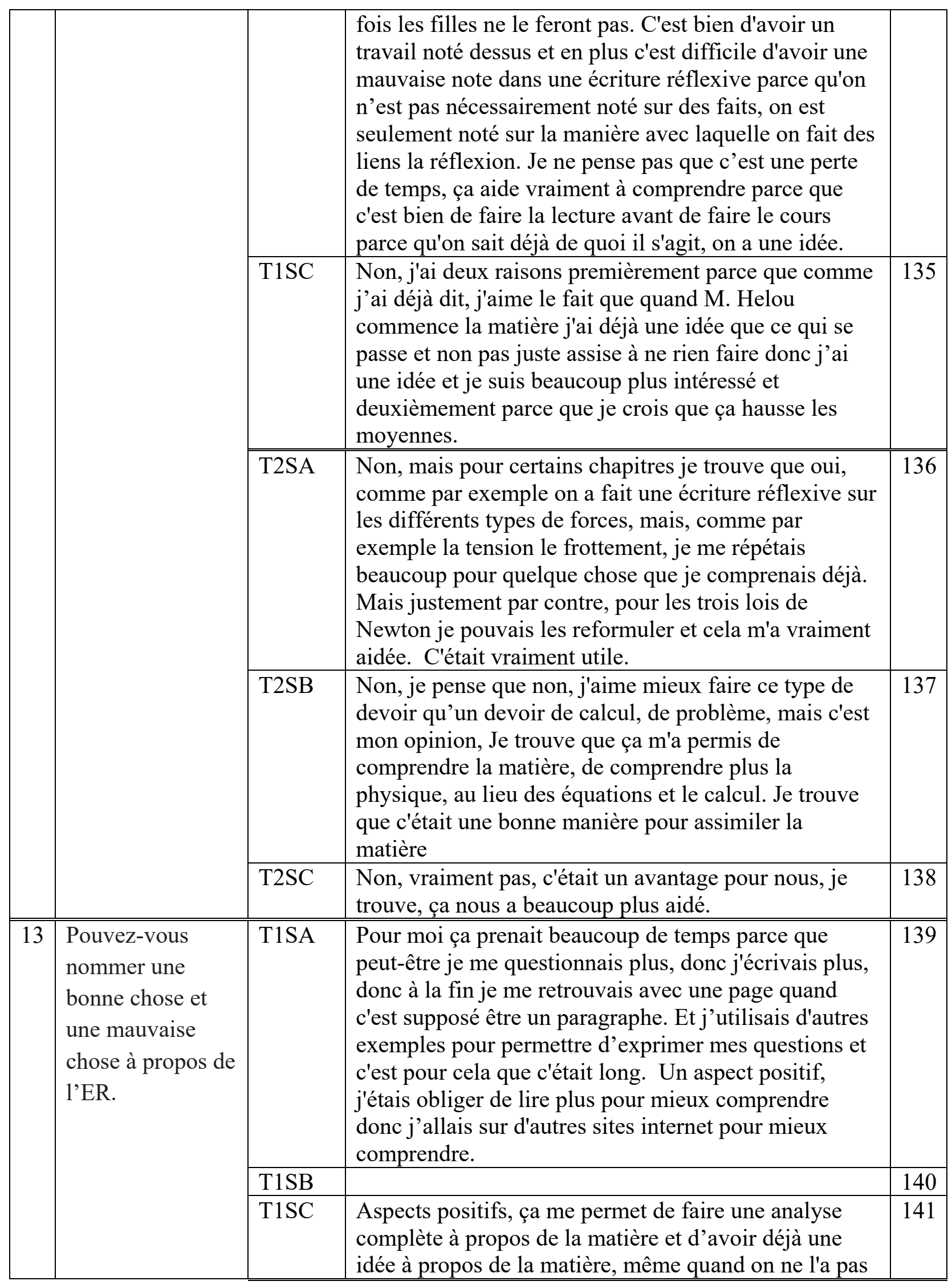




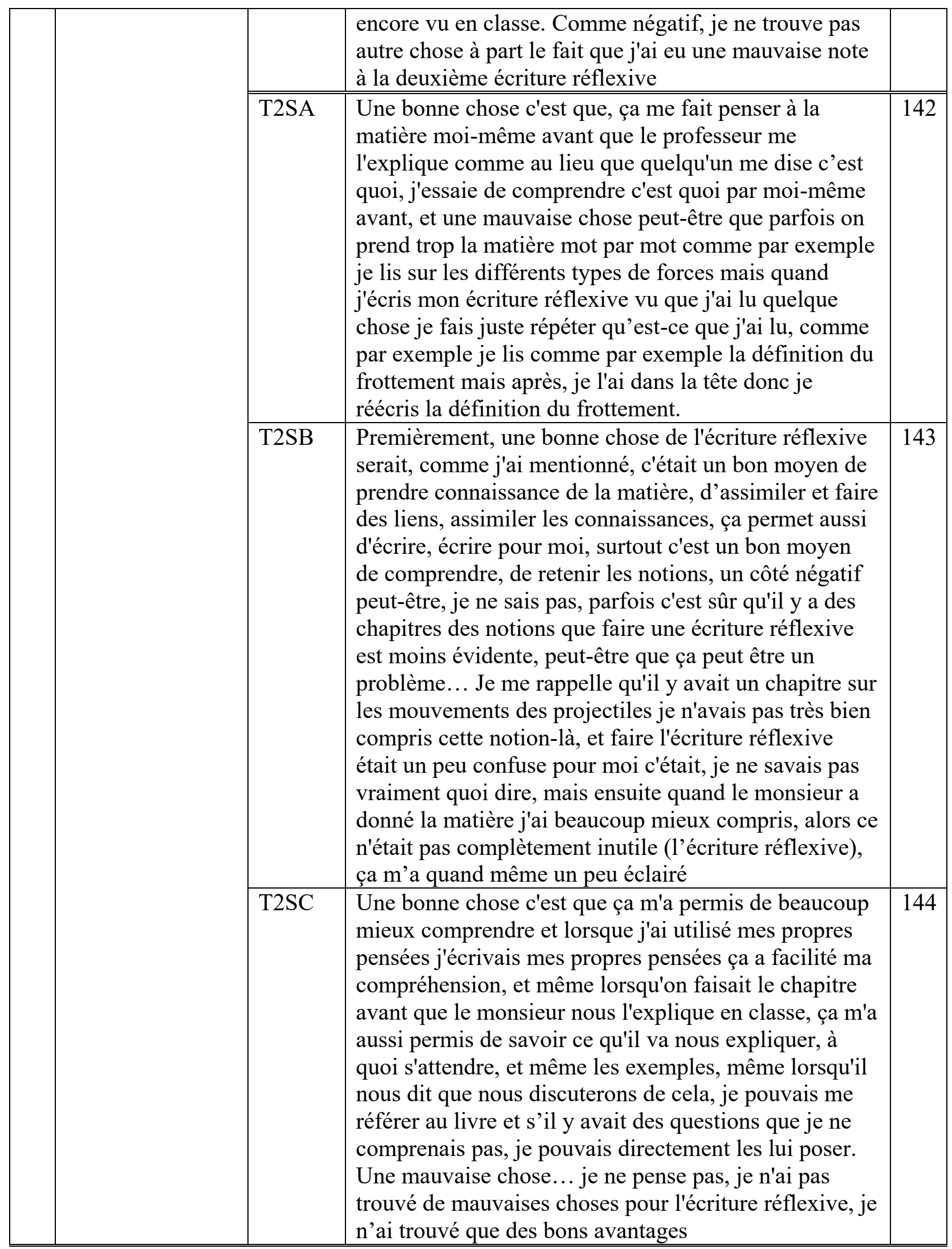




\begin{tabular}{|c|c|c|c|c|}
\hline \multirow[t]{6}{*}{14} & \multirow{6}{*}{$\begin{array}{l}\text { Pourquoi pensez- } \\
\text { vous que vous } \\
\text { avez été invité } \\
\text { (comme classe) à } \\
\text { faire l'ER? }\end{array}$} & T1SA & $\begin{array}{l}\text { Je crois que M. Helou ne voulait pas qu'on arrive sans } \\
\text { rien savoir sur la matière, sans avoir aucune idée de la } \\
\text { matière, comme être dans l'ombre. }\end{array}$ & 145 \\
\hline & & T1SB & $\begin{array}{l}\text { Je pense qu'on était juste invité à faire des écritures } \\
\text { réflexives pour aider à notre compréhension. Moi } \\
\text { personnellement je ne pense même pas qu'il y a un } \\
\text { côté négatif à l'écriture réflexive, j'ai parlé pour les } \\
\text { autres, mais moi personnellement non, je trouve que } \\
\text { ça aide à comprendre ça aide à réfléchir sur la } \\
\text { question. C'est juste pour, avant un cours on peut tous } \\
\text { interagir ensemble, que ça soit pas une matière trop } \\
\text { abstraite pour les filles de la classe parce qu'elles ont } \\
\text { déjà lu sur le sujet, donc ça permet de juste faire } \\
\text { avancer le cours plus rapidement. }\end{array}$ & 146 \\
\hline & & T1SC & $\begin{array}{l}\text { Parce que M. Helou le fait dans sa classe je crois que } \\
\text { cela l'a inspiré comme professeur parce qu'il la fait } \\
\text { comme étudiant. }\end{array}$ & 147 \\
\hline & & T2SA & $\begin{array}{l}\text { Moi je pense que peut-être on voulait voir si, } \\
\text { justement on avait bien fait l'écriture réflexive et si on } \\
\text { devrait l'instaurer obligatoirement si on veut, ou bien } \\
\text { améliorer la méthode d'enseignement en l'ajoutant au } \\
\text { programme }\end{array}$ & $\bar{~} 148$ \\
\hline & & T2SB & $\begin{array}{l}\text { Le monsieur a raconté que lui, en tant qu'étudiant, il a } \\
\text { fait cet exercice d'écriture réflexive, et lui il a dit que } \\
\text { ça lui a aidé et qu'il trouvait ça intéressant et ça lui a } \\
\text { aidé à assimiler des notions et c'est pour cela qu'il a } \\
\text { décidé de d'essayer avec nous et il voulait essayer cette } \\
\text { nouvelle façon d'apprentissage. Aussi je pense que les } \\
\text { résultats qui ont découlé de cette écriture réflexive } \\
\text { étaient positifs. Mais pour moi, ça m'a aidé à } \\
\text { comprendre. }\end{array}$ & 149 \\
\hline & & T2SC & $\begin{array}{l}\text { Parce que je trouve qu'on pose beaucoup de questions } \\
\text { dans la classe, on est quand même curieux, on veut } \\
\text { toujours en savoir plus, savoir le pourquoi du } \\
\text { pourquoi, et d'autres exemples. }\end{array}$ & 150 \\
\hline \multirow[t]{2}{*}{15} & \multirow[t]{2}{*}{$\begin{array}{l}\text { Comment avez- } \\
\text { vous fait l'ER? }\end{array}$} & T1SA & $\begin{array}{l}\text { Ça a changer au cours, au début je faisais des résumés } \\
\text { après ça j'écrivais donc je lisais et après ça j'écrivais. } \\
\text { Puis après, dans les dernières écritures réflexives, je } \\
\text { n'ai pas fait de résumé mais j'ai écrit au fur et à mesure } \\
\text { que je lisais, et tout ce que je ne comprenais pas je } \\
\text { l'écrivais. J'ai changé de méthode parce que ça a pris } \\
\text { beaucoup de temps. C'était plus efficace de lire et } \\
\text { directement écrire ce que je pensais sinon j'oublie. }\end{array}$ & 151 \\
\hline & & T1SB & $\begin{array}{l}\text { J'ouvre mon manuel j'ai les écritures réflexives de } \\
\text { deux manières différentes. Au début quand je } \\
\text { commençais à faire des écritures réflexives j'ouvrai }\end{array}$ & 152 \\
\hline
\end{tabular}




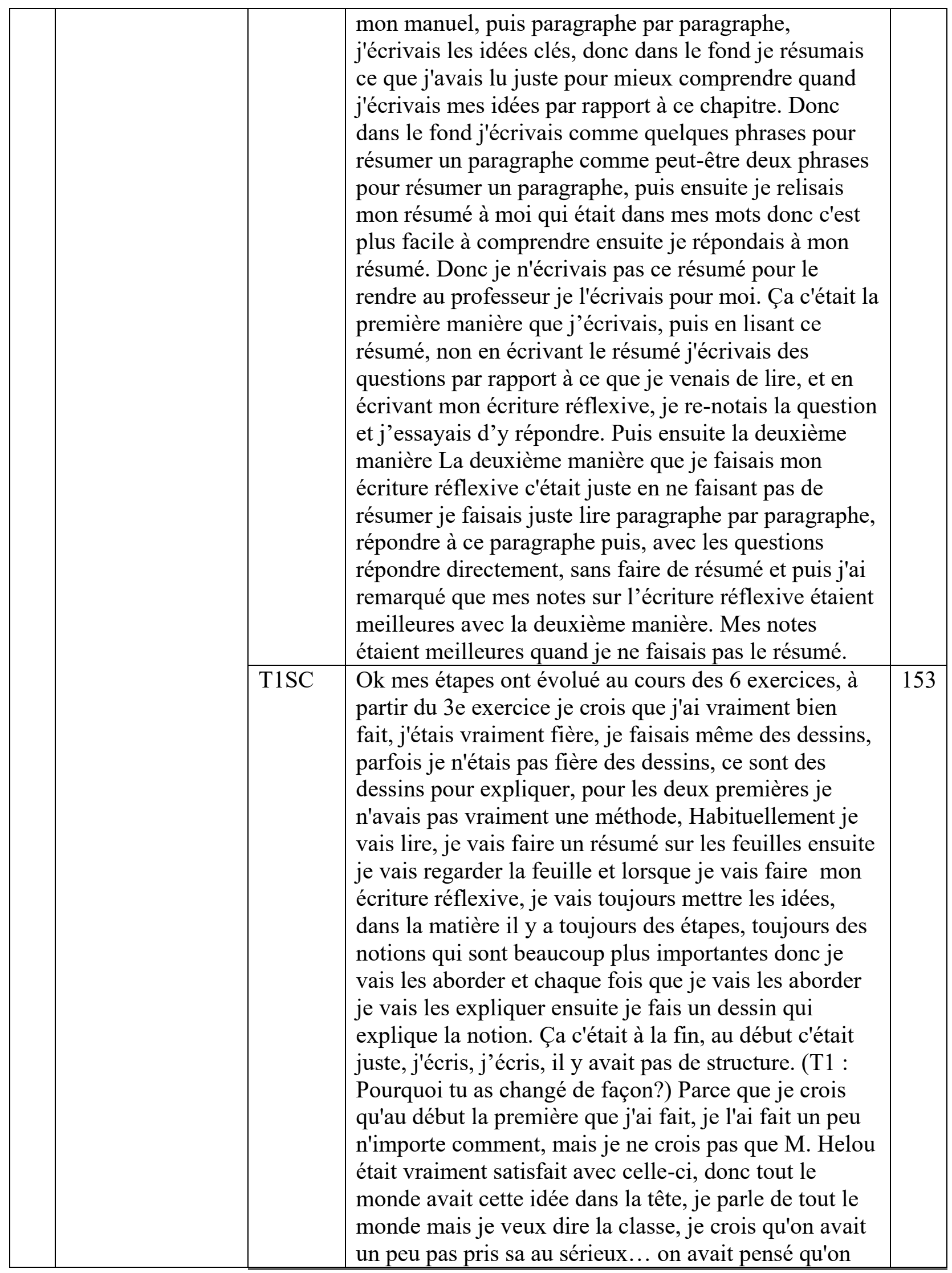




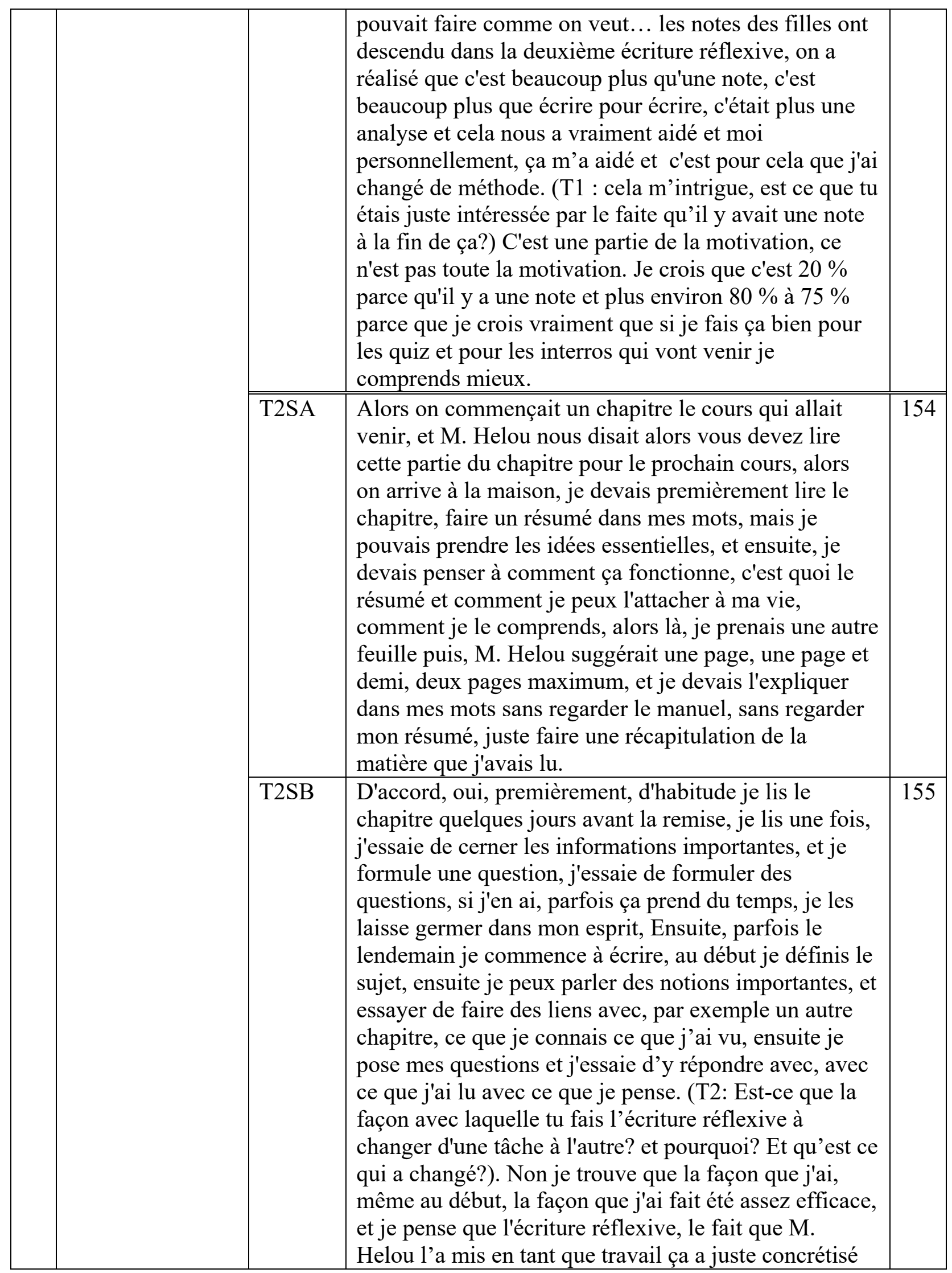




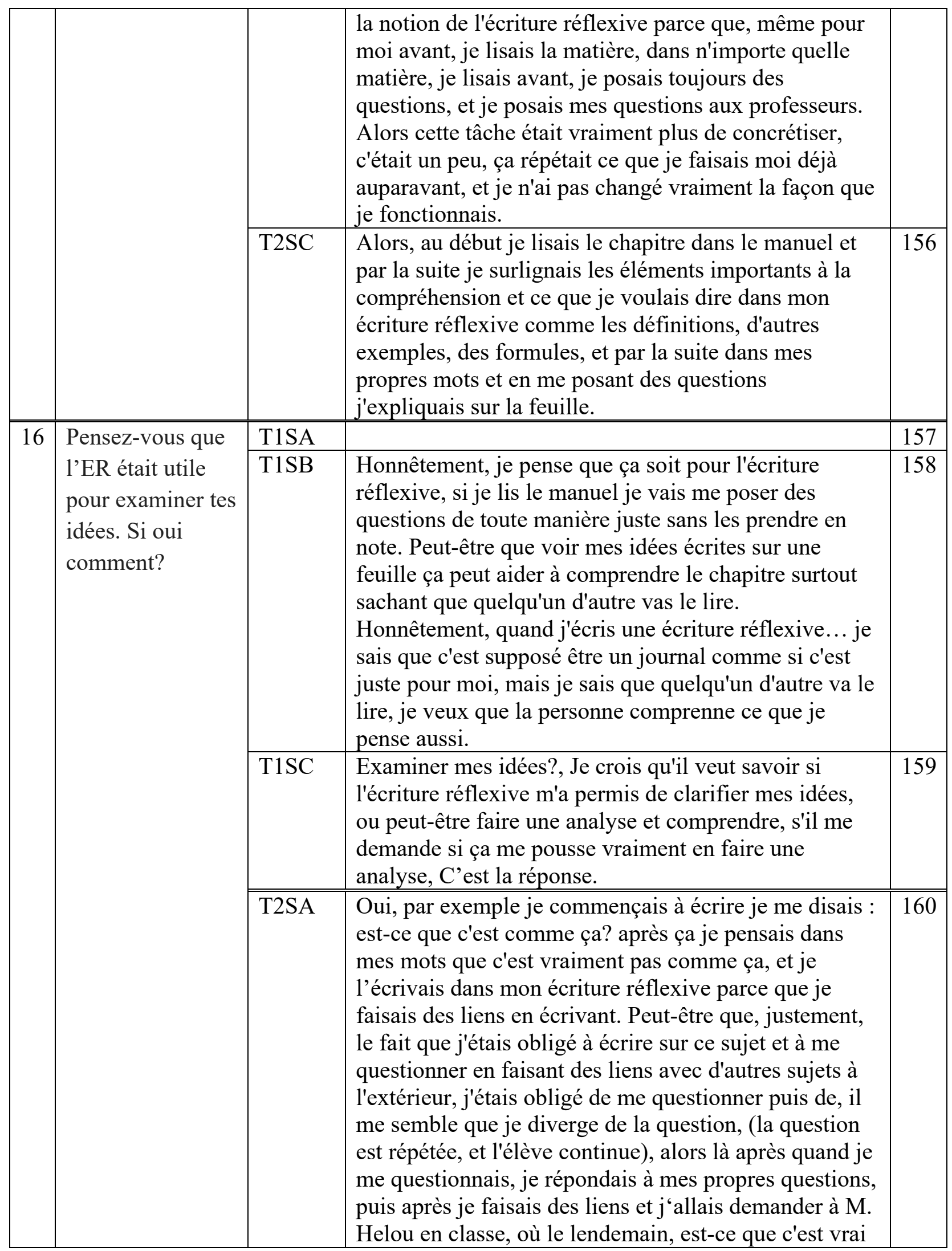




\begin{tabular}{|c|c|c|c|}
\hline & & $\begin{array}{l}\text { comme ça où ça n'a aucun rapport. Je validais mes } \\
\text { réponses }\end{array}$ & \\
\hline & T2SB & $\begin{array}{l}\text { Parfois oui, je ne sais pas si il y a une question } \\
\text { particulière, une écriture réflexive en particulier, peut- } \\
\text { être que, oui il y a une écriture réflexive qui parfois } \\
\text { contredit une idée qu'on avait, et bien ça nous } \\
\text { perplexe, et parfois l'écriture réflexive peut mettre en } \\
\text { question ce que nous on pense, et ça nous mène à } \\
\text { trouver la réponse, à se poser des questions }\end{array}$ & 161 \\
\hline & $\mathrm{T} 2 \mathrm{SC}$ & Non je suis toujours resté avec la même méthode & 162 \\
\hline \multirow{4}{*}{$\begin{array}{l}\text { Pensez-vous que } \\
\text { l'ER était utile } \\
\text { pour mieux saisir } \\
\text { ce que vous avez } \\
\text { compris ou non? } \\
\text { Comment? }\end{array}$} & T1SA & $\begin{array}{l}\text { Oui parce que j'écrivais par rapport à ce que je ne } \\
\text { comprenais pas bien ce que j'ai compris ça me permet } \\
\text { d'organiser mes idées }\end{array}$ & 163 \\
\hline & T1SB & $\begin{array}{l}\text { Je dirais que oui ça aide à mettre mes idées en place. } \\
\text { Si jamais je ne faisais pas l'écriture réflexive, peut-être } \\
\text { que je me poserai la question et passé à autre chose, } \\
\text { mais l'écriture réflexive me force à y penser et essayer } \\
\text { de répondre à mon propre questionnement. }\end{array}$ & 164 \\
\hline & T1SC & $\begin{array}{l}\text { Oui définitivement parce que je crois que quand, } \\
\text { habituellement je ne demande pas beaucoup de } \\
\text { questions en classe, en physique ou je ne réponds pas } \\
\text { beaucoup parce que, premièrement, je ne sais pas en } \\
\text { physique ce n'est pas un cours où je réponds beaucoup, } \\
\text { je ne sais pas vraiment, une idée, surtout en physique } \\
\text { c'est tellement abstrait, tu n'as aucune idée de qu'est-ce } \\
\text { que tu comprends et qu'est-ce que tu ne comprends } \\
\text { pas. Des fois je suis juste là, assise et je me demande } \\
\text { si c'est juste moi ou c'est toute la classe qui ne } \\
\text { comprends pas, et ça c'était comme une attitude } \\
\text { initiale, j'avais peur d'avoir l'air stupide parce que je ne } \\
\text { crois pas que j'avais fait assez de recherche à propos } \\
\text { de la matière donc je demandais jamais des questions } \\
\text { en classe parce que j'avais peur d'avoir l'air stupide, et } \\
\text { lorsque j'ai fait mon écriture réflexive on dirait que } \\
\text { j'avais fait une recherche et il y a avait moins de peur } \\
\text { d'avoir l'air stupide donc je demandais le plus de } \\
\text { questions possibles. }\end{array}$ & 165 \\
\hline & T2SA & $\begin{array}{l}\text { Oui, parce que par exemple, justement, j'écrivais et je } \\
\text { me questionnais sur des sujets, et ensuite je me disais : } \\
\text { ok, je comprends ça, je comprends ça, mais arrivé à } \\
\text { une nouvelle étape, celle-là je ne la comprend pas, } \\
\text { pourquoi je ne sais pas je ne la comprend juste pas, je } \\
\text { ne veux pas le lien, je ne suis pas capable de faire un } \\
\text { lien moi-même, donc là après je me disais, ça je vais } \\
\text { demander à M. Helou le lendemain, et par exemple si } \\
\text { je comprenais bien quelque chose alors je me disais je }\end{array}$ & 166 \\
\hline
\end{tabular}




\begin{tabular}{|c|c|c|c|c|}
\hline & & & $\begin{array}{l}\text { vais demander à M. Helou comment il peut rendre ça } \\
\text { plus difficile si je le comprends toujours? Pour pousser } \\
\text { (la compréhension) plus loin. }\end{array}$ & \\
\hline & & T2SB & $\begin{array}{l}\text { Bien sûr, ça nous mène à lire, réfléchir, écrire, à les } \\
\text { mettre dans des mots }\end{array}$ & 167 \\
\hline & & $\mathrm{T} 2 \mathrm{SC}$ & $\begin{array}{l}\text { Oui, par exemple je me posais des questions, si je ne } \\
\text { savais pas répondre pas ces questions-là c'est-à-dire je } \\
\text { n'ai pas très bien compris le sujet alors, ça me poussais } \\
\text { à beaucoup plus poser des questions en classe et à } \\
\text { vouloir beaucoup plus comprendre, et à savoir que } \\
\text { même si je pensais avoir compris je n'ai pas réellement } \\
\text { compris. }\end{array}$ & 168 \\
\hline \multirow{6}{*}{ 更 } & \multirow{6}{*}{$\begin{array}{l}\text { Pensez-vous que } \\
\text { l'ER était utile } \\
\text { pour mieux vous } \\
\text { préparer aux } \\
\text { discussions en } \\
\text { classe? } \\
\text { Comment? }\end{array}$} & T1SA & $\begin{array}{l}\text { Oui, je savais de quoi il parlait, je savais comme, les } \\
\text { sujets comme, par exemple comme, quand M. Helou } \\
\text { arrive, il nous pose des questions et il nous faisait } \\
\text { comme, penser sur le sujet donc on savait de quoi la } \\
\text { discussion allait être. }\end{array}$ & 169 \\
\hline & & T1SB & $\begin{array}{l}\text { Oui c'est sûr parce que sinon, avant ça je ne lisais pas } \\
\text { le manuel avant de faire le cours sur le chapitre donc } \\
\text { en lisant le manuel et en écrivant par rapport à ce que } \\
\text { j'ai lu c'est sûr que ça m'a préparé mieux à comprendre } \\
\text { ce que le prof disait }\end{array}$ & 170 \\
\hline & & T1SC & & 171 \\
\hline & & T2SA & & 172 \\
\hline & & T2SB & $\begin{array}{l}\text { Oui évidemment, je trouve que le fait qu'on l'a fait, } \\
\text { que nous avons effectué cette écriture réflexive, la } \\
\text { lecture ça nous a préparé au cours, surtout que suite à } \\
\text { certaines écritures réflexive le monsieur, il parle de } \\
\text { certaines discussions et ça nous mène, je pense la } \\
\text { plupart de la classe, à réfléchir, à participer, à débattre } \\
\text { aussi sur des points. Je trouve que c'est quand même } \\
\text { intéressant, ça nous a permis de voir d'autres } \\
\text { perspectives et à comprendre certains points. }\end{array}$ & 173 \\
\hline & & $\mathrm{T} 2 \mathrm{SC}$ & $\begin{array}{l}\text { Oui, oui, lorsque le monsieur nous posait, parce que, } \\
\text { par exemple nos pensées sur la première loi de } \\
\text { Newton est-ce que nous avions compris ça nous } \\
\text { permettait de savoir si nous avions réellement } \\
\text { compris, lorsque lui il nous pose des questions face à } \\
\text { notre compréhension, si nous avions fait des erreurs, } \\
\text { ça nous permettait de cibler cette erreur et avec l'aide } \\
\text { des autres filles ça nous permettait de faire genre, des } \\
\text { petits débats, vraiment pour clarifier nos idées, comme } \\
\text { toute la classe ensemble on établissait une certaine } \\
\text { compréhension, et on comprenait tous ensemble }\end{array}$ & 174 \\
\hline 17 & & T1SA & $\begin{array}{l}\text { Oui, parce que là, J'ai l'impression que je ne } \\
\text { comprends pas tout, avant j'étais comme, oui je }\end{array}$ & 175 \\
\hline
\end{tabular}




\begin{tabular}{|c|c|c|c|c|}
\hline \multirow{6}{*}{ 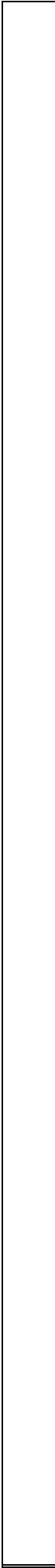 } & \multirow{6}{*}{$\begin{array}{l}\text { Est-ce que l'ER a } \\
\text { changé la façon } \\
\text { dont vous étudiez } \\
\text { ou apprendre des } \\
\text { choses? } \\
\text { Comment? }\end{array}$} & & $\begin{array}{l}\text { comprends, mais effectivement je ne comprenais pas. } \\
\text { Ça m'a permis de comprendre de plus approfondir ce } \\
\text { que je sais et ce que je ne sais pas, de comprendre, } \\
\text { d'aller plus loin. }\end{array}$ & \\
\hline & & T1SB & $\begin{array}{l}\text { Je dirais que ça a changé la manière avec laquelle } \\
\text { j'apprends des choses mais pas nécessairement la } \\
\text { manière que j'étudie parce que de toute manière je } \\
\text { lisais le manuel avant les évaluations, qu'il y a une } \\
\text { écriture réflexive ou non parce que, je veux dire je } \\
\text { résumais ce que je voyais dans le manuel et je faisais } \\
\text { tous les exercices. Donc je dirais que avec ou sans } \\
\text { l'écriture réflexive je lisais le manuel de toute manière, } \\
\text { mais est-ce que ça change la manière que j'apprends? } \\
\text { Oui, parce que ça me force à faire des liens, et puis } \\
\text { avec les liens on comprend mieux. }\end{array}$ & 176 \\
\hline & & T1SC & $\begin{array}{l}\text { D'étudier je ne crois pas que nous avons eu beaucoup } \\
\text { de test et d'évaluations après les écritures réflexives } \\
\text { pour je puisse vraiment évaluer ma façon d'étudier } \\
\text { mais de comprendre, Oui, définitivement, parce que } \\
\text { habituellement quand j'essaie de comprendre je fais } \\
\text { plus des exercices, je lis, je fais des exercices, mais ici } \\
\text { c'était plus aller en profondeur, et je crois que c'est ça } \\
\text { que la physique est }\end{array}$ & 177 \\
\hline & & T2SA & $\begin{array}{l}\text { Peut-être ça m'a aidé à apprendre et non pas à étudier } \\
\text { parce que je ne revois pas mes écritures réflexives, je } \\
\text { les écris on me les redonne pour voir ma note, mais je } \\
\text { ne les étudie pas vraiment, je pense que ça fait juste } \\
\text { améliorer mon apprentissage mais pas en mon étude. }\end{array}$ & 178 \\
\hline & & T2SB & $\begin{array}{l}\text { Je pense que l'écriture réflexive, mais, comme j'ai } \\
\text { mentionné déjà, parfois je prends connaissance de la } \\
\text { matière avant, mais ça m'a permis de les mettre, sur } \\
\text { papier, à écrire et aussi comme cerner les idées } \\
\text { importantes. }\end{array}$ & 179 \\
\hline & & $\mathrm{T} 2 \mathrm{SC}$ & $\begin{array}{l}\text { Oui j'apprenais beaucoup plus de choses parce } \\
\text { qu'avec le PowerPoint de M. Helou il fait une } \\
\text { synthèse et il rajoute des choses tandis que dans le } \\
\text { manuel c'est vraiment, ils vont plus comme expliqué } \\
\text { un exemple avec la définition et les formules il n'y a } \\
\text { pas, j'ai l'impression que le manuel va pas aller plus } \\
\text { loin, il ne va pas développé Tandis qu'avec M. Helou } \\
\text { lorsqu'il développe, lorsqu'il crée des exemples ça } \\
\text { permet de mieux comprendre }\end{array}$ & 180 \\
\hline \multirow[t]{2}{*}{18} & \multirow{2}{*}{$\begin{array}{l}\text { Si on vous } \\
\text { demandait } \\
\text { d'imaginer ce }\end{array}$} & $\begin{array}{l}\text { T1SA } \\
\end{array}$ & $\begin{array}{l}\text { Pire dans le sens que si on n'avait pas fait l'écriture } \\
\text { réflexive }\end{array}$ & 181 \\
\hline & & T1SB & $\begin{array}{l}\text { Pire, mais le cours de physique n'a jamais été... je } \\
\text { veux dire, l'année dernière j'étais une élève de M. }\end{array}$ & 182 \\
\hline
\end{tabular}




\begin{tabular}{|c|c|c|c|}
\hline \multirow[t]{5}{*}{$\begin{array}{l}\text { cours sans ER, } \\
\text { vous l'imaginerez } \\
\text { mieux ou pire? }\end{array}$} & & $\begin{array}{l}\text { Helou mais ce n'était pas des cours de physique, c'était } \\
\text { juste des cours de sciences en général mais comme, je } \\
\text { dirais que le cours serait pire car parce que personne } \\
\text { sait de quoi il s'agit avant que le cours commence, } \\
\text { mais les cours étaient quand même bien, je veux dire } \\
\text { M. Helou explique bien, la matière n'aurait pas été } \\
\text { abstraite jusqu'à la fin du cours, ça serait juste nouveau } \\
\text { pour tout le monde. }\end{array}$ & \\
\hline & T1SC & $\begin{array}{l}\text { Je pourrais l'imaginer assez facilement parce que } \\
\text { l'année passée, même avant on n'avait pas d'écriture } \\
\text { réflexive, mais les cours avec M. Helou c'était jamais } \\
\text { pas intéressant il est vraiment intéressant et passionné } \\
\text { par sa matière mais sans l'écriture réflexive ça serait } \\
\text { pire parce que je serai plus confuse et plus mélangé à } \\
\text { propos de la matière }\end{array}$ & 183 \\
\hline & T2SA & $\begin{array}{l}\text { Moi je l'imagine pire, parce que en classe tout le } \\
\text { monde avait plein de questions sur des éléments } \\
\text { vraiment simples, juste parce qu'ils n'ont pas lu la } \\
\text { matière avant. Donc M. Helou serait obligé de faire } \\
\text { par exemple } 5 \text { heures de cours sur quelque chose qui } \\
\text { pourrait juste se discuter dans une heure ou bien à la } \\
\text { place de faire une heure de cours sur quelque chose } \\
\text { qui qui est vraiment simple mais juste si on l'aurait lu } \\
\text { avant on serait questionner avant et on aurait moins de } \\
\text { questions. Je trouve que ça va nous permettre } \\
\text { d'attarder sur des choses plus importantes en classe }\end{array}$ & 184 \\
\hline & T2SB & $\begin{array}{l}\text { Je pense que sans l'écriture réflexive les discussions ne } \\
\text { seront pas aussi intéressantes ou bien pertinentes, je } \\
\text { pense que les filles seraient moins concentrées sur le } \\
\text { sujet elles comprendraient moins. Tandis qu'avec } \\
\text { l'écriture réflexive, déjà en faisant l'écriture réflexive } \\
\text { on se pose des questions et ces questions sont suscitées } \\
\text { durant la discussion et ça amine et ça vient apporter un } \\
\text { atout à la discussion, c'est plus enrichissant. }\end{array}$ & 185 \\
\hline & $\mathrm{T} 2 \mathrm{SC}$ & $\begin{array}{l}\text { Je pense que ça serait pire, pour moi, parce que le fait } \\
\text { qu'on lise le chapitre avant d'aller au cours, on savait } \\
\text { déjà de quoi il allait parler et si nous avions déjà des } \\
\text { questionnements on pourrait déjà allez les développer. } \\
\text { si par exemple, on fait la matière en classe avant de } \\
\text { lire le chapitre peut-être qu'on aurait eu des } \\
\text { questionnements plus tard et c'est mieux de } \\
\text { comprendre dès le début au lieu d'être perdu un certain } \\
\text { temps pour comprendre à la fin, comme on comprenait } \\
\text { dès le début et on pouvait comme, le suivre dans les } \\
\text { exemples qu'il faisait, c'est ça. }\end{array}$ & 186 \\
\hline & T1SA & 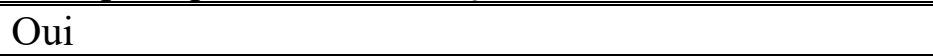 & 187 \\
\hline
\end{tabular}




\begin{tabular}{|c|c|c|c|c|}
\hline \multirow[t]{5}{*}{19} & \multirow[t]{5}{*}{$\begin{array}{l}\text { Est-ce que l'ER } \\
\text { était comme vous } \\
\text { l'attendiez? }\end{array}$} & T1SB & $\begin{array}{l}\text { Honnêtement l'écriture réflexive serait, c'était à quoi je } \\
\text { m'attendais, la seule chose c'est que, peut-être au début } \\
\text { j'avais mal compris le concept d'une écriture réflexive } \\
\text { parce que je pense que ma première note c'était } \\
\text { comme } 7 \text { ou } 8 \text { sur } 10 \text { je ne me rappelle plus, ce n'est } \\
\text { pas que c'est mauvais mais c'est juste que } 7 \text { sur } 10 \text {, je } \\
\text { sais pas, si on est noté sur notre compréhension de } \\
\text { quelque chose, c'est un peu bizarre de mettre une note } \\
\text { là-dessus, c'est quelque chose aussi que les autres } \\
\text { avaient dit aussi, qu'on devrait pas être notée pour } \\
\text { notre compréhension. Mais, je regardais la grille de } \\
\text { correction avant cette entrevue juste pour voir si c'était } \\
\text { vraiment dedans, c'est écrit genre, je pense dans le } 4 \mathrm{e} \\
\text { critère, compréhension de, je ne sais pas trop quoi. Je } \\
\text { ne veux pas dire quelque chose de faux, mais c'est vrai } \\
\text { que M. Helou ne met pas de correction nos copies de } \\
\text { l'écriture réflexive, comme si jamais il y a une } \\
\text { information qui est fausse il ne va pas dire que c'est } \\
\text { faux. }\end{array}$ & 188 \\
\hline & & T1SC & Non, elle était plus positive par rapport à mes attentes. & 189 \\
\hline & & T2SA & $\begin{array}{l}\text { Vraiment pas, moi je pensais que comme j'allais juste } \\
\text { lire puis écrire un peu n'importe quoi, comment j'avais } \\
\text { compris mais je ne comprenais pas vraiment le but au } \\
\text { début. Mais après, au fur et à mesure, je trouve que } \\
\text { plus qu'on faisait des écritures réflexives, plus que je } \\
\text { m'améliorais plus que je comprenais le principe. }\end{array}$ & 190 \\
\hline & & T2SB & $\begin{array}{l}\text { Je n'avais pas vraiment d'attente pour l'écriture } \\
\text { réflexive, mais cela ne m'a pas déçu. }\end{array}$ & 191 \\
\hline & & $\mathrm{T} 2 \mathrm{SC}$ & $\begin{array}{l}\text { Oui je m'attendais à ça, je m'attendais à ce qu'on fasse, } \\
\text { à ce qu'on écrit nos pensées, à donner des exemples et } \\
\text { tout et à beaucoup plus, dans le fond à écrire ce qu'on } \\
\text { comprenait. Je m'attendais à ça }\end{array}$ & 192 \\
\hline \multirow[t]{4}{*}{20} & \multirow{4}{*}{$\begin{array}{l}\text { Avez-vous trouvé } \\
\text { ce sujet } \\
\text { difficile/exigent? } \\
\text { Pourquoi? }\end{array}$} & T1SA & Ça dépend des chapitres & 193 \\
\hline & & T1SB & Non vraiment pas & 194 \\
\hline & & T1SC & $\begin{array}{l}\text { La plupart je n'avais pas eu beaucoup de difficultés à } \\
\text { expliquer il y avait une seule loi c'était la deuxième loi } \\
\text { parce que je trouve que c'est beaucoup plus technique } \\
\text { il n'y a plus de formules donc c'est plus difficile } \\
\text { d'expliquer ça donc, dans tes mots sans utiliser les } \\
\text { mots du manuel. }\end{array}$ & 195 \\
\hline & & T2SA & $\begin{array}{l}\text { Au début je trouvais ça difficile d'essayer de faire des } \\
\text { liens avec la vie quotidienne comme par exemple, } \\
\text { toujours trouver des idées et j'essaie de trouver des } \\
\text { idées qui étaient différentes comme pas les idées } \\
\text { classiques comme par exemple, la pomme qui tombe } \\
\text { de l'arbre, j'essaie de trouver des choses plus }\end{array}$ & 196 \\
\hline
\end{tabular}




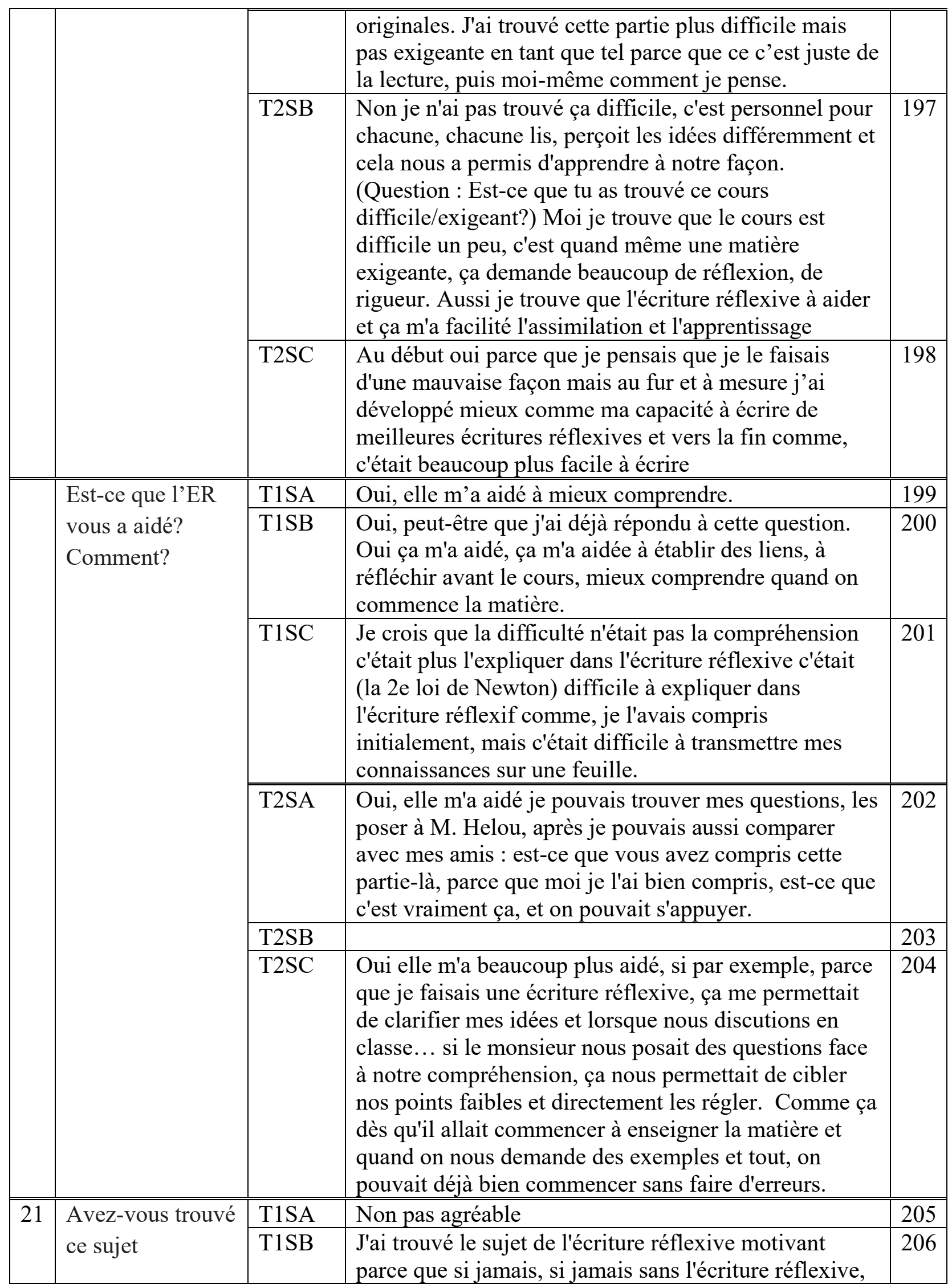




\begin{tabular}{|c|c|c|c|c|}
\hline \multirow[t]{5}{*}{ 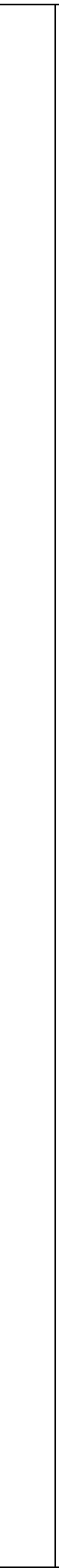 } & \multirow[t]{5}{*}{$\begin{array}{l}\text { agréable/motivan } \\
\text { t? Pourquoi? }\end{array}$} & & $\begin{array}{l}\text { tu n'aurais pas compris avec l'écriture réflexive tu as } \\
\text { déjà lu donc ça te motive parce que tu comprends } \\
\text { mieux quand tu es en classe donc tu n'as pas } \\
\text { l'impression d'entendre du chinois durant le cours de } \\
\text { physique. }\end{array}$ & \\
\hline & & T1SC & $\begin{array}{l}\text { Pour être honnête je n'aurais pas écrit des choses à } \\
\text { propos de la physique habituellement, ce n'est pas } \\
\text { quelque chose sur lequel j'écris. Mais je trouve que } \\
\text { oui (le sujet est agréable) cette année j'ai vraiment } \\
\text { découvert que la physique n'était pas ce que ce que je } \\
\text { m'attendais, c'était beaucoup plus, je sais pas, elle m'a } \\
\text { rendu plus passionnée. (T1: est-ce que tu as découvert } \\
\text { ça à cause de l'écriture réflexive?). Oui, oui }\end{array}$ & 207 \\
\hline & & T2SA & $\begin{array}{l}\text { Pas motivant, parce que c'est un travail qu'on fait seul, } \\
\text { individuel, à la maison, de la lecture, parfois les } \\
\text { chapitres sont longs donc on n'est pas motivé à les lire } \\
\text { les chapitres nécessairement, puis en plus on a même } \\
\text { pas vu la matière, donc on savait pas ça traite de quoi, } \\
\text { mais par exemple quand on est dans la lecture, là c'est } \\
\text { correcte, on a embarqué dans le sujet, on est bien, } \\
\text { quand par exemple je me disais pas : Ah j'ai hâte à } \\
\text { aller faire ce travail parce que je savais que ça allait } \\
\text { être long et de devoir penser. }\end{array}$ & 208 \\
\hline & & T2SB & $\begin{array}{l}\text { J'ai trouvé que l'idée de l'écriture réflexive } \\
\text { intéressante, comme j'ai dit, c'est une manière } \\
\text { intéressante d'apprendre et en même temps ce n'est } \\
\text { pas une tâche très très exigeante. (T2: Est-ce que tu as } \\
\text { trouvé ce cours, agréable/motivant? Pourquoi?). Je } \\
\text { dirais que c'est une branche à la science qui est très de } \\
\text { base, très intéressante, très imaginative, il faut } \\
\text { beaucoup s'imaginer. }\end{array}$ & 209 \\
\hline & & $\mathrm{T} 2 \mathrm{SC}$ & $\begin{array}{l}\text { Oui je l'avais trouvé motivante parce qu'au début ça } \\
\text { me motivait plus à développer ma compréhension, } \\
\text { lorsque je ne comprenais pas d'autres éléments, des } \\
\text { éléments qui étaient trop vagues ou trop généraux pour } \\
\text { moi je voulais plus en savoir plus et comment ça } \\
\text { s'appliquait. Avec l'écriture ça me permettait de } \\
\text { vraiment plus d'écrire mes pensées et si par exemple, } \\
\text { si je me posais des questionnements, si j'étais capable } \\
\text { de répondre et si je n'étais pas capable de répondre } \\
\text { d'une façon assez satisfaisante je pouvais donc parler } \\
\text { de ce questionnement-là à M. Helou et lui il pouvait } \\
\text { me répondre. }\end{array}$ & 210 \\
\hline 22 & $\begin{array}{l}\text { Comment } \\
\text { évaluez-vous }\end{array}$ & T1SA & $\begin{array}{l}\text { Oui, j'hésite parce que je ne sais pas si ça m'a aidé } \\
\text { pour les interros. Je sais que cela m'a aidé en classe } \\
\text { mais pour les interros, oui, ça m'a permis de }\end{array}$ & 211 \\
\hline
\end{tabular}




\begin{tabular}{|c|c|c|c|}
\hline \multirow[t]{6}{*}{$\begin{array}{l}\text { votre expérience } \\
\text { globale avec } \\
\text { l'ER? }\end{array}$} & & $\begin{array}{l}\text { comprendre la matière mais moins pour l'application, } \\
\text { Par exemple dans les problèmes, je veux dire pour moi } \\
\text { cela ne m'apporte beaucoup je veux dire pour moi. }\end{array}$ & \\
\hline & T1SB & $\begin{array}{l}\text { Oui, je la recommanderais même si le prof ne le } \\
\text { demande pas, parce que ça aide à comprendre pas } \\
\text { nécessairement de l'écrire, mais c'est vrai que c'est } \\
\text { toujours mieux de l'écrire parce que je pense que dans } \\
\text { l'apprentissage, quand tu l'entends, tu apprends mieux, } \\
\text { quand tu le lis, tu apprends mieux et quand tu l'écris tu } \\
\text { apprends encore mieux. Donc si tu peux tout combiner } \\
\text { ça fait juste mieux comprendre. Donc je le } \\
\text { recommanderais, ou au moins juste lire le chapitre } \\
\text { avant. }\end{array}$ & 212 \\
\hline & T1SC & $\begin{array}{l}\text { Oui moi personnellement j'adore l'écriture réflexive. } \\
\text { est-ce que tu recommanderais ça aux élèves de } \\
\text { secondaire } 4\end{array}$ & 213 \\
\hline & T2SA & $\begin{array}{l}\text { Personnellement, mes écritures en tant que tel, j'ai eu } \\
\text { des bonnes notes, donc je pense que c'était réussi, } \\
\text { mais même après, dans mes examens, j'avais pas } \\
\text { besoin d'autant de temps à étudier, parce que je savais } \\
\text { que j'avais bien compris la matière, je ne sais pas si ça } \\
\text { fait du sens, comme par exemple, au lieu de relire le } \\
\text { manuel avant l'interrogation puis poser maintenant } \\
\text { mes questions à M. Helou, j'avais déjà fait cette partie } \\
\text { avant, j'avais eu tout ce temps là pour analyser puis } \\
\text { retrouver des questions, quand c'est arrivé pour } \\
\text { l'examen je comprenais déjà, donc je devais juste } \\
\text { réviser rapidement puis je n'avais pas besoin du même } \\
\text { temps avant les examens. }\end{array}$ & 214 \\
\hline & T2SB & $\begin{array}{l}\text { L'écriture réflexive, c'est un bon moyen } \\
\text { d'apprentissage, c'est une manière différente que } \\
\text { d'autres manières, méthodes, et moi ça m'a aidé, et } \\
\text { puis j'ai aimé le processus, le fait de lire, assimiler les } \\
\text { informations importantes, de se poser des questions, } \\
\text { de faire des liens, ensuite l'écrire. J'ai trouvé que c'était } \\
\text { une bonne expérience et puis ça m'a aidé à } \\
\text { comprendre. }\end{array}$ & 215 \\
\hline & $\mathrm{T} 2 \mathrm{SC}$ & $\begin{array}{l}\text { Personnellement j'ai beaucoup aimé l'écriture réflexive } \\
\text { elle m'a permis de, on pourrait dire, m'enrichir dans un } \\
\text { certain sens, aussi pour m'aider à ma compréhension } \\
\text { parce que d'habitude quand M. Helou explique un } \\
\text { nouveau chapitre, qu'on n'a pas fait, qu'on avait pas vu } \\
\text { dans le manuel précédemment, au début je vais être un } \\
\text { peu perdu avec les exemples qu'il donne et tout... mais } \\
\text { avec l'écriture réflexive ça m'a permis de faire des }\end{array}$ & 216 \\
\hline
\end{tabular}




\begin{tabular}{|c|c|c|c|}
\hline & & $\begin{array}{l}\text { liens avant qu'il explique la matière et donc de cibler } \\
\text { mes points faibles }\end{array}$ & \\
\hline \multirow{6}{*}{$\begin{array}{l}\text { La } \\
\text { recommanderiez- } \\
\text { vous? Pourquoi? }\end{array}$} & "T1SA & & 217 \\
\hline & T1SB & & 218 \\
\hline & $\mathrm{T} 1 \mathrm{SC}$ & $\begin{array}{l}\text { Oui c'est utile, ça va, si tu la fais bien, ça va (1) t'aider } \\
\text { à comprendre et (2) monter ta moyenne }\end{array}$ & 219 \\
\hline & T2SA & $\begin{array}{l}\text { Oui définitivement je recommanderais ça, même dans } \\
\text { plusieurs matières je pense que ça pourrai être utile } \\
\text { même en histoire, par exemple, lire une partie puis } \\
\text { juste ressortir les éléments essentiels souvent ils } \\
\text { s'attardaient, ils décrivent, juste retirer les éléments } \\
\text { essentiels mais par exemple dans d'autres matières je } \\
\text { pense que ça ne serait pas possible mais je pense que } \\
\text { oui c'est à recommander. }\end{array}$ & 220 \\
\hline & T2SB & $\begin{array}{l}\text { Oui je recommanderais cette façon, pas juste en } \\
\text { physique mais dans d'autres matières, les autres } \\
\text { sciences, peut-être les mathématiques, l'histoire, } \\
\text { français, monde, les langues. Je trouve que ça nous } \\
\text { permet de faire des liens avec ce qu'on connaît, } \\
\text { répondre à nos questions, parce que je pense que } \\
\text { quand on se pose des questions, on déclenche cette } \\
\text { réflexion, qui peut mener loin. Aussi ça suscite des } \\
\text { discussions très intéressantes également. }\end{array}$ & 221 \\
\hline & $\mathrm{T} 2 \mathrm{SC}$ & $\begin{array}{l}\text { Oui vraiment, peut-être ça va leur faire du temps extra } \\
\text { à la maison peut-être qu'ils vont voir ça comme une } \\
\text { perte de temps, moi au début je pensais que ça allait } \\
\text { être une perte de temps mais à la fin, au fur et à } \\
\text { mesure, je trouvais que ça m'avantageait surtout parce } \\
\text { que ça développait, lorsque nous venions en classe, } \\
\text { même si on est en classe, c'est mieux d'être en classe et } \\
\text { de comprendre ce que le professeur dit au lieu d'être } \\
\text { en classe et de ne pas comprendre et d'être perdu et de } \\
\text { penser qu'on a compris mais dans le fond on n'a pas } \\
\text { compris. Lorsqu'on vient de faire des exercices si on } \\
\text { pense qu'on a compris et qu'on les a faux on va } \\
\text { vraiment savoir qu'on n'a pas vraiment compris et } \\
\text { l'écriture réflexive nous a permis de réaliser ça avant } \\
\text { que le professeur nous explique la matière }\end{array}$ & 222 \\
\hline
\end{tabular}

